INSTITUTO DE PESQUISAS ENERGÉTICAS E NUCLEARES

Autarquia Associada à Universidade de São Paulo

\title{
PROCESSOS DE SEPARAÇÃO DE MATERIAIS METÁLICOS E NÃO METÁLICOS NA RECICLAGEM DE RESÍDUOS DE PLACAS DE CIRCUITO IMPRESSO DE MICROCOMPUTADORES
}

\author{
OSCAR LUIZ FERREIRA JUNIOR
}

Dissertação apresentada como parte dos requisitos para obtenção do Grau de Mestre em Ciências na área de Tecnologia Nuclear - Materiais.

Orientadora:

Profa. Dra. Emília Satoshi Miyamaru Seo

Versão Corrigida

Versão Original disponível no IPEN

São Paulo

2013 
Dedico este trabalho a minha irmã Lourdes por tudo que ela significa para mim. 


\section{AGRADECIMENTOS}

Meus mais sinceros agradecimentos aos profissionais que ajudaram e contribuíram direta ou indiretamente para a realização deste trabalho, pois sem eles a minha trajetória teria sido muito mais difícil.

À Dra. Emilia Satoshi Miyamaru Seo, por aceitar-me como seu aluno de mestrado e pela orientação neste trabalho, aos seus ensinamentos pessoais, acadêmicos e profissionais. Agradeço a paciência e a determinação que me ajudaram a ter forças para continuar a caminhar.

Aos professores do IPEN, Dr. José Roberto Martinelli, Dra. Marycel Elena Barboza Cotrim, Dra. Vera Salvado, entre outros grandes professores que dedicaram parte de seus conhecimentos.

Ao Dr. Rubens Chiba juntamente com o Marco Andreoli, foram grandes colegas e parceiros e contribuíram e muito com suas discussões acadêmicas, apoio, incentivo, colaboração, aprendizado e amizade e por que não dizer o cuidado que tiveram para comigo, durante o desenvolvimento deste trabalho.

Ao Dr. Reinaldo Azevedo Vargas e ao Msc Everton Bonturim, Msc Silvio Luiz Ventavele da Silva, Dr. Renato Semmler e Dr. Helio Wiebeck, sempre prestativos e dispostos a ajudar.

A INBRAS-ERIEZ EQUIPAMENTOS MAGNÉTICOS E VIBRATÓRIOS LTDA. e ao Sr. Carlos Polotto.

Ao IPT Instituto de Pesquisas Tecnológicas, Centro de Tecnologias Ambientais e Energéticas, Laboratório de Resíduos e Áreas Contaminadas, ao Dr. Nestor Yoshikawa e a Camila P. Massola.

Akiko Ribeiro da Oxil , Ira Margarido e Neuci Bicov da USP CCE.

Aos profissionais, Juliana Pereira de Souza, Dr. Antonio Carlos da Silva, Victor Bridi e a Natalia pelo apoio técnico.

Meu profundo agradecimento ao Instituto de Pesquisas Energéticas e Nucleares IPEN-CNEN/SP em conjunto com a Comissão Nacional de Energia Nuclear CNEN, pelo acolhimento e infra-estrutura material, acadêmico e profissional, para minha formação e treinamento.

À Universidade de São Paulo - USP, pela oportunidade da obtenção do título de Mestre em Ciências, naquela que é considerada a maior e melhor universidade do país. 
NULLA TENACI INVIA EST VIA Para os tenazes nenhum caminho é impossível. 


\title{
PROCESSOS DE SEPARAÇÃO DE MATERIAIS METÁLICOS E NÃO METÁLICOS NA RECICLAGEM DE RESÍDUOS DE PLACAS DE CIRCUITO IMPRESSO DE MICROCOMPUTADORES
}

\author{
Oscar Luiz Ferreira Junior
}

RESUMO

Com a aprovação da Política Nacional de Resíduos Sólidos, a política de sustentabilidade tende ao reaproveitamento de resíduos, em seu ciclo ou destinação final ambientalmente adequada. Neste contexto, são apresentados neste trabalho, estudos do processo de separação de materiais metálicos e não metálicos encontrados em placas de circuito impresso de microcomputadores e a caracterização dos elementos químicos presentes. Para isto efetuou-se a trituração primária (moagem) das placas de circuito impresso, classificação granulométrica, separação de elementos metálicos e não metálicos utilizando separadores, magnético e eletrostático, separação gravimétrica com o uso de clorofórmio e bromofórmio. Para caracterização dos elementos metálicos e não metálicos, foram utilizadas as técnicas de Espectrometria de fluorescência de Raios $X$ e Espectrometria de infravermelho. Os separadores eletrostático e eletromagnético não foram efetivos na separação de placas de circuito impresso para granulometrias inferiores a 9 Mesh. A separação dos elementos metálicos e não metálicos das amostras com granulometrias inferiores a 9 Mesh, teve eficiência parcial utilizando o clorofórmio, mas mostrou-se efetiva com a utilização do bromofórmio. Embora a separação gravimétrica, não tenha sido efetiva, as amostras foram caracterizadas. Para obter uma melhor separação dos elementos presentes na amostra de não metálicos, procedeu-se a trituração secundária (moagem) desta amostra, resultando na desagregação e separação efetiva. 


\title{
SEPARATION PROCESSES OF METAL MATERIALS AND NON \\ METAL RECYCLING ON WASTE OF PRINTED CIRCUIT BOARDS \\ MICROCOMPUTERS
}

\author{
Oscar Luiz Ferreira Junior
}

\begin{abstract}
With the approval of the National Solid Waste Policy, the sustainability policy tends to refer to the reuse of waste materials in its cycle or final destination, environmentally right. In this context, it is introduced in this work a study of metallic and nonmetallic materials separation, found in printed circuit boards of microcomputers and present chemical elements characterization. For this purpose it was performed the primary crushing (grinding) of printed circuit boards, particle size classification, separation of metallic and non-metallic elements by using magnetic and electrostatic separators, gravimetric separation using chloroform and bromoform. For characterization of metallic and nonmetallic elements, were used Spectrometry X-ray fluorescence and infrared spectrometry techniques. The electrostatic and electromagnetic separators were not effective in the separation of printed circuit boards for grain sizes below 9 Mesh. The separation of metallic and non-metallic elements of the samples with particle sizes less than 9 Mesh, had partial efficiency using chloroform, but was effective with the use of bromoform. Although the gravimetric separation, has not been effective, the characterized samples were. In order to get better separation of the elements present in non metallic samples it was made the secondary crushing (grinding) of this sample resulting in the breakdown and effective separation.
\end{abstract}




\section{SUMÁRIO}

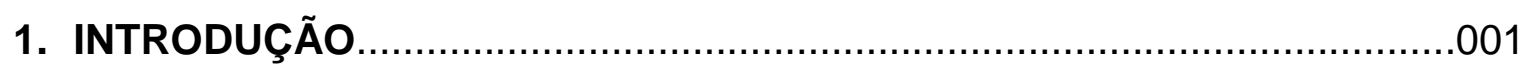

1.1 Resíduo eletroeletrônico e seus componentes......................................002

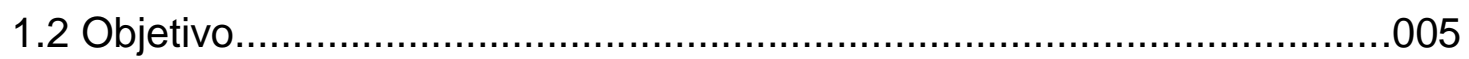

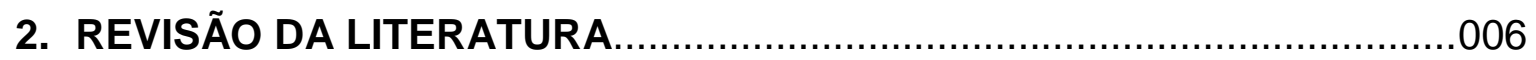

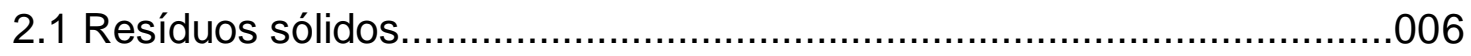

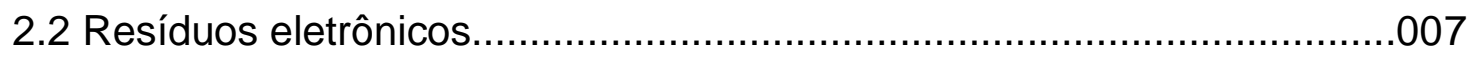

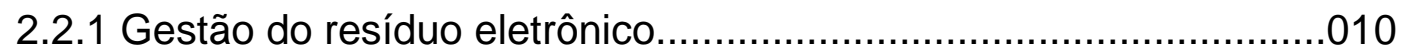

2.2.2 Gerenciamento do resíduo eletrônico............................................011

2.3 Métodos de tratamento de placas de circuito impresso...........................012

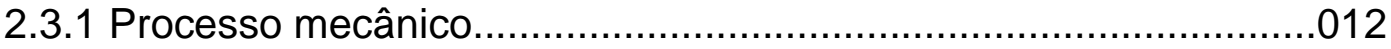

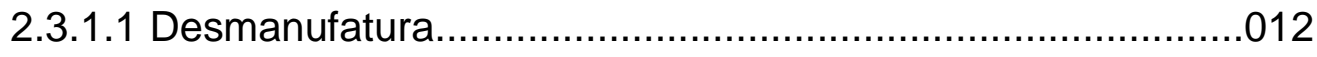

2.3.1.2 Trituração (moagem) .................................................... 012

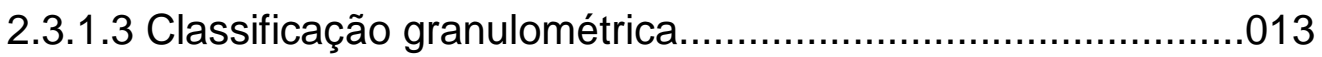

2.3.1.4 Separação magnética........................................................

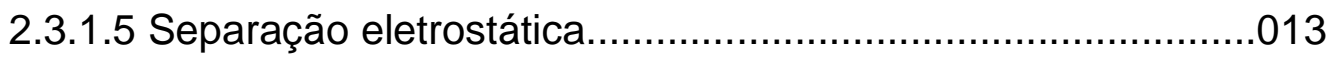

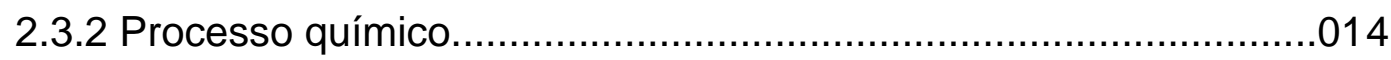

2.3.2.1 Separação em meio denso....................................................

2.4 Cenários mundiais do resíduo eletrônico................................................014

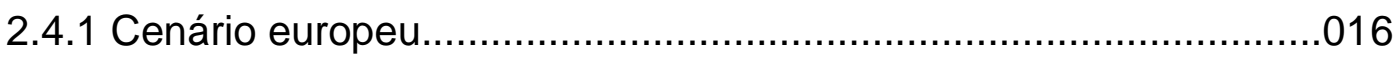

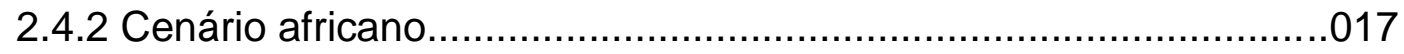

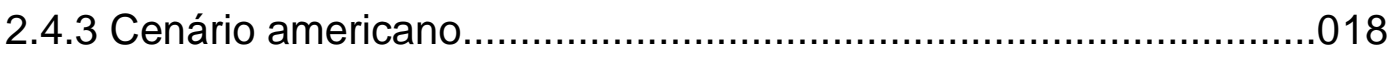

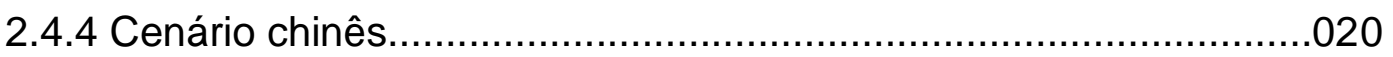

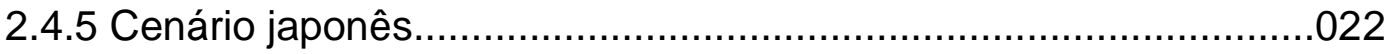

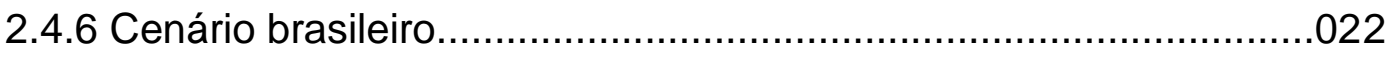

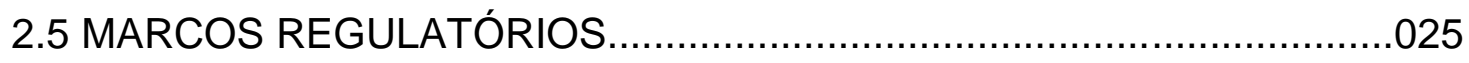

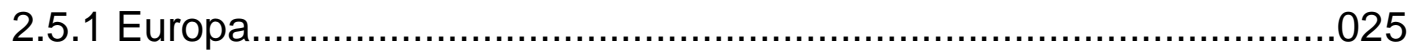

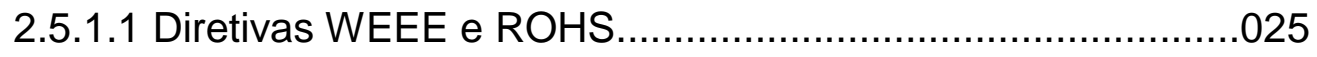

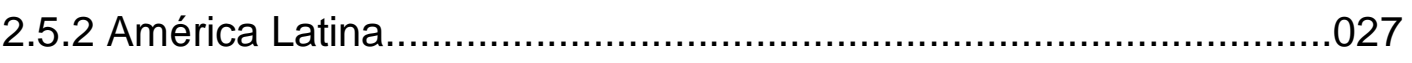

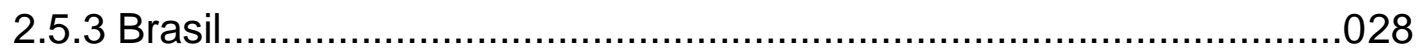


3. MATERIAIS E MÉTODOS.

3.1 Materiais.

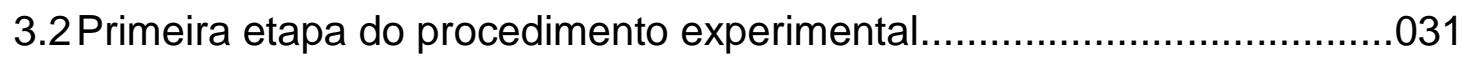

3.2.1 Etapa de Trituração Primária (moagem) ........................................033

3.2.2 Etapa de Classificação Granulométrica......................................033

3.2.3 Etapa de separação por densidade em mesa vibratória................034

3.2.4 Etapa de separação física (magnética e eletrostática)..................035

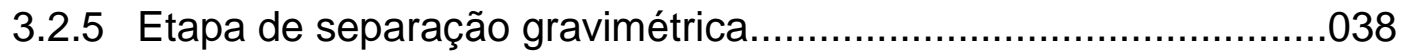

3.3Segunda etapa do procedimento experimental................................... 040

3.3.1 Etapa de Trituração Secundária (moagem).................................040

3.3.2 Etapa de separação gravimétrica..................................................

3.3.3 Etapa de caracterização do material polimérico............................042

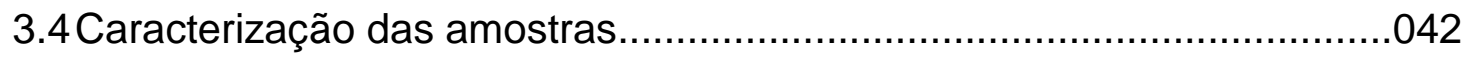

3.4.1 Espectrometria de fluorescência de Raios X.............................042

3.4.2 Espectrometria de infravermelho com (FT-IR) ...........................044

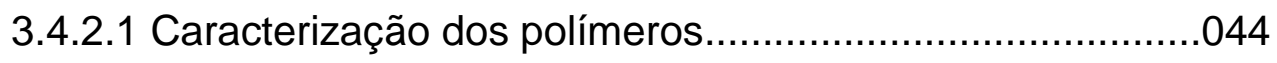

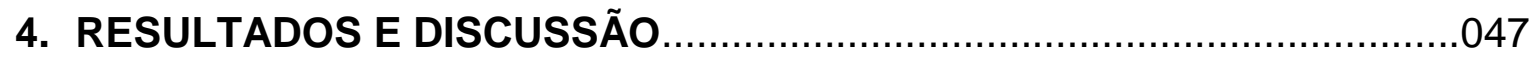

4.1 Moagem e Classificação Granulométrica..............................................

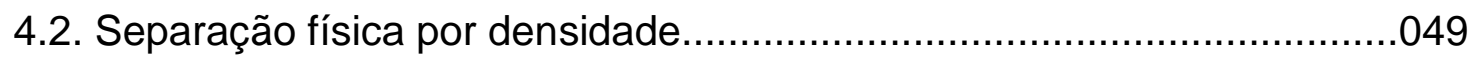

4.3. Separação Magnética e Eletrostática.................................................. 051

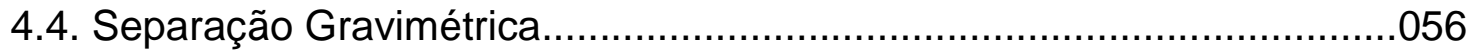

4.4.1 Separação por densidade com solução de Clorofórmio...................056

4.4.2 Separação por densidade com solução de Bromofórmio.................060

4.4.3 Separação por densidade com solução de bromofórmio após

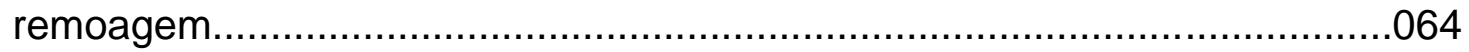

4.5. Caracterização de polímeros por meio da Espectrometria de Infravermelho

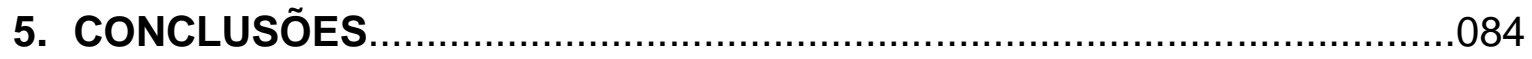

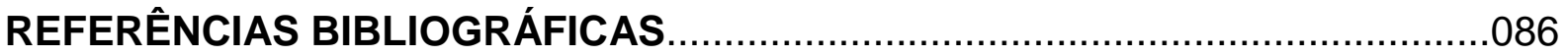

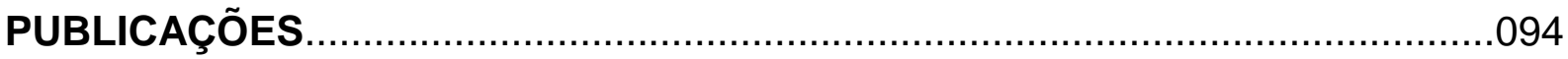




\section{LISTA DE TABELAS}

Tabela 1.1 - Estimativa dos resíduos eletroeletrônicos produzidos e coletados anualmente em alguns países. .002

Tabela 3.1 - Abertura das malhas das peneiras. .033

Tabela 3.2 - Condições experimentais do processo de separação utilizando os separadores magnético e eletrostático. 037

Tabela 3.3 - Densidades de alguns líquidos .039

Tabela 4.1 - Quantidade mássica após a classificação granulométrica. .048

Tabela 4.2 - Densidades dos elementos químicos presentes nas amostras 9,12 e 20 Mesh. .050

Tabela 4.3 - Quantidade mássicas das frações (9, 12 e 20 Mesh) das placas de circuito impresso retidas nos coletores da mesa vibratória. 051

Tabela 4.4 - Quantidade da fração metálica com granulometria 9 Mesh, resultante do processo de separação física. 052 Tabela 4.5 - Condições empregadas na separação magnética e eletrostática... 053

Tabela 4.6 - Caracterização química e quantidades dos elementos químicos presentes na amostra de granulometria 9 Mesh. .054

Tabela 4.7 - Classificação magnética dos elementos presentes na amostra com granulométrica de 9 Mesh. .055

Tabela 4.8 - Resultados dos testes gravimétricos para as granulometrias 12 Mesh ao Fundo (prato). 056

Tabela 4.9 - Elementos químicos presentes na amostra da granulometria 60 Mesh. 057

Tabela 4.10 - Elementos químicos presentes na amostra da granulometria 150 Mesh. .058

Tabela 4.11 - Elementos químicos presentes na amostra da granulometria Fundo (prato) 059

Tabela 4.12 - Resultados dos testes gravimétricos para as granulometrias 12 Mesh ao Fundo (prato). .060

Tabela 4.13 - Elementos químicos presentes na amostra da granulometria 60 Mesh. .061

Tabela 4.14 - Elementos químicos presentes na amostra da granulometria 150 Mesh. .062

Tabela 4.15 - Elementos químicos presentes na amostra da granulometria Fundo (prato) .063 
Tabela 4.16 - Resultados dos testes gravimétricos para as granulometrias 60, 150

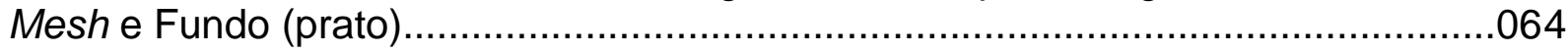

Tabela 4.17 - Elementos químicos presentes na amostra da granulometria 60

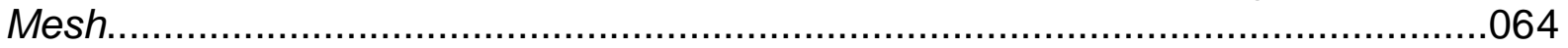

Tabela 4.18 - Elementos químicos presentes na amostra da granulometria 150 Mesh. .065

Tabela 4.19 - Elementos químicos presentes na amostra da granulometria Fundo (prato) .066

Tabela - 4.20 Elementos químicos presentes nas amostras da granulometria 60 Mesh. 067

Tabela - 4.21 Elementos químicos presentes nas amostras da granulometria 150 Mesh. .069

Tabela - 4.22 Elementos químicos presentes nas amostras da granulometria Fundo (prato). .070

Tabela 4.23 - Bandas referenciadas na granulometria 60 Mesh................................075

Tabela 4.24 - Bandas referenciadas na granulometria 150 Mesh.........................077

Tabela 4.25 - Bandas referenciadas na granulométrica Fundo (prato)....................080

Tabela 4.26 - Bandas referenciadas no espectro da resina epóxi. .081 


\section{LISTA DE FIGURAS}

Figura 2.1 - Resíduo eletrônico entre alguns países emergentes da America

Latina 024

Figura 3.1 - Placas de circuito impresso descaracterizadas.

Figura 3.2 - Fluxograma esquemático do procedimento experimental 032

Figura 3.3 - Mesa Vibratória .034

Figura 3.4 - Separador magnético .035

Figura 3.5 - Separador eletrostático. .036

Figura 3.6 - Mecanismo de geração de fluorescência de Raios X.........................043

Figura 3.7 - Estrutura química do diglicidil éter de bisfenol A (DGEBA)..................045

Figura 3.8 - Espectrômetro com transformada de Fourier .046

Figura 4.1 - Classificação granulométrica das placas de circuito impresso moídas. 047

Figura 4.2 - Material em formato lamelar nos rifles da mesa vibratória 049

Figura 4.3 - Esquema para interpretação de espectros de substâncias orgânicas na região do infravermelho. .073

Figura 4.4 - Espectro de FT-IR do material sobrenadante para a granulometria 60 Mesh. .074

Figura 4.5 - Espectro de FT-IR do material sobrenadante para a granulometria 150 Mesh. .076

Figura 4.6 - Espectro de FT-IR do material sobrenadante para a granulométrica Fundo (prato).... .079

Figura 4.7 - Espectro de FT-IR da resina epóxi. .081

Figura 4.8 - Espectro de FTIR da resina epóxi e do material sobrenadante para a faixa 60 Mesh. 082

Figura 4.9 - Espectro de FTIR da resina epóxi e do material sobrenadante para a faixa 150 Mesh. .083

Figura 4.10 - Espectro de FTIR da resina epóxi e do material sobrenadante da granulometria Fundo (prato). .084 


\section{LISTA DE ABREVIATURAS}

ABINEE Associação Brasileira da Indústria Elétrica e Eletrônica

ABNT Associação Brasileira de Normas Técnicas

ABRELPE ASSOCIAÇÃO BRASILEIRA DAS EMPRESAS DE LIMPEZA PÚBLICA E RESÍDUOS ESPECIAIS

ANVISA Agência Nacional de Vigilância Sanitária

AT Advanced Technology - Tecnologia Avançada

ATX Advanced Technology eXtended - Tecnologia Avançada Estendida

CONAMA Conselho Nacional do Meio Ambiente

EDS Espectroscopia de raios $\mathrm{X}$ por energia dispersiva

EDXRF Espectrometria de Fluorescência de Raios X por dispersão de energia

EMPA Instituto pesquisa suíço de ciência dos materiais

EPA Agência de Proteção Ambiental americana

EU União Européia

EUA Estados Unidos da América

e-lixo Lixo eletrônico (resíduo)

FRX Fluorescência de Raios $\mathrm{X}$

FT-IR Espectroscopia de infravermelho com transformada de Fourier

HP Hewlett-Packard

IBM International Business Machines

ICP-OES Espectrometria de emissão óptica por plasma de argônio

IDRC International Development Research Centre

IPEN Instituto de Pesquisas Energéticas e Nucleares

IPT Instituto de Pesquisas Tecnológicas do Estado de São Paulo

NBR Norma Brasileira

OECD Organisation for Economic Co-operation and Development

PBB Bifenilos Polibromados 


$\begin{array}{ll}\text { pH } & \text { Potencial hidrogênionico } \\ \text { PC board } & \text { Placas de Circuito Impresso } \\ \text { PCs } & \text { Computadores pessoais } \\ \text { PNRS } & \text { Política Nacional de Resíduos Sólidos } \\ \text { PNUMA } & \text { Programa das Nações Unidas para o Meio Ambiente } \\ \text { Picking-cereja } & \text { Parte comercializável - lucrativa } \\ \text { REEE } & \text { Resíduos de Equipamentos Elétricos e Eletrônicos } \\ \text { RAEE } & \text { Resíduos de Aparelhos Elétricos Eletrônicos } \\ \text { RPM } & \text { Rotações por minuto } \\ \text { RoHS } & \text { Restrições de Substâncias Perigosas } \\ \text { RSU } & \text { Resíduos sólidos urbanos } \\ \text { SWICO } & \text { Swiss Association for Information, Comunication and Organisation Technology } \\ \text { TI } & \text { Tecnologia de Informação } \\ \text { TIC } & \text { Tecnologia de Informação e Telecomunicações } \\ \text { TVs } & \text { Televisores } \\ \text { WEEE } & \text { Waste in Electronics and Electrical Equipment }\end{array}$




\section{LISTA DE SÍMBOLOS}

$\begin{array}{ll}\mathrm{cm} & \text { Centímetro } \\ \mathrm{g} & \text { Grama } \\ \mathrm{L} & \text { Litro } \\ \mathrm{mg} & \text { Miligrama } \\ \mathrm{cm}^{-1} & \text { Número de onda } \\ \% & \text { porcentagem } \\ \text { in } & \text { polegada }=25,40 \mathrm{~mm} \\ \mu \mathrm{m} & \text { micrometro }=0,001 \mathrm{~mm}\end{array}$




\section{INTRODUÇÃO}

A intensa industrialização, o advento de novas tecnologias, o adensamento populacional em centros urbanos e a diversificação do consumo de bens e serviços produzem grande volume de resíduos, que se transformam em graves problemas urbanos. Essa situação é decorrente do (mau) hábito de descartar os inservíveis de qualquer forma, o que demonstra falta de educação e consciência, tornando o gerenciamento oneroso e complexo.

Como resultado desse novo cenário, observa-se ao longo dos últimos anos, mudanças significativas nas características desses resíduos. Os produtos eletrônicos têm gerado crescente volume de resíduo e já constituem parcela significativa do volume a ser gerido. Um dos maiores desafios com que se defronta a sociedade moderna é o equacionamento da questão do resíduo urbano, sobretudo nos países em desenvolvimento.

As indústrias de manufatura, por exemplo, para atingirem seus objetivos e metas de produção utilizam processos e tecnologias que geram em suas cadeias produtivas, produtos e subprodutos passíveis de comprometer o meio ambiente e a saúde da população.

Um bom exemplo é o desastre ambiental ocorrido em Minamata no Japão, identificado em meados da década de 1950 (HOGAN, 2007), devido a contaminação de centenas de pessoas por mercúrio, causada por uma indústria que lançava dejetos contendo mercúrio na baía de mesmo nome, desde a década de 1930. Outro exemplo foi o ocorrido em Love Canal situado próximo às cataratas do Niagara nos Estados Unidos, que serviu de depósito de resíduos orgânicos diversos por muitos anos (HOGAN, 2007).

Esses fatos desastrosos despertaram na população 0 interesse pela conservação do meio ambiente. Encontros como a Conferência das Nações Unidas sobre Meio ambiente (ECO 92), demonstraram que a sociedade vem exigindo das indústrias de manufatura que se comprometam com um desenvolvimento econômico ambientalmente sustentável, que os governos e órgãos de fiscalização imponham 
maior rigor, ao cumprimento das legislações, normas técnicas e adoção de padrões de qualidade e gerenciamento tais como a ISO 14000.

Questões, tais como: geração diária de grande volume de resíduos, destinação correta para cada tipo de resíduo, identificação do impacto causado pelos resíduos descartados e a redução de custos são assuntos constantes da pauta de programas de gerenciamento de resíduos pelas empresas conscientes.

\subsection{RESÍDUO ELETRÔNICO E SEUS COMPONENTES}

Sem dúvida nenhuma, as primeiras ações a serem tomadas são o controle e a minimização da geração dos resíduos, porém, para resíduos da indústria eletrônica a maior fração é constituída por equipamentos elétricos e eletrônicos no fim de sua vida útil.

A tabela 1.1 mostra a estimativa de geração de resíduos da indústria eletrônica de alguns países.

Tabela 1.1 - Estimativa dos resíduos eletroeletrônicos produzidos e coletados anualmente em alguns países.

\begin{tabular}{l|l|l}
\hline Países & $\begin{array}{l}\text { Resíduos produzidos } \\
\text { (bilhões de ton/ano) }\end{array}$ & $\begin{array}{l}\text { Resíduos coletados } \\
\text { (bilhões de ton/ano) }\end{array}$ \\
\hline Estados Unidos (2002) & 2.125 & - \\
\hline Alemanha (2004) & 1.100 & 104 \\
\hline Reino Unido (1998) & 900 & - \\
\hline Dinamarca (1997) & 118 & 17 \\
\hline Suíça (2003) & 66 & - \\
\hline Tailândia (2003) & 60 & - \\
\hline$\left(^{\star}\right)$ Equipamentos elétricos não estão incluídos \\
$\left(^{* *)}\right.$ Somente alguns REEE estão considerados \\
Fonte: Agências Ambientais Nacionais e/ou especialistas dos países consultados
\end{tabular}


Nessa amostragem a porcentagem estimada de resíduos coletados em países como Alemanha e Dinamarca, são respectivamente 9\% e 14\%.

A indústria eletrônica é um segmento de produção acelerada devido a constante renovação e evolução tecnológica, o que the confere maior potencial na geração de fluxo de resíduos.

$O$ uso de equipamentos elétricos e eletrônicos tem aumentado exponencialmente nessas duas últimas décadas, especialmente devido ao crescimento das tecnologias de informação.

Vale mencionar que é preciso definir regras e princípios rígidos para geração, acondicionamento, coleta, transporte, tratamento e destinação final dos resíduos eletrônicos, responsabilizando as empresas partícipes dos processos de fabricação e comercialização pelo recolhimento e destruição dos equipamentos descartados. Tal conduta não resolve por completo o problema, mas monitorar ajuda a manter o controle, facilitando o gerenciamento.

Caracterizam-se por tipos de resíduos eletrônicos, placas de circuito impresso, aparelhos de telefonia móvel, pilhas, baterias, televisores, monitores, entre outros.

Tais resíduos, usualmente conhecidos como Resíduos de Aparelhos Elétricos Eletrônicos são denominados popularmente no Brasil como, sucata de informática, lixo eletrônico, e-resíduos ou lixo tecnológico, em inglês, de Waste Electrical and Electronic Equipment (WEEE), Electronic waste ou e-Waste.

Entre os tipos de resíduos eletrônicos, será o foco deste trabalho as placas de circuito impresso. Essas placas são constituídas de resina (matriz polimérica) e compósitos (que é o resultado da combinação de dois ou mais materiais distintos em suas propriedades físicas), além de uma série de metais e ligas o que podem tornarse uma fonte poluidora muito significativa.

Devido à grande diversidade de linhas de produtos, as indústrias foram distribuídas em dez subsetores: Automação Industrial, Componentes Elétricos e Eletrônicos, Equipamentos Industriais, Geração, Transmissão e Distribuição de Energia Elétrica, Informática, Material Elétrico de Instalação, Serviço de Manufatura em Eletrônica, Sistemas Eletroeletrônicos Prediais, Telecomunicações e Utilidades Domésticas Eletroeletrônicas (ABINEE, 2013). 
O REEE ou WEEE é um resíduo diferente do resíduo tradicional. O descarte doméstico caracterizado como um resíduo tradicional, recebe normalmente um tratamento, realizado por processos convencionais de disposição em valas de aterros sanitários, porém o tratamento de WEEE necessita de maior cuidado, devido às substâncias altamente tóxicas contidas neste tipo de resíduo.

Componentes como microprocessadores, placas de circuito integrado e componentes para circuitos eletrônicos contêm, metais tóxicos como Antimônio, Berílio, Chumbo, Estanho, Prata, Mercúrio e Cádmio (BIZZO, 2007 a).

Segundo a definição da norma ABNT NBR 10.004, o resíduo sólido tradicional nos estados sólido ou semi-sólido resulta de atividades de origem industrial, doméstica, hospitalar, comercial, agrícola, de serviços de varrição.

O relatório Final de 20 de Julho de 2009 gerado pela PNUMA, sobre os recursos da reciclagem de WEEE, contém uma análise sobre o potencial das tecnologias inovadoras no mercado de reciclagem. Observa que não basta simplesmente a instalação de usinas de reciclagem ou a transferência de tecnologia ambientalmente sustentáveis e eficazes para um país. Não basta ter um potencial de mercado, tê-lo não significa necessariamente que uma operação pode ser executada de uma forma auto-suficiente. Qualquer esforço para resolver o problema do WEEE, sem levar em conta as interligações sobre aspectos sociais, ambientais e econômicos, isso é provavelmente fadado ao fracasso. Serão necessários também investimentos consideráveis, e muitos estudos para o desenvolvimento de tecnologias, ou um conjunto de processos que utilizem resíduos eletrônicos e resultem em melhor reaproveitamento dos materiais empregados. Para atender a esta necessidade é preciso conhecer todas as sequências do processo que se inicia quando o aparelho é considerado obsoleto, tais como: a logística de coleta, o armazenamento, a desmanufatura, o tratamento e a reutilização. Ao estudar a recuperação de materiais utilizados em equipamentos eletrônicos, indiretamente, isso contribui para o estudo de não agressão ao meio ambiente (UNEP, 2009).

No caso dos microcomputadores, tais estudos são particularmente importantes, devido ao alto custo dos materiais utilizados na fabricação de 
componentes de circuitos eletrônicos, tais como ouro, prata, paládio, cobre, estanho, gálio, índio (KUEHR, 2003).

Conforme Vianna (2007), pesquisadores da Unicamp realizaram o processo de lixiviação em placas de circuito impresso de computadores, obtendo o seguinte resultado: Cádmio de $22 \mathrm{mg} / \mathrm{L}$ (limite de $0,5 \mathrm{mg} / \mathrm{L}$ ) e $133 \mathrm{mg} / \mathrm{L}$ de Chumbo (limite de $1 \mathrm{mg} / \mathrm{L}$ ), para tal tomaram como base a norma NBR 10.004:2004.

Andrade (2002) registra que um computador é composto por $40 \%$ de plástico, $37 \%$ de metais, $5 \%$ de dispositivos eletrônicos, $1 \%$ de borracha e $17 \%$ de outros produtos. Deste total, $94 \%$ são recuperáveis, com alto potencial de reciclagem.

Segundo Salinas (2008), as informações disponíveis sobre a contaminação e os problemas ambientais, produzidos pelo material utilizado na fabricação de computadores são poucas. Como também são reduzidas aquelas relativas a gestão dos resíduos gerados por este tipo de equipamento eletrônico, quando chega ao fim da vida útil.

Conforme o estudo dos analistas da empresa Wipro Product Stractegy, o grande volume de vendas de computadores nos Estados Unidos, que se projeta no curto prazo para estes equipamentos e o prazo para estes tornarem-se obsoletos é em média de 3 anos (MILLER, 2010).

Dada a grande importância dos materiais presentes nas placas de circuito impresso mother board de microcomputadores, este trabalho busca contribuir no desenvolvimento do processo de separação de materiais metálicos e não metálicos e na identificação dos elementos químicos presentes.

\subsection{OBJETIVO}

O presente trabalho tem por objetivo, avaliar os processos de separação dos materiais metálicos e não metálicos, presentes nas placas de circuito impresso (placa-mãe, mother board). Pretende verificar a efetividade dos processos de separação física e química e caracterizar os elementos químicos metálicos e não metálicos, contidos nas placas de circuito impresso. 


\section{REVISÃO DA LITERATURA}

\subsection{Resíduos sólidos}

A norma ABNT NBR 10004: 2004; tem como objetivo a classificação dos resíduos sólidos quanto a seus riscos potenciais ao meio ambiente. A classificação de resíduos envolve a identificação do processo ou atividade que lhe deu origem, de seus constituintes (ABNT, 2004).

Portanto conhecer as características físicas e químicas do resíduo, assim como suas tendências futuras são parâmetros possibilitam calcular a capacidade, o tipo de coleta e tipo de tratamento e o destino final.

O volume torna-se importante para dimensionar os locais de descarga, a composição serve para dimensionar as potencialidades econômicas do resíduo, a classificação dos resíduos quanto ao risco à saúde publica e ao meio ambiente, subsidiando informações para a escolha do melhor e mais adequado sistema de tratamento e disposição final.

Segundo a norma NBR 10004:2004; os resíduos sólidos são classificados em dois grupos - perigosos (Classe I) e não perigosos (Classe II), sendo ainda este ultimo grupo subdividido em não inerte (Classe IIA) e inerte (Classe IIB) (ABNT, 2004).

A norma NBR 10004:2004; aplica a definição para resíduos sólidos:

Resíduos nos estados, sólido e semi-sólido, que resultam de atividades de origem industrial, doméstica, hospitalar, comercial, agrícola, de serviços e de varrição. Ficam incluídos nesta definição os lodos provenientes de sistemas de tratamento de água, aqueles gerados em equipamentos instalações de controle da poluição, bem como determinados líquidos cujas particularidades tornem inviável o seu lançamento na rede pública de esgotos ou corpos de água, ou exijam para isso soluções técnicas e economicamente inviáveis em face à melhor tecnologia disponível. No item 3.8.1 são apresentados detalhes sobre a norma NBR 10004: 2004. 


\subsection{Resíduos eletrônicos}

No discurso comum nos países industrializados, "resíduo eletrônico" é considerado como sendo um dispositivo eletroeletrônico, que não tem mais valor (econômico) para o usuário. No entanto, quando um dispositivo eletroeletrônico, torna-se inútil para o usuário principal pode ainda ter um valor para os próximos detentores deste equipamento, isto é para o próximo usuário, aquém este dispositivo é destinado, nas as condições apresentadas no momento, ainda tem serventia.

O proprietário pode vendê-lo e então se desenvolve um processo em cadeia no qual é reutilizado, recuperado ou definitivamente descartado.

Ao atingir o estágio de definitivamente descartado é por que o equipamento perdeu seu valor econômico, sua utilidade e sua funcionalidade, tornando-se descartável e consequentemente, isto, o caracteriza como "resíduo eletrônico" definido por intermédio do termo WEEE (WIDMER et al., 2005).

O resíduo eletrônico é uma questão controversa discutida em uma escala global e apresenta vários riscos e oportunidades. Destaca-se como oportunidade a reciclagem adequada do resíduo eletrônico que é "claramente vantajosa a partir de um ponto vista ambiental", como provado em um estudo realizado por (HISCHIER et al., 2005).

Várias entidades e autores têm realizado tentativas para empregar o termo que melhor defina resíduos eletrônicos.

Uma seleção de definições e as diferentes categorias de resíduo eletrônico são padronizadas pela Diretiva WEEE da UE (Parlamento Europeu e do Conselho da União Européia, 2003). O resíduo eletrônico é referido como "qualquer aparelho com uma fonte de energia elétrica que atingiu o seu fim-de-vida", como é definido pela Organização para a Cooperação Econômica e Desenvolvimento da OECD (2010).

Outra perspectiva de resíduo eletrônico é valor contido em suas matériasprimas valiosas, incluindo muitos metais preciosos. Estes metais podem ser 
recuperados com diferentes técnicas existentes. Assim, a reciclagem do resíduo eletrônico pode se tornar um negócio lucrativo, para quem detém a técnica dos processos de reciclagem.

O resíduo eletrônico é composto por várias substâncias entre as quais podem conter metais pesados e algumas substâncias tóxicas. De acordo com Widmer et al. (2005), os fatores de riscos, são representados pela presença de chumbo, mercúrio, arsênio, cádmio, selênio, cromo hexavalente e retardadores de chama utilizados no revestimento de fios e cabos os bifenilos policlorados e polibromados, que, se incinerados, tomam a forma de emissões de dioxina. Todas essas substâncias perigosas podem significar uma ameaça à saúde humana e ao meio ambiente a menos que sejam descartadas seguindo critérios adequados. Conforme Zumbuehl (2006, p. 11), "Cerca de 70\% dos metais pesados (incluindo o mercúrio e cádmio) encontrado nos aterros vêm de equipamentos eletrônicos". De acordo com um relatório da Comissão Européia, cerca de $40 \%$ do chumbo encontrado em aterros são de origem de equipamentos eletrônicos (ZUMBUEHL, 2006).

Devido às tendências de expansão do uso de itens no setor de TIC, a dissipação de substâncias tóxicas e até mesmo de materiais valiosos está ocorrendo, devido à distribuição e a eliminação de equipamentos e componentes eletrônicos, sem que medidas eficazes sejam tomadas.

A Associação Brasileira da Indústria Elétrica e Eletrônica - ABINEE, representa no Brasil o setor eletroeletrônico e tem como associadas indústrias nacionais e internacionais de diversos portes e segmentos, para as quais fornece suporte e subsídios para o desenvolvimento de suas atividades. Devido à grande diversidade de linhas de produtos, essas indústrias foram distribuídas em dez subsetores: Automação Industrial, Componentes Elétricos e Eletrônicos, Equipamentos Industriais, Geração, Transmissão e Distribuição de Energia Elétrica, Informática, Material Elétrico de Instalação, Serviço de Manufatura em Eletrônica, Sistemas Eletroeletrônicos Prediais, Telecomunicações e Utilidades Domésticas Eletroeletrônicas (ABINEE, 2011). O setor de Tecnologia de Informação e Telecomunicações, (TIC) é um dos mais dinâmicos da atualidade, sendo que em 
2004, mais de 180 milhões de computadores pessoais, (PCs) foram vendidos no mundo, nesse mesmo ano 2004, cerca de 100 milhões de PCs obsoletos entraram no fluxo de resíduos e foram reciclados para a recuperação de materiais ou finalmente eliminados (HILTY, 2005).

A placa de circuito impresso do tipo placa-mãe, (motherboard), é a principal placa de um computador pessoal, é por meio desta placa que todos os outros componentes de um computador se comunicam, existem diversos modelos e fabricantes, recebem denominações diferentes, os nomes podem mudar a cada evolução e mudança de versão, AT (Advanced Technology - Tecnologia Avançada), ATX (Advanced Technology eXtended - Tecnologia Avançada Estendida) e variando a denominação conforme o fabricante, RTX, LPX ,ITX.

A miniaturização contínua dos componentes eletrônicos, de acordo com a Lei de Moore (Em 1965, o co-fundador da Intel Gordon Moore previu que o número de transistores dos chips iria dobrar a cada 2 anos), em conformidade com as tendências tecnológicas, poderia vir a ser uma das soluções na resolução dos problemas. Contudo a experiência mostra que a miniaturização dos dispositivos é normalmente neutralizada por um número crescente de dispositivos produzidos.

Por exemplo, a redução considerável do peso médio de um telefone móvel

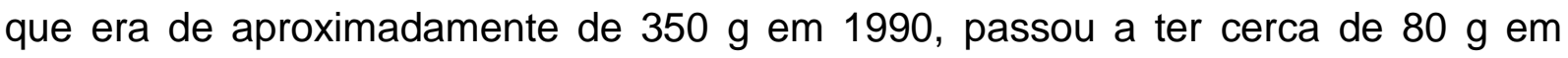
2005 , o que corresponde a uma redução de $80 \%$ do peso, em referencia ao peso inicial, foi acompanhada por um aumento, em 8 vezes no número de assinantes com aparelhos móveis (HILTY, 2005).

Tem sido tema em vários fóruns de discussão, a eliminação da fração de plástico, utilizado nos aparelhos eletroeletrônicos, o tratamento térmico que deve ser empregado aos resíduos eletrônicos, quais rotas são utilizadas para o descarte dos resíduos e as diferentes formas de gestão, incluindo o material para reciclagem química.

Em relação a um dos tipos de plásticos empregados, em algumas das partes do computador, pode-se, citar os compostos orgânicos utilizados para retardar 
chamas. Sobre isto há poucas informações disponíveis sobre as classes de compostos utilizados para esse fim. Também não há nenhum método de análise padronizado para o procedimento de limpeza (recuperação) para essa classe de composto plástico, que pode sofrer reação, durante o tempo de vida total do produto (VEHLOW et al., 2000).

As pesquisas existentes, no entanto, têm a maior parte do foco, nos efeitos negativos de metais pesados, tais como $\mathrm{Cd}, \mathrm{Cu}, \mathrm{Pb}$ e Sb, maior destaque é dado aos metais $\mathrm{Cu}$ e $\mathrm{Pb}$, que são frequentemente encontrados como metais puros, entre os resíduos eletrônicos de placas de circuito impresso (VEHLOW et al., 2000).

\subsubsection{Gestão do resíduo eletrônico}

Conforme identificou o relatório do PNUMA de 20 de julho 2009, em relação a gestão dos resíduos eletroeletrônicos WEEE, há dois cenários. Por um lado, existem projetos com tecnologias de reciclagem sustentáveis, que muitas vezes são resultados de iniciativas individuais ou corporativas combinadas com fontes de financiamento do desenvolvimento nacional ou internacional, ou programas de responsabilidade social corporativa. Por outro lado, há uma série de operações ineficientes e insustentáveis, que carecem de normas de segurança direcionadas para a saúde e ao ambiente e falta de aplicação das melhores práticas. Essas operações muitas vezes foram iniciadas por empresários inovadores, mas não evoluiu para os padrões atuais, devido à falta de acesso a recursos financeiros e a tecnologias de reciclagem, bem como a ausência de legislação e aplicação adequada, supõe-se que essas operações possam ser adaptadas a tecnologias inovadoras, somente após receber apoio através de um programa de transferência de tecnologia e melhoria substancial de seus processos para que estas operações tornem-se sustentáveis (UNEP, 2009).

Várias organizações, que compuseram a Convenção da Basiléia, deram o passo inicial ao tentar desenvolver padrões globais desses sistemas de gestão. 
Um objetivo central da Convenção de Basiléia é uma gestão ecologicamente correta, ao redigir medidas práticas para minimizar a geração de resíduos perigosos e um controle restrito de seu armazenamento, transporte, tratamento, reutilização, reciclagem, valorização e os métodos de eliminação, com o propósito de proteger a saúde humana e o meio ambiente.

Os requisitos principais e necessários para realizar a reciclagem de resíduo eletrônico e torná-lo sustentável são melhorar a infra-estrutura, os sistemas de coleta e separação e desenvolver tecnologias para o tratamento dos resíduos (UNEP, 2009).

\subsubsection{Gerenciamento do resíduo eletrônico}

A geração de resíduos e a sua disposição inadequada são agravantes em relação a aspectos ambientais, implantar sistemas que ajudem no gerenciamento destes resíduos, com o objetivo de obter e manter o controle torna-se, fundamental para evitar ou minimizar os impactos na interação com o meio ambiente.

Conforme Zumbuehl (2006, p.12), a Suíça, é uma referência no gerenciamento do resíduo eletrônico. O país estabeleceu em escala nacional, nos anos 90, a adoção dos níveis mais avançados de tecnologias de reciclagem e também adotou medidas com base na iniciativa da indústria eletrônica local. Foi estabelecido um sistema de devolução, financiado por uma taxa de reciclagem.

Atualmente essas ações de gerenciamento são atribuídas a Swiss Association for Information, Commuication and Organisation Technology, SWICO que compreende mais de 400 fornecedores no segmento de TIC e se tornou uma das mais importantes associações do setor na Suíça. Mesmo que um país ou região organize seu sistema de gestão de resíduos eletrônicos dentro da indústria, as legislações têm que ser configuradas para definir o quadro geral. 
Do ponto de vista econômico, as peças valiosas dos resíduos eletroeletrônicos, ou seja, metais preciosos são de interesse particular. Então, essas partes são recuperadas e direcionadas pela demanda do mercado. Para evitar que os recicladores tenham interesse apenas nas partes ("Picking-cereja") e desprezem as peças sem valor de mercado. Portanto, legislações e regulamentações precisam ser adotadas tendo como objetivo principal orientar a descontaminação do resíduo eletrônico (ZUMBUEHL, 2006).

\subsection{Métodos de tratamento de placas de circuito impresso}

\subsubsection{Processo mecânico}

Conforme Moraes (2011, p.17), o processo mecânico envolve essencialmente operações unitárias de tratamento de minérios visando, a separação de materiais a partir de equipamentos eletroeletrônicos inservíveis. Esta etapa do processamento envolve a desmanufatura, a trituração (moagem), classificação granulométrica, separação magnética, separação eletrostática, separação em meio denso.

\subsubsection{Desmanufatura}

As empresas de reciclagem adotam a nomenclatura "placas de circuito impresso descaracterizadas", o que significa a remoção de alguns componentes eletrônicos, das placas desmontadas dos componentes eletrônicos antes de serem encaminhadas ao processo de trituração, comumente utilizado para permitir melhor gestão dos resíduos, para transporte ou armazenamento, do resíduo eletrônico.

\subsubsection{Trituração (moagem)}

O processo de moagem é um método de cominuição ou redução de tamanho para promover a liberação de materiais presentes, neste caso, caracterizado como resíduo, por meio de ação mecânica, o mecanismo de fratura dos materiais é diferente em cada tipo de moinho, que influi no processo de liberação dos materiais, embora os resíduos das placas de circuito impresso sejam basicamente compostos de: fibra de vidro, polímeros e metais (MORAES, 2011). 


\subsubsection{Classificação granulométrica}

A separação granulométrica é a técnica utilizada para separar populações de partículas com tamanhos diferentes, mediante a passagem desta população por uma ou mais séries de gabaritos com aberturas finas e pré-determinadas, conhecidas como peneiras, que são os equipamentos que promovem o peneiramento de materiais após a cominuição (MORAES, 2011).

Para os resíduos eletroeletrônicos a classificação granulométrica foi realizada em peneiras vibratórias horizontais por permitir a separação por tamanho de partícula e facilitar a etapa de caracterização dos materiais por meio de análises químicas possibilitando a identificação das frações de materiais metálicos e não metálicos.

\subsubsection{Separação magnética}

A separação magnética é um método de concentração para o beneficiamento de minérios e remoção de materiais caracterizados como resíduos, no qual a fração magnética é separada, por meio de equipamentos de baixa e alta intensidade. Sendo que os materiais podem ser classificados em três categorias, segundo suas respostas ao campo magnético, os materiais são atraídos ou repelidos pelo campo magnético, tais como: ferromagnéticos, são os materiais, que são atraídos fortemente pelo campo magnético, os paramagnéticos que são atraídos fracamente pelo campo magnético e os diamagnéticos que são repelidos pelo campo magnético (MORAES, 2011).

\subsubsection{Separação eletrostática}

A separação eletrostática é um processo de concentração de minérios e materiais que considera algumas propriedades como a condutividade elétrica; susceptibilidade em adquirir cargas elétricas superficiais; forma geométrica e densidade (MORAES, 2011). 
Existem dois fatores que influenciam na separação eletrostática: a intensidade do campo elétrico para ter a capacidade de desviar uma partícula eletricamente carregada e a carga elétrica superficial das partículas (MORAES, 2011).

Assim o resíduo ou o minério de ferro é separado em material condutor e material não condutor, contudo ainda pode ser obtida uma fração mista, na qual parte do resíduo condutor e não condutor ficam juntos devido a algum tipo de deficiência na liberação do material (MORAES, 2011).

\subsubsection{Processo químico}

Essa técnica é usada para separar partículas sólidas por meio da diferença de densidade. As partículas que tem de ser separadas são imersas em um líquido que tem um valor de densidade intermediária entre os valores dos dois componentes que se pretende separar (ANDRADE, 2002).

\subsubsection{Separação em meio denso}

É um método que permite a separação dos materiais presentes no resíduo eletroeletrônico, o processo envolve o uso de líquidos de alta densidade, foi utilizado como agente as soluções de Clorofórmio e Bromofórmio, o princípio é identificar na fração de material de resíduo eletroeletrônico, em material sobrenadante (fração leve) as partículas mais leves flutuam e o material decantado (fração pesada) as partículas mais pesadas vão para o fundo.

\subsection{Cenários mundiais do resíduo eletrônico}

Por causa do acelerado progresso tecnológico dos sistemas de informação a vida útil dos dispositivos eletrônicos tem diminuído. O resíduo eletrônico está crescendo rapidamente, dando origem a um novo problema sócio ambiental. No ano de 2004, mais de 180 milhões de computadores pessoais foram vendidos no mundo. Nesse mesmo ano, cerca de 100 milhões de PCs tornaram-se obsoletos entrando no fluxo de resíduos (WIDMER et al., 2005). 
Conforme, Zumbuehl (2006) o crescimento do resíduo eletrônico em todo o mundo pode ser estimado e está na faixa aproximada de 20 a 50 milhões de toneladas por ano. A gestão e o controle dos volumes crescentes dos componentes eletrônicos que se tornam obsoletos passam a ser de grande importância. O volume principal é produzido na América do Norte, seguido da Europa e Ásia, enfatizando que esta é uma das frações de resíduos de crescimento mais rápido, responsável por cerca de $8 \%$ de todo o lixo da Europa. Atualmente, o resíduo eletrônico é gerado principalmente pelos países industrializados, que já têm uma alta quantidade de equipamentos elétricos e eletrônicos. Supõe-se que alguns dos resíduos eletrônicos, que são gerados por países industrializados, acabam nos países em desenvolvimento como Índia ou África.

A Agência de Proteção Britânica divulgou um relatório admitindo que uma grande quantidade de resíduo eletrônico, foi exportada ilegalmente do Reino Unido (AGARWAL, 2005). Conforme Zumbuehl (2006), em Lagos, na Nigéria, 400.000 computadores usados chegam a entrar no país por mês, sendo que de $25 \%$ a $75 \%$ deles não funcionam e têm que ser eliminados. Os EUA exportaram 10,2 milhões de computadores obsoletos (ou cerca de $50-80 \%$ de todos os PCs enviados para reciclagem são originados nos EUA) tendo como destino a Ásia, em 2002. As razões para essas exportações poderiam ser os padrões ambientais menos rígidos nos países em desenvolvimento e a redução dos custos de descarte. Por exemplo, descartar um computador nos EUA pode custar até vinte dolares, enquanto um comerciante indiano, paga entre 10 e 15 Rupias Indiana por um computador em desuso. No futuro, no entanto, uma grande quantidade de resíduos eletroeletrônicos será produzida pelos países em desenvolvimento (Zumbuehl, 2006).

Devido ao desenvolvimento, países como Brasil, Índia, China e África, enfrentarão uma crescente quantidade de resíduo eletrônico. Para lidar com o de crescimento rápido, valioso e carregado de resíduos perigosos, esse fluxo de resíduos tem de ser gerido de forma adequada e tem que ser controlado, colocandose diretrizes e regulamentos. (Zumbuehl, 2006). 


\subsubsection{Cenário europeu}

Embora alguns fabricantes estejam introduzindo produtos que facilitem a desmontagem e a reciclagem dos materiais, muitos dos produtos que estão disponíveis para reciclagem, atualmente, foram projetados há 15 ou 20 anos atrás, quando os materiais empregados para a manufatura, não eram consideradas as suas futuras reutilizações (RON et al., 1995).

Famílias alemãs por volta de 1990, já produziam uma quantidade de resíduo eletroeletrônico bruto de aproximadamente de 800.000 toneladas. Para o ano de 1992 estima-se que tenham, sido descartadas 3.000 toneladas de computadores (RON et al., 1995).

A Comunidade Européia adotou em 2003 a diretiva 2002/96/CE WEEE (Resíduos de Equipamentos Elétricos e Eletrônicos) instituída pelo Parlamento Europeu e pelo Conselho da União Européia. Este regulamento está atualmente em vigor e orienta os estados membros da EU, quanto aos principais objetivos e regulamentos. Estes são: a prevenção do WEEE, reutilização, reciclagem e outras formas de valorização, tendo como objetivo também, a redução e a eliminação dos WEEE como resíduos urbanos diferenciados. Atualmente, a maior parte dos custos é gerada nas fases, de eliminação e reciclagem de resíduos eletroeletrônicos, são devido às suas substâncias perigosas (ZUMBUEHL, 2006).

A Diretiva RoHS (Restriction ontheuse of Hazardous Substances) refere-se às restrições de substâncias perigosas e tem como objetivo reduzir o teor de substancias perigosas. Instituída pelo Parlamento Europeu e pelo Conselho da União Européia, proíbe várias substâncias perigosas na fabricação de equipamentos eletroeletrônicos. Materiais como mercúrio, chumbo ou Bifenil Polibromados (PBB) que são utilizados como retardadores de chamas em vários tipos de plásticos, necessitam ser substituídos por outros materiais que ofereçam alternativas mais seguras tecnologicamente e economicamente viáveis (ZUMBUEHL, 2006). 


\subsubsection{Cenário africano}

Como recicladores formais, a Empresa de Reciclagem Universal da África do Sul, processa aproximadamente 1800 toneladas de sucata eletrônica por ano, usando tecnologia sofisticada, linhas de "desmontagem", incluindo trituradores, mecânicos, pulverizadores, ímãs rotativos, granuladores, tesouras e enfardadeiras. Os materiais ferrosos são separados dos materiais não-ferrosos, tal como alumínio, utilizando uma centrifuga como separador. Os metais pesados e preciosos são enviados para uma refinaria européia. $O$ aço é processado localmente e alumínio é exportado para o Extremo Oriente. Frações de material não metálico, são depositados em aterros. Quanto ao plástico não existe um mercado estruturado para este material.

A empresa Desco Electronic Recyclers, está em conformidade com os requisitos de reciclagem ambientais rigorosas e melhores práticas, é uma empresa certificada e auditada por uma empresa internacional para os padrões do Sistema de Gestão Ambiental ISO 14001, especializada na reciclagem de resíduos eletroeletrônicos, denomina-se a maior recicladora da África do Sul de placas de Circuito Impresso (PC boards). As placas são compradas de sucateiros e indústrias de toda a África do Sul e de países vizinhos. Processam aproximadamente 400 toneladas por ano de placas de placas de circuito impresso e 2000 toneladas por ano de sucata eletrônica em geral, incluindo equipamentos de telecomunicações, equipamentos médicos, computadores desktops e mainframes. Toda a sucata eletrônica é desmontada manualmente, em um processo trabalhoso que gera empregos para a população local. As placas de circuito impresso são processadas, com maquinário especializado projetado e construído pela própria empresa. Nesse processo de reciclagem não são utilizados produtos químicos ou incineração deste tipo de material (WIDMER et al., 2005).

Levantamentos preliminares sugerem uma situação informal nos processo de reciclagem dos resíduos eletroeletrônicos, sendo que em relação aos metais preciosos, esses são estritamente regulamentados, na África do Sul, características de status substancialmente do diferente do encontrado na Índia e na China. 
Atualmente, na África do Sul, operam cinco aterros, depósitos de resíduos sólidos, estima-se que sejam depositados nos aterros de Weltervreden Park no município metropolitano Johannesburg e em Brakpan no município metropolitano Ekurhuleni, a média mensal, 2.200 toneladas de resíduos eletroeletrônicos (WIDMER et al., 2005).

$\mathrm{Na}$ África do Sul a disposição final da maioria dos resíduos eletroeletrônicos e a eliminação dos resíduos perigosos são autorizadas em locais de aterros como o de Holfontein no município metropolitano Merafong, por intermédio do pagamento de uma taxa, é fornecida uma autorização para o descarte, com isso, o cliente recebe um certificado de eliminação segura. Esse material pode também ser descartado no fluxo de resíduos urbanos ou depositado em aterros no local de eliminação de resíduos geral. A recuperação informal é desencorajada de acordo com diretivas do governo. Muito pouco dos resíduos eletroeletrônicos são recuperados a partir de aterros autorizados na África do Sul (WIDMER et al., 2005).

Em relação à geração dos resíduos eletroeletrônicos, geralmente, o ciclo de vida dos PCs é estimada em 7 anos. Os primeiros 3 anos, com 0 primeiro proprietário, 2 anos com o segundo proprietário e mais dois anos com um terceiro proprietário ou são armazenados (ZUMBUEHL, 2006).

De acordo com Widmer et al. (2005), a relação entre a taxa de entrada do PCs para o mercado de $\mathrm{Tl}$ e a expectativa de geração de resíduos eletroeletrônicos após 7 anos do ciclo de vida, período no qual o equipamento torna-se obsoleto. Nos diferentes países, revela-se o enorme crescimento, per capita de PCs. No entanto na África do Sul, o fluxo de resíduos não reflete esta situação, sendo que as máquinas mais obsoletas ainda são armazenadas.

\subsubsection{Cenário americano}

Nos Estados Unidos o resíduo eletrônico representa um segmento crescente do fluxo de resíduos sólidos. De acordo com um estudo preparado pela Agência de Proteção Ambiental americana (EPA), estima-se que o volume de dispositivos eletrônicos descartados seja de aproximadamente $2 \%$ a $5 \%$ do fluxo de resíduos 
sólidos urbanos (RSU) municipais. Uma projeção feita por especialistas da indústria, traçaram um cenário, que mais de 20 milhões de computadores estariam obsoletos em 1998 e mais de 60 milhões de computadores seriam reformados em 2005 e cerca de 3 milhões de toneladas de resíduos eletrônicos estariam em depósitos de resíduos (TOWNSEND et al., 2003).

Nos Estados Unidos, estima-se que em 2006 foram colocados no mercado mais de 34 milhões de TVs, mais de 24 milhões de PCs e cerca de 139 milhões de dispositivos portáteis de comunicação, como telefones celulares, pagers ou smartphones. Com esses dados, há que se destacar o maior crescimento dos equipamentos de comunicação (UNEP, 2009).

Segundo a organização não-governamental Greenpeace em conjunto com a Basel Action Network Organization de Seattle, constatou-se que 90\% dos resíduos eletrônicos americano são transportados para outros países, sendo que $37 \%$ são destinados para a China (EUGSTER, 2004).

Em 2001, apenas 11\% dos computadores pessoais obsoletos nos EUA foram reciclados. No entanto, as plantas de reciclagem modernas podem recuperar $80 \%$ dos materiais e utilizar os outros $15 \%$ para a reutilização, mas apenas 5\% acabam sendo transformados em rejeitos (EUGSTER, 2004).

Em um levantamento efetuado pela Basel Action Network (BAN) organização mundial que trabalha na prevenção da toxicidade, identificou-se que uma das razões da exportação do resíduo eletrônico pelos Estados Unidos é o fato da mesma não ser signatária de uma regulamentação internacional, que proíbe a exportação de resíduo eletrônico. Assim, pode sempre optar por despejar resíduo eletrônico em outros lugares, a um custo mínimo, sendo Hong Kong um dos destinos do resíduo eletrônico. Parte desse material vai para outros destinos como Índia, Paquistão e Nigéria. Para os EUA, o custo de enviar o resíduo eletrônico para o exterior é menor do que jogá-lo em aterros sanitários.

Antes de ocorrer a separação, os resíduos são enviados e transferidos a compradores, vendedores e corretores, tornando difícil o rastreamento. 
Em última análise, chegam às cidades pobres na China, Paquistão e Índia, onde o custo da mão de obra é menor (FINLAY, 2005).

Empresas de porte adotaram acordo com a Agência de Proteção Ambiental americana (Environmental Protection Agency, EPA, 2007), baseando-se na condição de que os produtores podem e devem assumir a responsabilidade pelo traço deixado por seus produtos no meio ambiente. É uma ação em conjunto com os distribuidores, comerciantes e consumidores considerando a infra-estrutura atual para a gestão de resíduos para envolver e se comprometer a desenvolver a solução mais eficaz para a gestão de resíduos em termos ambientais e econômicos. Há exemplos de empresas, como a Epson, que estabeleceram a destruição e eliminação das partes obsoletas das suas impressoras em aterros autorizados a receber resíduos perigosos. A HP introduziu um programa de reciclagem para cartuchos de impressora laser e terceirizou o recolhimento e o envio para sua fábrica na Virginia (EUA) para efetuar a reciclagem. A IBM possui um sistema de logística reversa para recolher as peças de suas diferentes equipes e centros de assistência técnica e de acordo com a condição do dispositivo, tomam a decisão de reparar ou descartar (ESPINOZA et al., 2008).

\subsubsection{Cenário chinês}

Na China, em 2004, os números dos eletroeletrônicos descartados foram de: 15.000 toneladas de aparelhos eletrodomésticos, 5.000 toneladas de computadores e 10.000 toneladas de aparelhos celulares. A produção de placas eletrônicas cresce $8,7 \%$ ao ano e em 2003 a China se tornou o segundo maior produtor do mundo. $\mathrm{Na}$ cidade de Guiyu na China, devido à recuperação de metais de forma inapropriada, incluindo queima a céu aberto, foram encontradas elevadas concentrações e contaminações no solo de substâncias tais como: éteres difenílicos polibromados sendo esta uma das inúmeras substancias carcinogênicas e foi também identificada uma alta concentração de metais pesados como cádmio, chumbo, cobre e zinco em amostras de sedimentos de um rio (ANDRADE, 2010).

Situações de manuseio inadequado de resíduo eletrônico na China, Índia e nos países africanos são agravadas por causa da informalidade com que são tratados os materiais a serem recuperados (ESPINOZA et al., 2008). 
Segundo SCHLUEPA, desde 2004 a China passou a ter interesse em receber um grande volume de WEEE para reciclagem, seja no mercado informal ou formal, pois ambos os recursos disponibilizam uma seleção de oportunidades atraentes para transferência de tecnologia. Houve vários projetos nacionais e internacionais de projeto-piloto sobre resíduos, realizados na China. Entre eles, o projeto-piloto de cooperação com os suíços, o primeiro grande sistema da China dedicado a iniciar em instalações adequadas a reciclagem de resíduo eletrônico em quatro cidadesalvo em toda a China desde 2004, exploram a reciclagem eco-eficiente, que é uma filosofia de gestão que encoraja o meio empresarial a procurar melhorias ambientais que potencializem uma abordagem adaptada à situação local chinesa (UNEP, 2009).

Equipamentos eletrônicos de marcas famosas em geral foram encontrados desmontados e armazenados em larga escala em ferros-velhos de Guiyu e Taizhou, na China.

A maioria das exportações para a China de resíduo eletrônico envolve componentes altamente tóxicos, em quantidades significativamente altas de poluentes de resíduos eletrônicos, como carregadores de telefone celular, laptops, computadores e impressoras. Grande parte deste resíduo eletrônico está entrando na China ilegalmente proveniente de países como Japão e Coréia do Sul (FINLAY, 2005).

O processo legislativo sobre a gestão do resíduo eletrônico é lento. Falta uma regulação especifica e detalhada sobre a definição dos produtores e as responsabilidades dos consumidores, coleta e reciclagem de destino e plano de subsídio financeiro. Houve tentativas de introduzir uma política padrão para tratar o resíduo eletrônico, mas devido à situação social e econômica diferente entre as várias regiões e províncias na China, não há uma especificação clara das responsabilidades governamentais e não há uma coordenação ou plataforma global para o trabalho conjunto, devido à hierarquia e burocracia dos chineses. O sistema de legislação é regional conforme interpretação da autoridade provincial da cidade. Introduzir uma política geral ditada pelo governo central poderia ser de uma grande complexidade e confusão para todo a sistema nacional (UNEP, 2009). 


\subsubsection{Cenário japonês}

No Japão, em 1999, foram descartadas 40.000 toneladas de computadores pessoais, no ano de 2000 foram descartadas 50.000 toneladas e no ano de 2002, 80.000 toneladas, demonstrando o aumento significativo deste tipo de resíduo (ANDRADE, 2010).

O sistema japonês, de reciclagem dos WEEE é uma responsabilidade específica do produtor. O Poder Público impôs obrigações de retorno aos fabricantes, que incorporaram a preocupação ambiental à sua estratégia de negócios. O descarte de equipamentos eletroeletrônicos é uma responsabilidade estendida do produtor e partilhada entre o produtor e os consumidores que pagam uma taxa quando trazem seus equipamentos usados para serem depositados nos coletores. A lei também especifica metas de taxa de reciclagem e impõe penalidades pesadas pelo descumprimento. Em 2004, havia 41 indústrias de reciclagem para resíduos eletrônicos no Japão. A maioria delas tem suporte financeiro do Poder Público ou dos produtores de equipamentos elétricos e eletrônicos. O resíduo eletrônico é recolhido em lojas de varejo quando estão descarregados ou quando os consumidores compram novos produtos. A coleta do resíduo eletrônico é transferida às coletoras e finalmente transferida às fábricas, pelo sistema de distribuição. $O$ Japão apresenta um sistema organizado que demonstra que é possível compatibilizar rentabilidade econômica com segurança e cuidados para com o meio ambiente (NNOROM, 2008).

\subsubsection{Cenário brasileiro}

Conforme a ASSOCIAÇÃO BRASILEIRA DAS EMPRESAS DE LIMPEZA PÚBLICA E RESÍDUOS ESPECIAIS - (ABRELPE) (2010), o passivo eletroeletrônico no Brasil, em 2005, era composto por 480.000 toneladas de computadores e 0 panorama projetado para o Brasil, no intervalo de 2001 a 2030, estimou a produção média de 680.000 toneladas/ano de resíduos eletrônicos. 
Estima-se que a geração per capita de WEEE no período de 2001 a 2030 seja igual a 3,4 kg/hab/ano; e a projeção de acúmulo de WEEE no mesmo período seja igual a 22 milhões de toneladas.

Conforme o relatório do Programa das Nações Unidas para o Meio Ambiente, (PNUMA), que identificou e classificou as potencialidades para a introdução de processos e tecnologias de reciclagem, conforme as características apresentadas por cada um dos 11 países, envolvidos no estudo, foi possível formar 3 grupos.

Grupo A, composto por (Quênia, Uganda, Senegal e Peru) são classificados como promissores para a introdução de pré-processamento e tecnologias inovadoras com um forte apoio na capacitação.

Grupo B, composto por (Índia e China) são classificados como tendo um potencial significativo para a introdução de pré-processamento e de tecnologias fins com um forte apoio na construção de capacidades no sector informal.

Grupo C, composto por (África do Sul, Marrocos, Colômbia, México e Brasil) são classificados como tendo, até certo ponto, um potencial significativo de préadaptação de um processamento final de tecnologia para suas próprias necessidades, em consequência de um repasse de conhecimentos e de tecnologia (UNEP, 2009, p.58).

As informações sobre a situação dos resíduos eletrônicos no Brasil é escassa e não abrangente. Um estudo de avaliação preliminar efetuado em conjunto pelo programa das nações unidas para o meio ambiente (PNUMA) e pelo instituto pesquisa suíço de ciência dos materiais (EMPA), em outubro de 2008, foi publicado em julho de 2009, apontou os seguintes problemas:

Apontou a falta de uma política e de uma legislação no âmbito federal, provocando uma falta de gestão o que pode ser visto, como um grande obstáculo para o desenvolvimento de uma regulamentação de resíduo eletrônico. 
A reciclagem de resíduo eletrônico no Brasil existe por todo o país, mas é especializada em partes específicas dos materiais, que têm um elevado valor agregado (tais como placas de circuito impresso, aço inoxidável, cobre, etc....).

Portanto, a reciclagem do resíduo eletrônico atualmente é feita, apenas, em partes que representam algum valor e não de uma forma sustentável.

O resíduo eletrônico não parece ser uma alta prioridade para o governo federal, para a maioria dos representantes da associação da indústria de produção e montagem e para os representantes de tecnologia de informação e comunicação.

Um sistema de coleta e reciclagem de resíduo eletrônico, com a cobrança de taxa extra, parece ser muito impopular, sendo que o sistema tributário brasileiro já coloca encargos elevados para os produtores e consumidores (UNEP, 2009).

A figura 2.1 baseada em levantamento do PNUMA, ilustra entre alguns dos diferentes países da América Latina, separados por faixas de quantidades em toneladas a composição de resíduos eletroeletrônicos no período de 2005 a 2006 (ABRELPE, 2010).

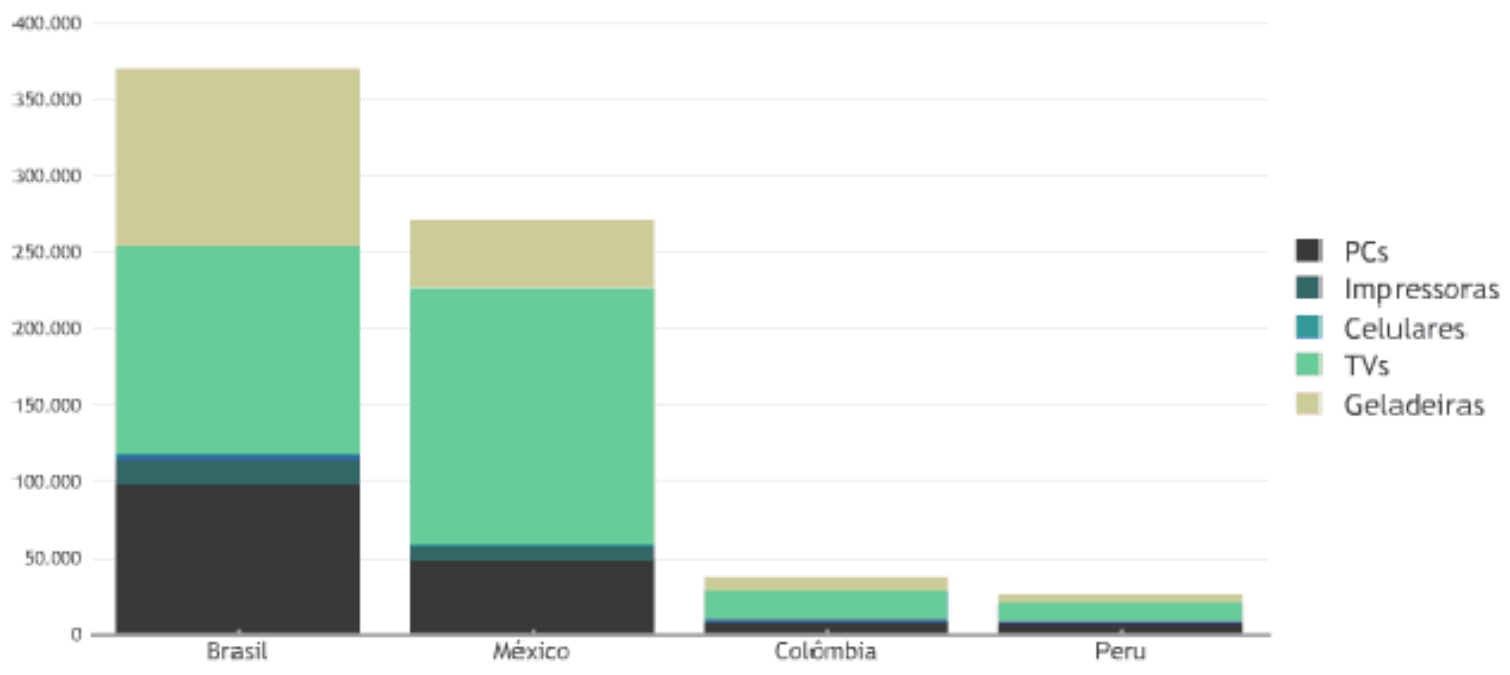

Figura 2.1 - Resíduo eletrônico entre alguns países emergentes da America Latina. 


\subsection{MARCOS REGULATÓRIOS}

\subsubsection{Europa}

Em 2003, a Comunidade Européia por meio do Parlamento Europeu e do Conselho da União Européia, adotou a Diretiva 2002/96/CE.

Este regulamento atualmente em vigor tem como objetivo principal orientar os estados membros da comunidade européia, em relação à prevenção do WEEE (Resíduos de Equipamentos Elétricos e Eletrônicos), em sua reutilização, reciclagem e outras formas de valorização e também em relação a redução e eliminação do WEEE como resíduo urbano, sendo que as substâncias perigosas encontradas na composição desses produtos, elevam o custo dos processos de eliminação e a reciclagem de resíduos eletrônicos.

Foi também adotada pela Comunidade Européia por meio do Parlamento Europeu e do Conselho da União Européia, em 2003, a Diretiva de Restrições de Substâncias Perigosas (RoHS), que tem como objetivo definir a redução e a proibição de várias substâncias perigosas utilizadas na fabricação de equipamentos eletro eletrônicos.

Materiais como bifenilos, mercúrio, chumbo ou polibromados (PBB), devem ser substituídos por outros alternativos mais seguros, viáveis tecnologica e economicamente.

O apêndice da diretiva RoHS especifica algumas exceções, tal como para o uso de mercúrio em lâmpadas fluorescentes ou a solda de cádmio utilizada em tubos de raios catódicos e cromo hexavalente e dispositivos que contêm chumbo (ZUMBUEHL, 2006).

\subsubsection{Diretivas WEEE e ROHS}

Como o crescimento da quantidade de resíduos eletroeletrônicos tem chamado a atenção das agências governamentais e fabricantes, as políticas da 
União Européia em relação aos resíduos de equipamentos elétricos e eletrônicos abrangem uma ampla relação de produtos, incluindo aparelhos eletrodomésticos, equipamento de $\mathrm{TI}$ e telecomunicações, equipamento de iluminação e bens de consumo como rádios, televisores e câmaras de vídeo.

Tais produtos comportam muitos e variados materiais e componentes, alguns dos quais caracterizados como perigosos. Faz-se desta e peculiar razão pela qual os resíduos de equipamentos elétricos e eletrônicos, se não forem adequadamente tratados, podem causar graves problemas ambientais.

Os equipamentos elétricos e eletrônicos são constituídos de numa combinação de diversos módulos básicos, tais como placas de circuitos, cabos e fios, plásticos contendo retardadores de chama, disjuntores de mercúrio, equipamento de visualização (como tubos de raios catódicos e cristais líquidos), acumuladores, pilhas e baterias, dispositivos luminosos, etc.

Alguns desses componentes contêm substâncias ambientalmente problemáticas. Incluem-se certos metais pesados (mercúrio, chumbo, cádmio e cromo) e substâncias halogenadas (Clorofluorcarboneto, Bifenilas Policloradas, Poli Cloreto de Vinila e retardadores de chama bromados). Muitas dessas substâncias podem ser tóxicas, induzindo riscos para a saúde humana. Em relação aos resíduos desses tipos de equipamentos a União Européia, adotou duas diretivas.

A diretiva relativa aos resíduos de equipamentos elétricos e eletrônicos (Diretiva REEE), também denominada diretiva WEEE (Waste from Electrical and Electronic Equipment), que visa prevenir a produção, define algumas restrições no uso de determinadas substâncias consideradas perigosas em novos equipamentos eletroeletrônicos e em processos de produção. Da mesma forma, determina as concentrações permitidas dessas substâncias em determinados equipamentos e promove a reutilização, a reciclagem e outras formas de aproveitamento e valorização esses resíduos, a fim de reduzir ou até mesmo eliminar a quantidade de resíduos (DIRECTIVA 2002/96/CE, 2003). 
A diretiva relativa à restrição do uso de determinadas substâncias perigosas em equipamentos elétricos e eletrônicos (Diretiva RSP), também denominada diretiva RoHS (Restriction of Hazardous Substances), tem como objetivo propor, quando existam, alternativas, a substituição do chumbo, do mercúrio, do cádmio, do cromo hexavalente, dos bifenílas polibromadas (PBB) nos equipamentos elétricos e eletrônicos (DIRECTIVA 2002/95/CE, 2003).

Tais ações são propostas a fim de facilitar uma valorização correta e a prevenção dos problemas durante a fase de gestão dos resíduos.

\subsubsection{América Latina}

$\mathrm{Na}$ América Latina ainda não há um sistema abrangente de gestão estabelecido e até agora não emitiu qualquer regulamentação específica a este respeito. No entanto, o problema foi reconhecido e há várias iniciativas em diferentes países. Argentina, Chile, Costa Rica, Peru e Brasil, que têm realizado estudos para detectar a situação atual, precisam de ação urgente.

A Costa Rica estava em processo de elaboração de uma legislação específica sobre resíduo eletrônico. Formou também um grupo de trabalho para definir a base para a introdução de um sistema baseado em uma taxa prevista de reciclagem.

O Chile tem declarado repetidamente sua intenção de resolver o problema do resíduo eletrônico, enquanto que ao mesmo tempo promove iniciativas do setor privado à espera de uma regulamentação obrigatória (OTT, 2008).

Iniciativa de corporações como SUR Corporação de estudos sociais e educação de Santiago do Chile com o apoio do International Development Research Centre (IDRC) do Canadá, moldaram uma plataforma para a pesquisa aplicada sobre a reciclagem de computadores (OTT, 2008).

Algumas empresas de reciclagem conhecidas como Recycla, Degraf Ltda, atuam na reciclagem de equipamentos elétricos e eletrônicos e resíduos perigosos que exigem tratamento especial (OTT, 2008). 
Na Argentina há também um negócio de sucesso, a reciclagem de resíduos eletrônicos, que trabalha em estreita colaboração com a Silkers SA, uma empresa que recupera metais.

O Peru formou um comitê de resíduo eletrônico com os representantes dos setores público e privado, impulsionado pelo IPES (OTT, 2008).

Os países da América Latina e do Caribe que assinaram o tratado são: Antígua e Barbuda, Argentina, Bahamas, Barbados, Belize, Bolívia, Brasil, Chile, Costa Rica, Cuba, República Dominicana, Equador, Colômbia, El Salvador, Guatemala, Honduras, México, Nicarágua, Panamá, Paraguai, Peru, Saint Kitts e Nevis, Santa Lúcia, São Vicente e Granadinas, Trinidad e Tobago, Uruguai e Venezuela.

\subsubsection{Brasil}

A Constituição Federal Brasileira, promulgada em 1988, trata de forma abrangente os assuntos relacionados à preservação do meio-ambiente e ao desenvolvimento sustentável da economia, reservando à União, aos Estados, ao Distrito Federal e aos Municípios, a tarefa de proteger o meio ambiente e de controlar a poluição.

No estado de São Paulo a Lei Estadual no. 12.300/2006; de 16 de março de 2006, institui a Política Estadual de Resíduos Sólidos, e define os princípios e diretrizes, objetivos, instrumentos para a gestão integrada e compartilhada de resíduos sólidos, com vistas à prevenção e ao controle da poluição, à proteção e à recuperação da qualidade do meio ambiente, e à promoção da saúde pública, assegurando o uso adequado dos recursos ambientais no Estado.

A Política Estadual de Resíduos Sólidos tem como objetivo o uso sustentável, racional e eficiente dos recursos naturais; a preservação e a melhoria da qualidade do meio ambiente, da saúde pública e a recuperação das áreas degradadas por resíduos sólidos; reduzir a quantidade e a nocividade dos resíduos sólidos, para evitar os problemas ambientais e de saúde pública, por eles gerados e erradicar os "lixões", "aterros controlados", "bota-foras" e demais destinações inadequadas, e fomentar a implantação do sistema de coleta seletiva nos Municípios. 
O Estado de São Paulo possui uma lei específica para tratamento de resíduos tecnológicos (Lei oㅜ 13.576, de 6 de julho de 2009) que institui normas e procedimentos para a reciclagem, gerenciamento e destinação final do resíduo tecnológico, com vistas à prevenção e ao controle da poluição, à proteção e à recuperação da qualidade do meio ambiente. Tem como objetivo dar uma destinação adequada que não provoque danos ou impactos ao meio ambiente e à sociedade, mediante processos de reciclagem e aproveitamento do produto ou componentes para a finalidade original ou diversa, práticas de reutilização total ou parcial de produtos e componentes tecnológicos provendo a neutralização e disposição final apropriada dos componentes tecnológicos equiparados a lixo químico, assegurando o uso adequado dos recursos ambientais no Estado de São Paulo (ALESP, 2009).

Para efeito dessa lei, são considerados o lixo tecnológico os aparelhos eletrodomésticos, equipamentos e componentes eletroeletrônicos de uso doméstico, industrial, comercial e de serviços, que estejam em desuso e sujeitos à disposição final incluindo os componentes e periféricos de computadores. A responsabilidade pela destinação final é solidária entre as empresas que produzam, comercializem ou importem produtos e componentes eletroeletrônicos (MMA, 2010).

No Estado do Paraná, a lei ㄲo 12493 de 1999 definiu princípios e regras rígidas aplicadas à geração, acondicionamento, armazenamento, coleta, transporte, tratamento e destinação final dos resíduos sólidos. Foi determinado como prioridade, reduzir a geração de resíduos sólidos através da adoção de processos mais atualizados tecnologicamente e economicamente viáveis, dando-se prioridade à reutilização ou reciclagem de resíduos sólidos a despeito de outras formas de tratamento e disposição final (ALEP, 1999).

Em alguns casos a legislação ambiental brasileira se faz, por resoluções do Conselho Nacional do Meio Ambiente (CONAMA) que define a destinação final de certos resíduos, a resolução do CONAMA no. 257, trata das baterias e pilhas esgotadas em sua utilização. Determinou aos produtores, a responsabilidade pelo gerenciamento da coleta, classificação e transporte dos produtos descartados, assim como o tratamento prévio dos mesmos. A Agência Nacional de Vigilância Sanitária - 
ANVISA é o órgão governo federal responsável por regulamentar a produção e a comercialização de vários produtos.

Tem sua competência de atuação estabelecida pelo ministro de estado da saúde para determinar a realização de ações previstas em casos específicos e que impliquem em risco à saúde da população, tais como estabelecer, coordenar e monitorar os sistemas de vigilância toxicológica e farmacológica, estabelecer normas, propor, acompanhar e executar as políticas, diretrizes e as ações de vigilância sanitária. Dentre os diversos regulamentos publicados pela ANVISA, destaca-se a Portaria o 2.914, de 14 de dezembro de 2011. Dispõe sobre os procedimentos de controle e de vigilância da qualidade da água para consumo humano e seu padrão de potabilidade. 


\section{MATERIAIS E MÉTODOS}

\subsection{Materiais}

Os materiais utilizados são as placas de circuito impresso, (motherboard), de diversos modelos e fabricantes: AT, ATX, RTX, LPX e ITX.

A primeira etapa do desenvolvimento experimental teve como material de partida $2 \mathrm{~kg}$ de placas de circuito impresso, do tipo placa-mãe, (motherboard).

A Figura 3.1 ilustra o material de partida, placas de circuito impresso, esse material é apresentado no tamanho aproximado da ordem de 1 a $2 \mathrm{~cm}$, já descaracterizado, podendo-se notar os diferentes tamanhos e formas. A nomenclatura "placas de circuito impresso descaracterizadas", significa a remoção de alguns de seus componentes eletrônicos, antes de serem encaminhadas ao processo de trituração.

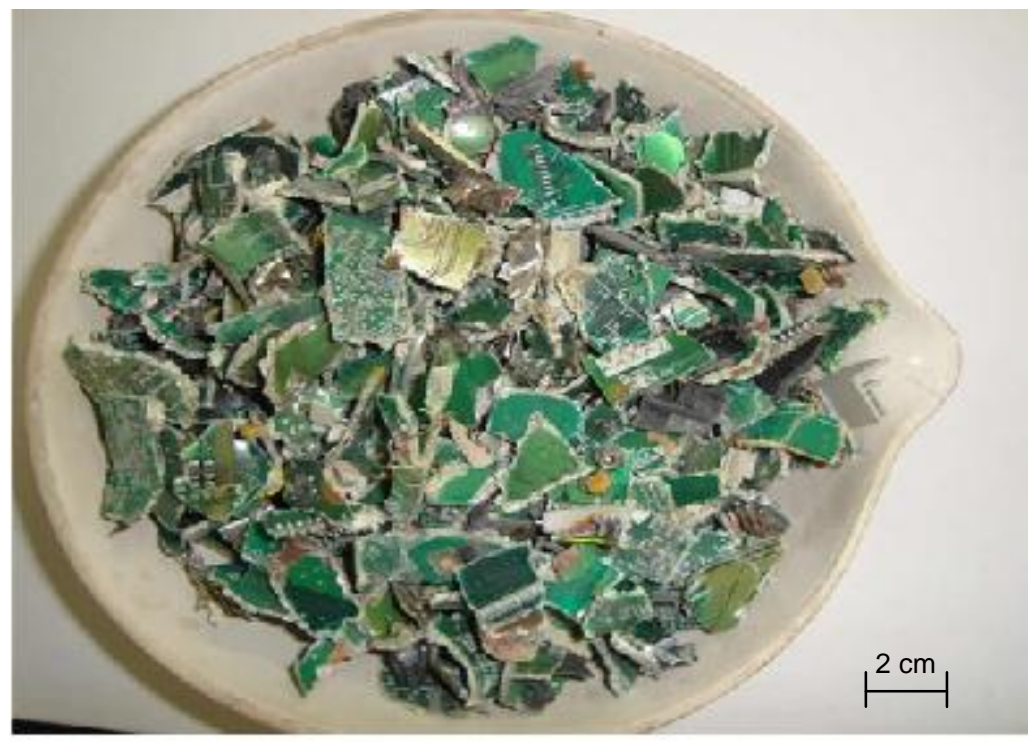

Figura 3.1 - Placas de circuito impresso descaracterizadas.

\subsection{Primeira etapa do procedimento experimental}

Essa etapa envolveu os seguintes processos:

1. A trituração primária (moagem) do material;

2. A separação granulométrica;

3. A separação por densidade em mesa vibratória;

4. A separação física (magnética e eletrostática);

5. A separação gravimétrica; 
Os procedimentos adotados em cada uma das etapas e as caracterizações realizadas são apresentados, na Figura 3.2 por meio do fluxograma do desenvolvimento experimental.

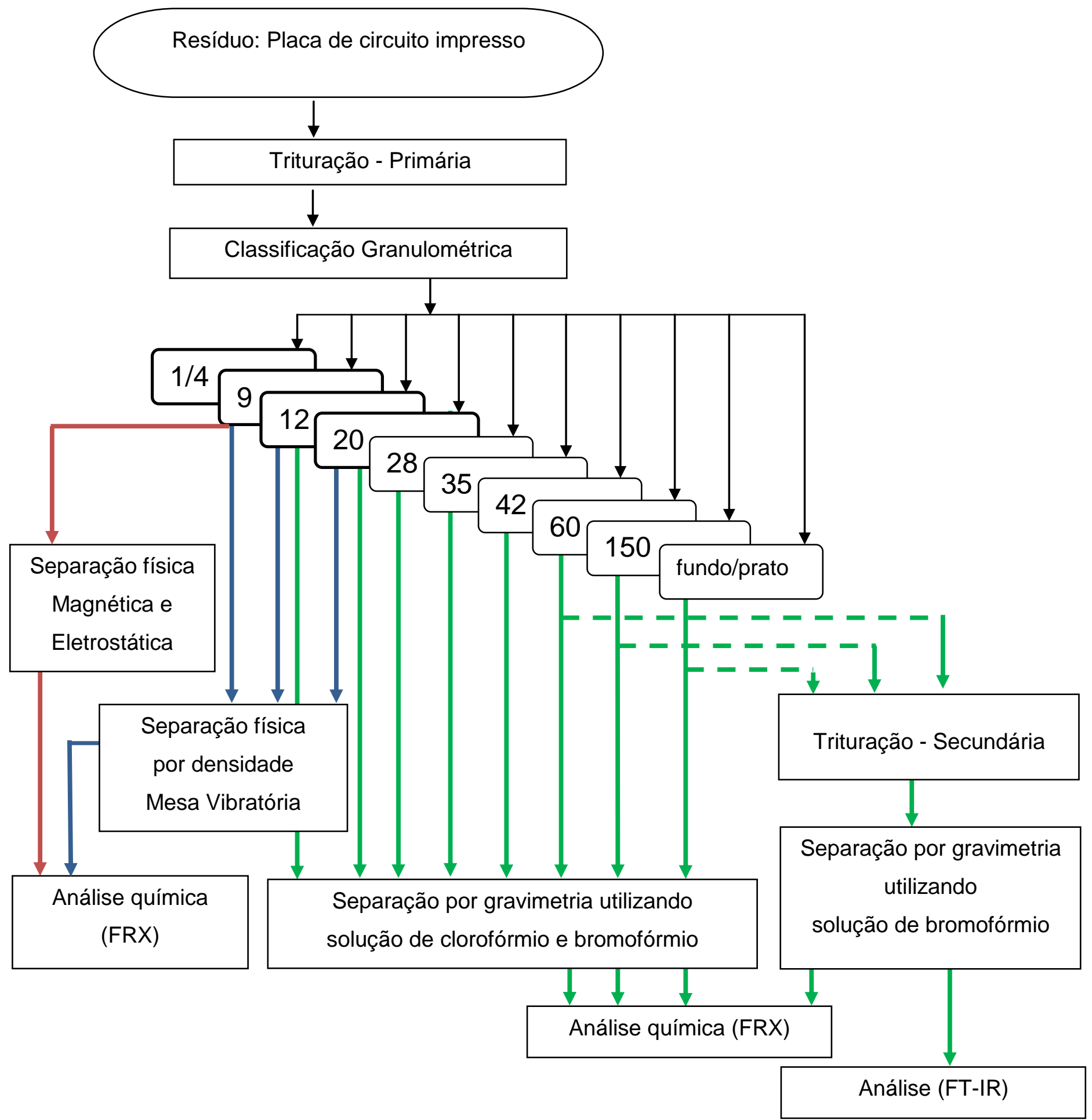

Figura 3.2 - Fluxograma esquemático do procedimento experimental 


\subsubsection{Etapa de Trituração Primária (moagem)}

O processo de trituração utilizou um moinho de martelo da marca Tigre, modelo A-3, comumente utilizado para permitir melhor gestão dos resíduos, para transporte ou armazenamento, a trituração teve como objetivo fragmentar ainda mais o material, por ser bastante aglutinado em seu processo de construção.

\subsubsection{Etapa de Classificação Granulométrica}

A classificação foi feita por meio de um conjunto de peneiras acopladas a uma máquina vibratória, da marca Produtest, com reostato ajustado em 30 minutos, para obter a separação necessária.

O conjunto de separação é composto de peneiras da marca Granutest, cada uma das peneiras são descritas na tabela 3.1 , sendo classificadas da maior abertura de malha para a menor.

Tabela 3.1 - Abertura das malhas das peneiras.

\begin{tabular}{|c|c|c|}
\hline Abertura da malha & Tyler & ASTM E11 - 1995 \\
\hline $\mathbf{m m}$ & Mesh & - \\
\hline 6,30 & - & $1 / 4$ in \\
\hline 2,00 & 9 & № 10 \\
\hline 1,40 & 12 & -------- \\
\hline-------- & -------- & - \\
\hline $\boldsymbol{\mu m}$ & Mesh & № 20 \\
\hline 850 & 20 & № 30 \\
\hline 600 & 28 & № 40 \\
\hline 425 & 35 & № 45 \\
\hline 355 & 42 & № 60 \\
\hline 250 & 60 & - \\
\hline 100 & 150 & № \\
\hline Fundo (prato) & $>150$ & \\
\hline
\end{tabular}

Todas as frações foram pesadas em balança semi-analítica da marca Mettler Toledo e modelo PR1203, sendo posteriormente submetidas a diferentes rotas de separação de metais e não metais. 


\subsubsection{Etapa de separação por densidade em mesa vibratória}

Na separação física por densidade utilizando uma mesa vibratória, da marca OTA IRON WORKS LTD - KUMANOTMIT-NICHI-SOSUI-DORI - SAKYO-KU, KIOTO, JAPAN, modêlo wilfley concentrating table, com dimensões de $1000 \times 450 \mathrm{~cm}$, com motor de 400 watts, com a velocidade de 300 RPM e com inclinação lateral de deslocamento de cerca de 5 graus.

A Figura 3.3, ilustra uma mesa vibratória utilizada para a separação física por densidade.

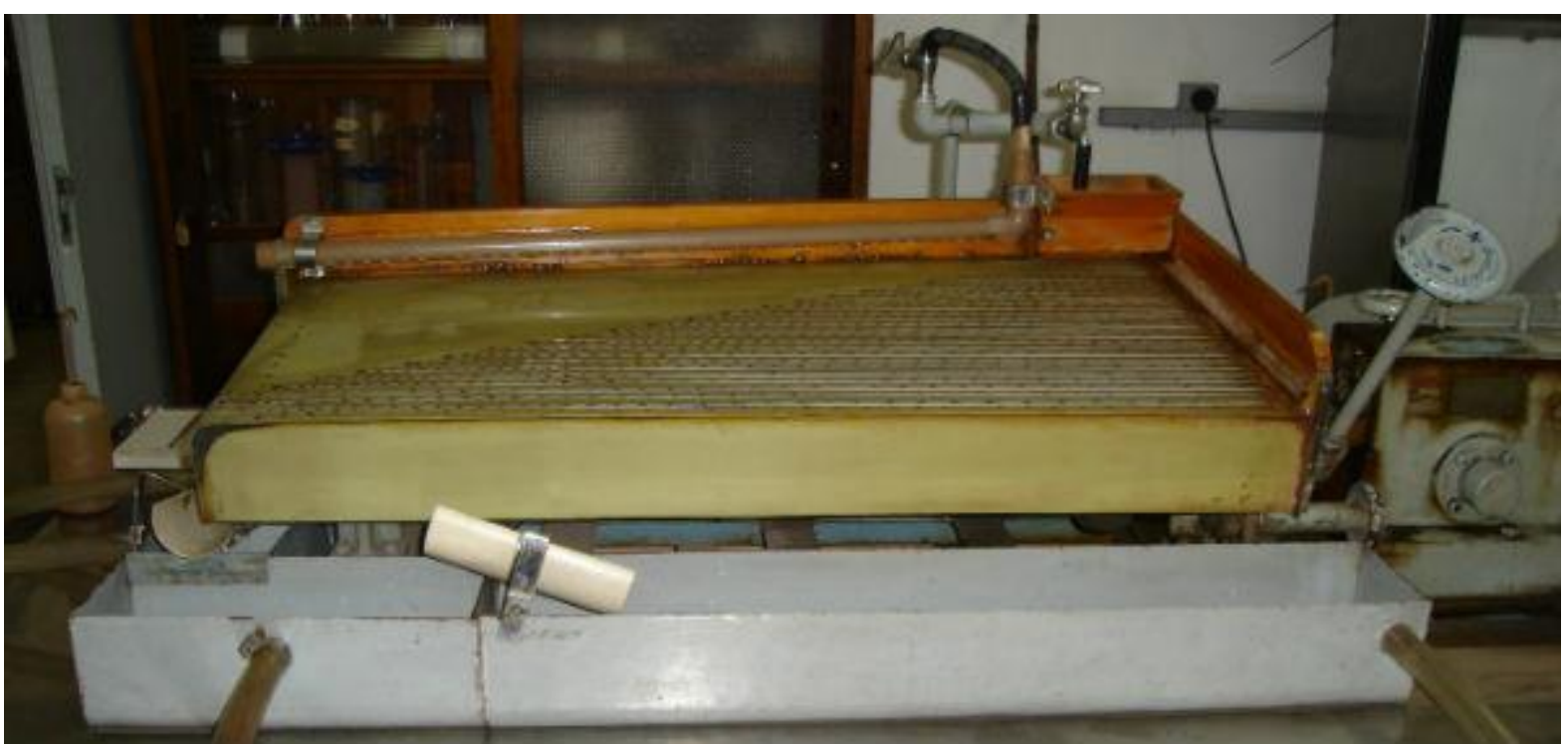

Fonte: IPT

Figura 3.3 - Mesa Vibratória.

Foi realizada a separação de elementos químicos metálicos e não metálicos para as três granulometrias do material com Mesh 9, 12 e 20, A mesa vibratória tem ao seu redor, recipientes coletores, que auxiliam na classificação, onde o material que escoa pela mesa fica retido em um dos três tipos, classificando assim o tipo de material como: pesado é o material que é arrastado por todo o rifle, médio é material intermediário que não foi arrastado por todo o rifle e leve o material que foi conduzido por cima do rifle. 


\subsubsection{Etapa de separação física (magnética e eletrostática)}

A rota selecionada para separação física de fração metálica e fração não metálica utilizando separadores, separador magnético da INBRAS-ERIEZ, modelo RE-ROLL 5-4-1, trabalhando a uma velocidade entre 60 e 100 RPM, com as placas de circuito impresso moídas e classificadas por peneiramento com granulometria 9 Mesh, figura 3.4;

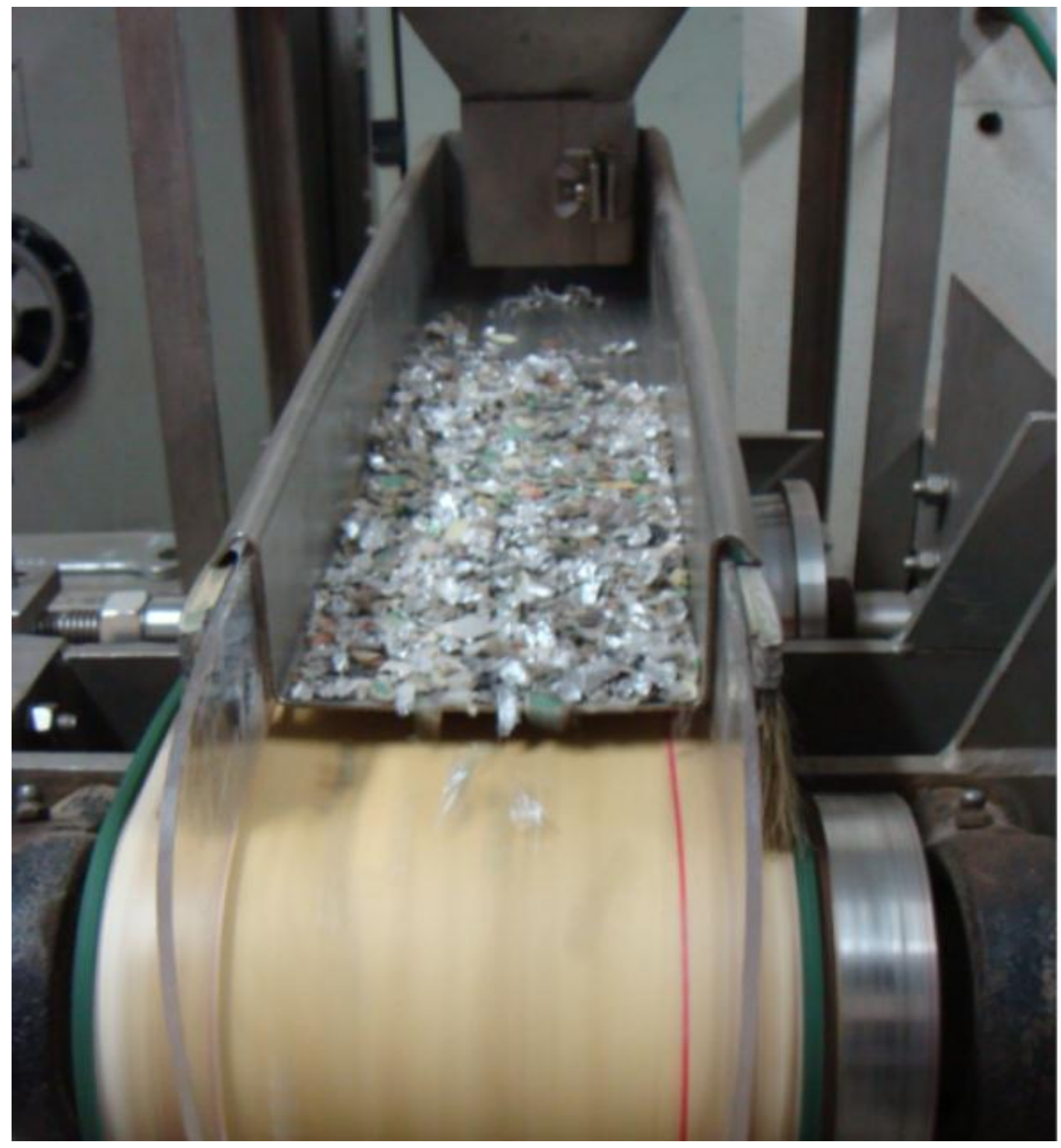

Fonte: Inbras

Figura 3.4 - Separador magnético. 
O separador eletrostático utilizado no processo de separação física é da INBRAS-ERIEZ, modelo ES-06/1L de alta potência ajustado a uma velocidade de 130 RPM, em destaque os 3 coletores de classificação, conforme ilustração da figura 3.5 ;

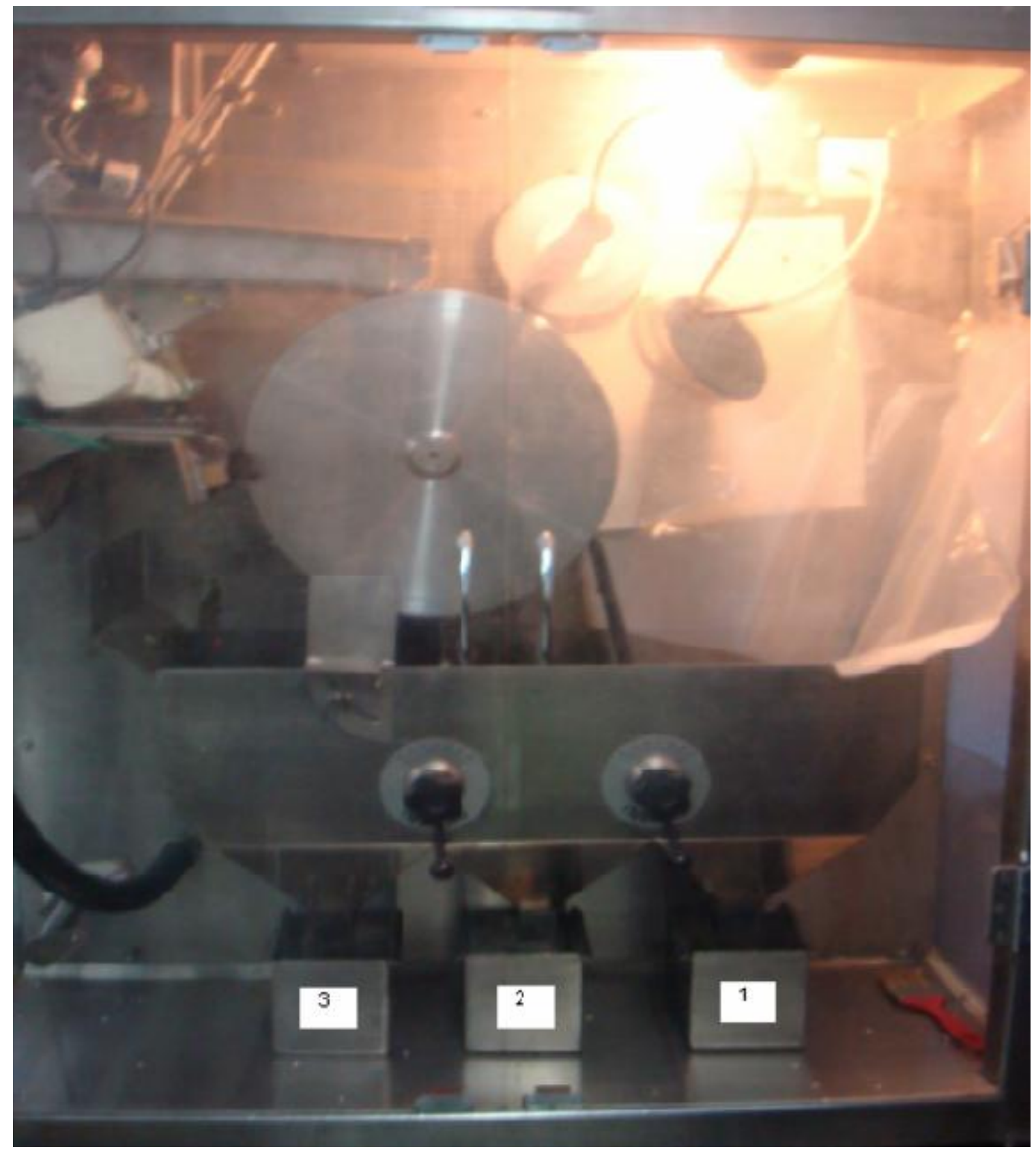

Fonte: Inbras

Figura 3.5 - Separador eletrostático. 
No processo de separação magnética e eletrostática, submeteu-se a amostra de resíduo retido na peneira de granulométrica 9 Mesh, posteriormente, as frações metálicas e não metálicas foram caracterizadas utilizando um Espectrômetro de Fluorescência de Raios X.

Uma amostra de 50 gramas de resíduo retido na peneira de granulométrica 9 Mesh foi submetida a diferentes condições de campos magnéticos (testes 1 a 5) e velocidades (RPM), conforme apresentado na Tabela 3.2. Os materiais que não foram retidos magneticamente foram submetidos ao separador eletrostático a uma velocidade de 130 RPM, com eficiência de 95\% de retenção.

Tabela 3.2 - Condições experimentais do processo de separação utilizando os separadores magnético e eletrostático.

\begin{tabular}{|c|c|c|c|c|}
\hline Teste & $\begin{array}{c}\text { Campo } \\
\text { Magnético }\end{array}$ & $\begin{array}{c}\text { Potência } \\
\text { (Gauss) }\end{array}$ & $\begin{array}{c}\text { Velocidade } \\
\text { do } \\
\text { separador } \\
\text { magnético } \\
\text { (RPM) }\end{array}$ & $\begin{array}{c}\text { Velocidade } \\
\text { do } \\
\text { separador } \\
\text { eletrostático } \\
\text { (RPM) }\end{array}$ \\
\hline 1 & Baixo & 1.000 & - & - \\
\hline 2 & Médio & 8.000 & - & - \\
\hline 3 & Alto & 21.000 & 100 & - \\
\hline 4 & Alto & 21.000 & 80 & - \\
\hline 5 & Alto & 21.000 & 60 & - \\
\hline 6 & nulo & - & - & 130 \\
\hline
\end{tabular}

Conforme Sampaio, 2004, a separação eletrostática é um processo que se baseia nas diferenças de algumas de suas propriedades, dos materiais tais como: condutibilidade elétrica, susceptibilidade em adquirir cargas elétricas superficiais, forma geométrica, densidade entre outras.

Para promover a separação é necessária a existência de dois fatores elétricos:

1) Ter um campo elétrico de intensidade suficiente para desviar uma partícula eletricamente carregada, quando em movimento na região do campo; 
2) Possuir carga elétrica superficial das partículas, ou polarização induzida, que lhes permitam sofrer a influência do campo elétrico.

A separação eletrostática está condicionada, entre outros fatores, ao mecanismo do sistema que produz as cargas superficiais nos diversos materiais a serem separados, como também à granulometria de liberação, que deve proporcionar uma partícula com carga suficiente para que haja uma atração efetiva por parte do campo elétrico aplicado.

A propriedade de um material que determina sua resposta a um campo magnético é chamada susceptibilidade magnética, baseados nisso os materiais ou minerais são classificados em duas categorias, aqueles que são atraídos pelo campo magnético e os que são repelidos por ele.

Portanto os materiais ferromagnéticos são atraídos fortemente pelo campo, os paramagnéticos são atraídos fracamente e os denominados diamagnéticos são repelidos pelo campo magnético.

O Separador Eletrostático do laboratório continha uma pista (ou calha) de condução do produto, com aproximadamente 10 centímetros largura, além de um eletrodo de corrente contínua que opera com a tensão de 0 a 30.000 VCC (Tensão Corrente Contínua) e um divisor ajustável, que serviu de divisória para que os materiais condutores e não-condutores fossem conduzidos aos coletores.

\subsubsection{Etapa de separação gravimétrica}

Para melhorar o processo de separação dos elementos químicos metálicos e não metálicos foram realizados experimentos utilizando fluidos com densidades diferentes tais como água, álcool etílico, clorofórmio e bromofórmio.

O clorofórmio da fabricante, MERCK, com grau de pureza: P.A. e o bromofórmio da fabricante CINÉTICA, com grau de pureza: 97\%, sendo ambos utilizados no método de separação por gravimetria da fração leve da fração pesada de cada malha classificada. O processo envolve o uso de líquido de alta densidade 
relativa. Este processo é utilizado para separação de partículas sólidas por meio de diferenças de densidades. As partículas pesadas se concentram no fundo do recipiente e as partículas leves flutuam na superfície, obtendo-se assim amostras de elementos metálicos e não metálicos.

A Tabela 3.3 apresenta alguns líquidos com suas respectivas densidades. Os líquidos utilizados para os ensaios experimentais foram o clorofórmio e bromofórmio, para verificação da separação das partes de placas de circuito impresso e plásticos/resina, das frações metálicas. Nestas experiências foram testadas as granulometrias Mesh 12, 20, 28, 35, 42, 60, 150 e Fundo (prato).

Tabela 3.3 - Densidades de alguns líquidos.

\begin{tabular}{ll}
\hline Líquido & Densidade $\left(\mathrm{g} \cdot \mathrm{cm}^{-3}\right)$ \\
\hline Água & 1,0 \\
Álcool etílico & 0,79 \\
$\mathrm{NaCl}+$ água & 1,2 \\
$\mathrm{CaCl}_{2}+$ água & 1,5 \\
Acetona:TBE = 0,27:1 & 2,5 \\
Clorofórmio & 1,48 \\
Bromofórmio & 2,89 \\
\hline
\end{tabular}

Fonte: Zhang, 1999.

A composição química das amostras de elementos metálicos e não metálicos foi analisada por Espectrometria de fluorescência de Raios $X$ por dispersão de energia.

Para a separação por gravimetria utilizou-se a solução de $50 \mathrm{~mL}$ de clorofórmio e cinco gramas de cada uma das granulometrias 12, 20, 28, 35, 42, 60, 150 Mesh e Fundo (prato). O mesmo procedimento foi adotado para a solução de bromofórmio. 
Para cada $5 \mathrm{~g}$ de amostra foram adicionadas $50 \mathrm{~mL}$ de clorofórmio ou de bromofórmio em um béquer, mantendo a amostra em contato com o líquido por 5 minutos. Após este tempo, observou-se duas fases distintas, sendo o material decantado no fundo do béquer (DEC) e material suspenso na superfície do líquido denso, denominado como sobrenadante, (SN). Separou-se o decantado (DEC) do sobrenadante ( $\mathrm{SN}$ ) em dois béqueres distintos, levando-os em seguida para a estufa para a secagem dos materiais DEC e SN. Este procedimento foi repetido para todas as granulometrias mencionadas acima. Na sequência, todas as amostras foram caracterizadas por Espectrometria de fluorescência de Raios $X$ por dispersão de energia.

\subsection{Segunda etapa do procedimento experimental}

Essa etapa envolveu os seguintes processos:

1. A trituração secundária (moagem) do material;

2. A separação gravimétrica;

3. A caracterização do material polimérico;

\subsubsection{Etapa de Trituração Secundária (moagem)}

Para trituração secundária foi utilizado um moinho de bolas da marca: Máquinas RENARD / ASTECMA, modelo: VMP.1, para fragmentar ainda mais o material, procurando-se obter uma melhor desagregação entre os materiais utilizados na construção da placa de circuito impresso. A trituração teve como objetivo fragmentar ainda mais o material, por ser bastante aglutinado em seu processo de construção para as granulometrias 60,150 Mesh e Fundo (prato).

Em um pote de plástico, foram acondicionados as esferas de cerâmica (alumina), e o resíduo da placa de circuito impresso, adicionou-se água deionizada, em quantidade suficiente para cobrir as esferas e o resíduo, pote foi vedado e fechado, com isto foi dado inicio ao processo de trituração secundária com duração de quatro horas. 
Ao término do processo de trituração secundária, foram retiradas as esferas do pote de plástico e o conteúdo (resíduo+água deionizada) e transferidos para um béquer, que foi colocado em uma estufa a uma temperatura de $80^{\circ} \mathrm{C}$, para evaporação da água e secagem do resíduo.

\subsubsection{Etapa de separação gravimétrica}

Esta etapa envolveu o material classificado como sobrenadante (fração leve) das três granulometrias 60, 150 Mesh e Fundo (prato), obtido no experimento de separação por gravimetria utilizando a solução de bromofórmio, realizado na primeira etapa do procedimento experimental.

Neste ensaio foram executados os processos de trituração secundária, na sequencia foi efetuada a separação gravimétrica utilizando a solução de bromofórmio e a caracterização quanto à composição química dos elementos metálicos e não metálicos, por Espectrometria de fluorescência de Raios $X$ por dispersão de energia (EDXRF).

Os procedimentos adotados neste experimento foram comuns às três granulometrias citadas, sendo que os resultados obtidos servirão de base ao comparar com os resultados obtidos na primeira etapa do procedimento experimental.

Foram colocados em três béquers distintos, os resíduos em quantidade de dois gramas de cada uma das granulometrias 60, 150 Mesh e Fundo (prato), adicionou-se solução de $40 \mathrm{~mL}$ de bromofórmio e submeteu-se ao aparelho de ultrassom da marca: UNIQUE, modelo: USC2850, por 20 minutos, com o objetivo de homogeneizar a suspensão.

Na sequência após a solução ter sido homogeneizada, foi transferida para um balão de vidro que ficou em decantação (repouso) na capela, por um período de sete dias. 
Após a separação por gravimetria o material foi colocado na mufla a uma temperatura de $100^{\circ} \mathrm{C}$ pelo período de uma hora, para completa evaporação do bromofórmio, após este período o material foi transferido para a estufa a $80^{\circ} \mathrm{C}$ por um período de sete dias, para completar a evaporação da solução.

\subsubsection{Etapa de caracterização do material polimérico}

Foram retiradas amostras do material sobrenadante das três granulometrias 60, 150 Mesh e Fundo (prato), que posteriormente foram submetidas à análise, de Espectrometria de fluorescência de Raios X por dispersão de energia (EDXRF) e Espectrometria de infravermelho.

\subsection{Caracterização das amostras}

A técnica de Espectrometria de fluorescência de Raios $X$ por dispersão de energia, Energy Dispersive X-ray Fluorescence Spectroscopy (EDXRF), foi usada para quantificação dos elementos presentes na composição química do resíduo, colocando-se o resíduo em pó sobre uma camada de filme de polipropileno com 5 microns de espessura e colocado em contato direto com o feixe de Raios X (EDX720, Shimadzu).

A técnica de Espectrometria de infravermelho com transformada de Fourier, Fourier Transform Infrared (FT-IR), foi usada para identificação de compostos orgânicos (polímeros) contidos na amostra dos resíduos da placa de circuito impresso, sendo usado para isto um espectrômetro Thermo Nicolet Nexus 400 FT$\mathrm{IR}$, o resíduo em pó foi disperso em pastilhas de $\mathrm{KBr}$ com grau de espectrometria.

\subsubsection{Espectrometria de fluorescência de Raios X}

O princípio de funcionamento da fluorescência de Raios $X$, conforme figura 3.6, baseia-se na interação da radiação com os níveis eletrônicos dos átomos da amostra. Os elétrons presentes nos orbitais mais próximos do núcleo são excitados e arrancados da camada eletrônica em função da radiação incidente. Com esse desequilíbrio eletrônico, algum elétron de uma camada mais próxima, perde a 
energia e decai para a camada de onde o primeiro elétron se ejetou. Esse mecanismo de decaimento acontece devido à liberação de energia do elétron mais externo. A energia liberada por esse elétron, para promover seu decaimento característico de cada elemento químico. Assim pode-se discriminar os Raios $\mathrm{X}$ liberados pelos elementos químicos presentes na amostra. Esses Raios $X$ liberados são conhecidos como fluorescência, sendo posteriormente detectado, analisado e quantificado para dar informações sobre o átomo que o originou (BONTURIM, 2012).

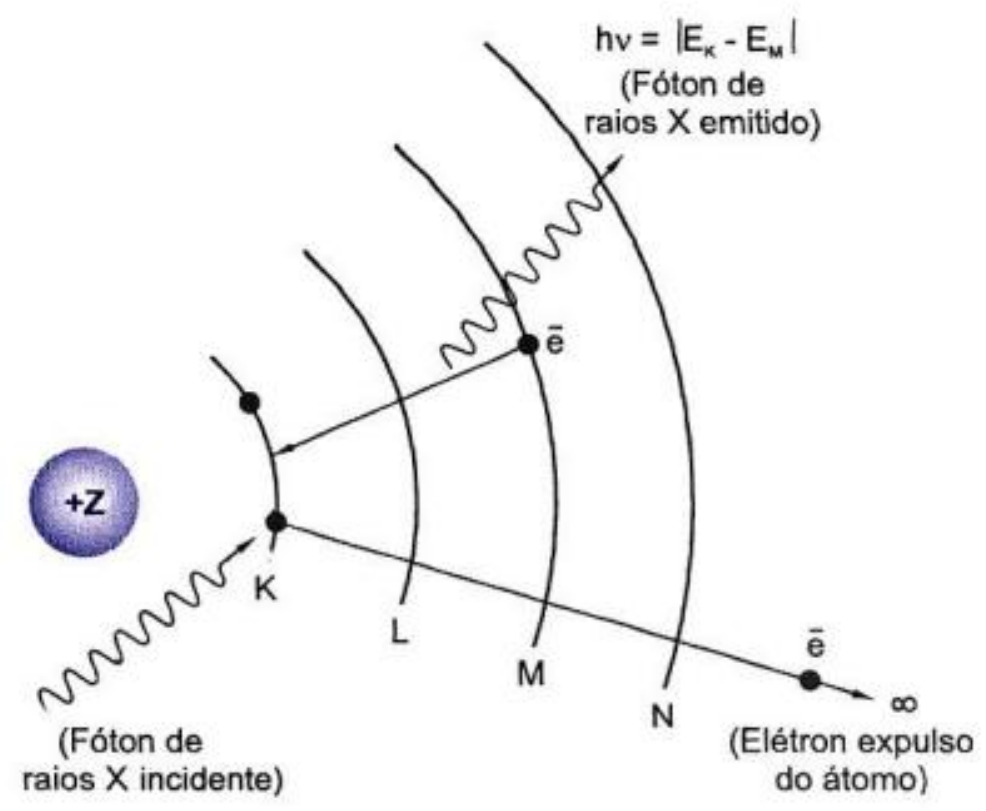

Figura 3.6 - Mecanismo de geração de fluorescência de Raios X.

O princípio de funcionamento é a emissão de radiação eletromagnética, característica. Os elétrons mais externos ao receberem energia de uma fonte externa (calor do plasma de argônio, no caso), são excitados e promovidos a um estado mais energético, porém, instável. A tendência é que esses elétrons voltem ao estado inicial emitindo o excesso de energia na forma de radiação característica. Da mesma forma que na Fluorescência de Raios X, essa radiação é característica de cada elemento químico presente na amostra. 
Podem ser excitados átomos neutros ou íons e essa condição pode ser utilizada para o estabelecimento das condições de análise da amostra.

Nesta técnica, as amostras são, normalmente, analisadas na forma de solução líquida. Porém, com acessórios especiais (laser ablation, por exemplo), amostras sólidas também podem ser analisadas sem a necessidade de solubilizá-las.

Pela alta energia associada ao plasma de argônio (7000 K), quase toda a Tabela Periódica pode ser quantificada.

Por ser baseado no fenômeno da emissão atômica, os equipamentos podem operar no modo seqüencial ou simultâneo, isto é, determinando um elemento por vez (sequencial) ou diversos ao mesmo tempo (simultâneo).

\subsubsection{Espectrometria de infravermelho com (FT-IR)}

\subsubsection{Caracterização dos polímeros}

A técnica de Espectrometria de infravermelho com transformada de Fourier, Fourier Transform Infrared (FT-IR), foi usada para identificação de compostos orgânicos (polímeros) contidos na amostra dos resíduos da placa de circuito impresso, sendo que dentre os materiais utilizados na confecção das placas de circuito impresso, está a resina epóxi caracterizada com um dos polímeros termofixos.

A resina epóxi representa uma das classes mais versáteis, apresentando uma combinação singular de propriedades, como resistência à tração e tenacidade, resistência química, à umidade e à corrosão, boas propriedades térmicas, adesivas e elétricas. Isto geralmente não é encontrado em outros materiais poliméricos, sendo sua aplicação atrativa quando se deseja produzir materiais de engenharia.

Em função de apresentar facilidade durante o processamento, baixa contração e boa fluidez, normalmente a resina epóxi mais utilizada em diversas aplicações é o diglicidil éter de bisfenol A (DGEBA), tendo a estrutura apresentada pela figura 3.7. (JAIN et al., 2003) 


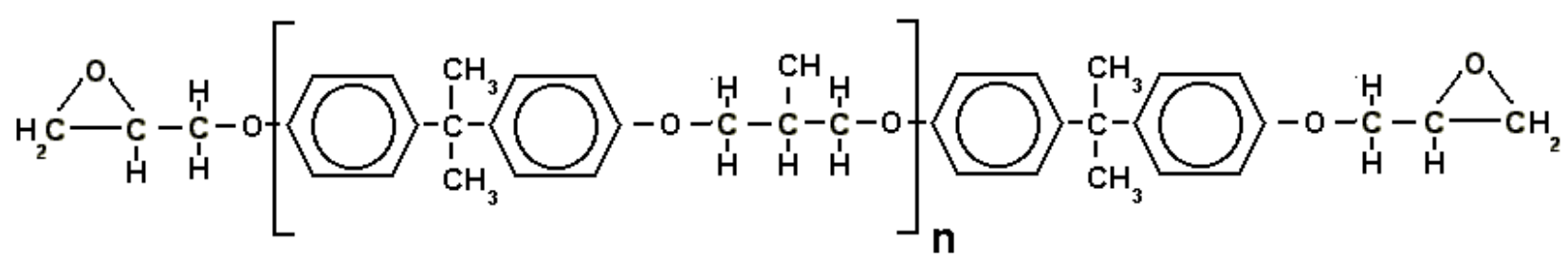

Figura 3.7 - Estrutura química do diglicidil éter de bisfenol A (DGEBA). (DEAN, 1999)

A espectroscopia na região de infravermelho (IV) é uma técnica que permite a análise orgânica qualitativa, sendo amplamente utilizadas nas áreas de química de produtos naturais, síntese e transformações orgânicas.

São, também, de alta relevância na determinação da pureza e quantificação de substâncias orgânicas, bem como no controle e acompanhamento de reações e processos de separação. A espectroscopia na região de infravermelho envolve a análise de informação acerca da energia absorvida por uma amostra. Normalmente, temos a representação da \% de transmitância em função do número de onda $\left(\mathrm{cm}^{-1}\right)$.

A espectroscopia de infravermelho transformada de Fourier fornece evidencias da presença de vários grupos funcionais, na estrutura orgânica devido à interação das moléculas ou átomos com a radiação eletromagnética em um processo de vibração e absorção molecular. As ligações covalentes que constituem as moléculas orgânicas estão em movimentos axiais e angulares, constante. A radiação no infravermelho faz com que átomos e grupos de átomos de compostos orgânicos vibrem com amplitude aumentada ao redor das ligações covalentes que os ligam.

O processo é quantizado, porém o espectro vibracional costuma aparecer como uma serie de bandas, porque a cada mudança de nível de energia vibracional corresponde uma série de mudanças de níveis de energia rotacional, desta forma, as linhas se sobrepõem dando origem às bandas observadas no espectro, conforme figura 3.8.

$\mathrm{Na}$ prática um procedimento padronizado estabelece uma forma rápida e simples para comprovar a identidade de uma amostra por meio da comparação, de seu espectro infravermelho com o espectro gerado na ausência da amostra.

Baseando-se no fato de que as ligações químicas das substâncias possuem frequências de vibração específicas, as quais correspondem a níveis de energia da 
molécula (chamados nesse caso de níveis vibracionais). Tais frequências dependem da forma da superfície de energia potencial da molécula, da geometria molecular, das massas dos átomos e eventualmente do acoplamento vibrônico.

A radiação no infravermelho na presença da amostra faz com que, a luz infravermelha, ao incidir numa molécula provoca a excitação e se a molécula receber radiação eletromagnética com 'exatamente' a mesma energia de uma dessas vibrações, isto é quando a energia radiante corresponde à diferença entre dois níveis energéticos vibracionais, então a luz será absorvida, quando a molécula sofrer uma variação no seu momento dipolar durante essa vibração.

O espectrômetro registra o resultado na forma de uma banda de absorção. Um espectrômetro de grande sensibilidade é o espectrômetro com transformada de Fourier (FTIR), que emprega um interferômetro de Michelson, que tem a finalidade de dividir o feixe da radiação da fonte de infravermelho de tal forma que ele reflita simultaneamente a partir de um espelho em movimento e de um espelho fixo. Os feixes refletidos voltam a se combinar e passam através da amostra para o detector e são reproduzidos na forma de um gráfico de tempo contra a intensidade do sinal denominado de interferograma. (UFPA, 2013).

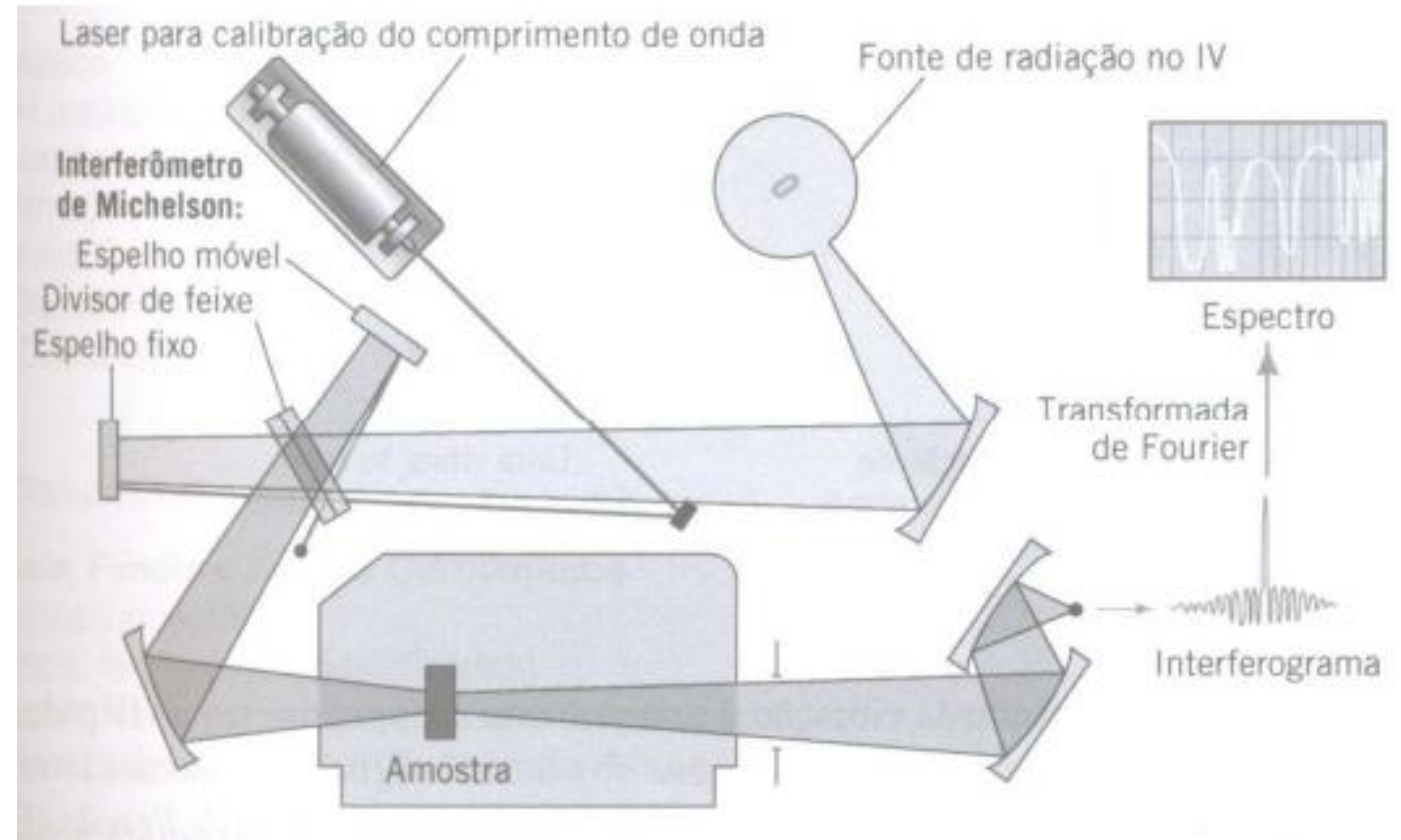

Figura 3.8 - Espectrômetro com transformada de Fourier .(Solomons, 2005). 


\section{RESULTADOS E DISCUSSÃO}

\subsection{Moagem e Classificação Granulométrica.}

Os resultados da moagem e classificação granulométrica das placas de circuito impresso descaracterizadas estão apresentadas na figura 4.1.
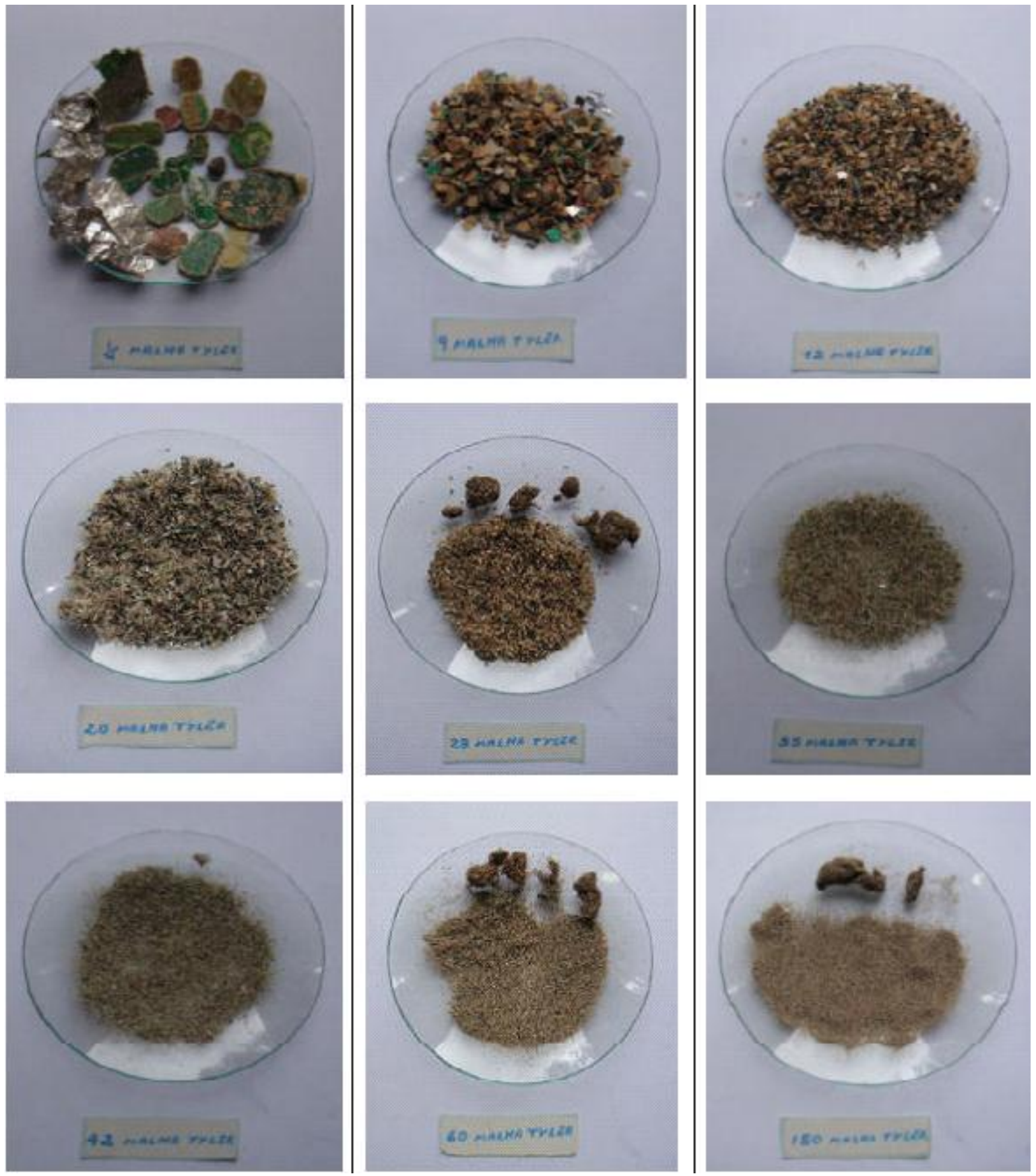

Figura 4.1 - Classificação granulométrica das placas de circuito impresso moídas 
A Tabela 4.1 apresenta os resultados obtidos na separação granulométrica, sendo apresentada a quantidade mássica em porcentagem, do material retido em cada uma das peneiras utilizadas para a classificação granulométrica.

Tabela 4.1 - Quantidade mássica após a classificação granulométrica.

\begin{tabular}{|c|c|}
\hline Mesh & $\begin{array}{c}\text { Quantidade } \\
\text { retida em } \\
\text { cada peneira } \\
(\%)\end{array}$ \\
\hline 9 & 18,77 \\
\hline 20 & 18,02 \\
\hline FUNDO & 11,48 \\
\hline 12 & 11,26 \\
\hline 35 & 10,35 \\
\hline 150 & 8,79 \\
\hline 28 & 7,39 \\
\hline $1 / 4$ & 6,20 \\
\hline 60 & 5,30 \\
\hline 42 & 2,44 \\
\hline
\end{tabular}

Pode-se observar pelos resultados obtidos na tabela 4.1 , que as granulometrias 9 e 20 Mesh, apresentaram cada uma delas uma porcentagem próxima a $18 \%$ em massa, quantidade superior às demais peneiras, caracterizando ser um material de difícil desagregação.

Para as granulometrias mais finas representadas pelas peneiras de granulometria Fundo e 150 Mesh, nas respectivas quantidades retidas em cada uma destas granulometrias foi de aproximadamente $11 \%$ em massa e $8 \%$ em massa, proporcionalmente o material destas granulometrias representam um valor próximo $20 \%$ em massa de todo o material triturado. Sendo que para se obter uma melhor desagregação, pode-se repetir este processo utilizando o material de maior granulometria.

Verifica-se que quanto menor a granulometria, o material se encontra desagregado, favorecendo, a possibilidade de sucesso na separação dos materiais metálicos e não metálicos. 
Os materiais metálicos contêm em sua composição elementos, que possibilitam uma razoável condução de calor e eletricidade, enquanto que os materiais não metálicos não contêm em sua composição propriedades de metal, são frequentemente utilizados como isolantes.

\subsection{Separação física por densidade}

Foram realizados os ensaios de separação de metálicos e não metálicos utilizando a mesa vibratória para as amostras com granulometrias 9, 12 e 20 Mesh. Observou-se que a separação das frações pesadas (metálicos) das placas de circuito impresso, não foi satisfatória devido ao fato do material ser muito denso. $\mathrm{A}$ alta densidade dos materiais não favoreceu o seu arraste pela água, apresentando grande aderência das partículas na mesa e impedindo que o material escoasse pelas canaletas (rifles da mesa), (Figura 4.2).

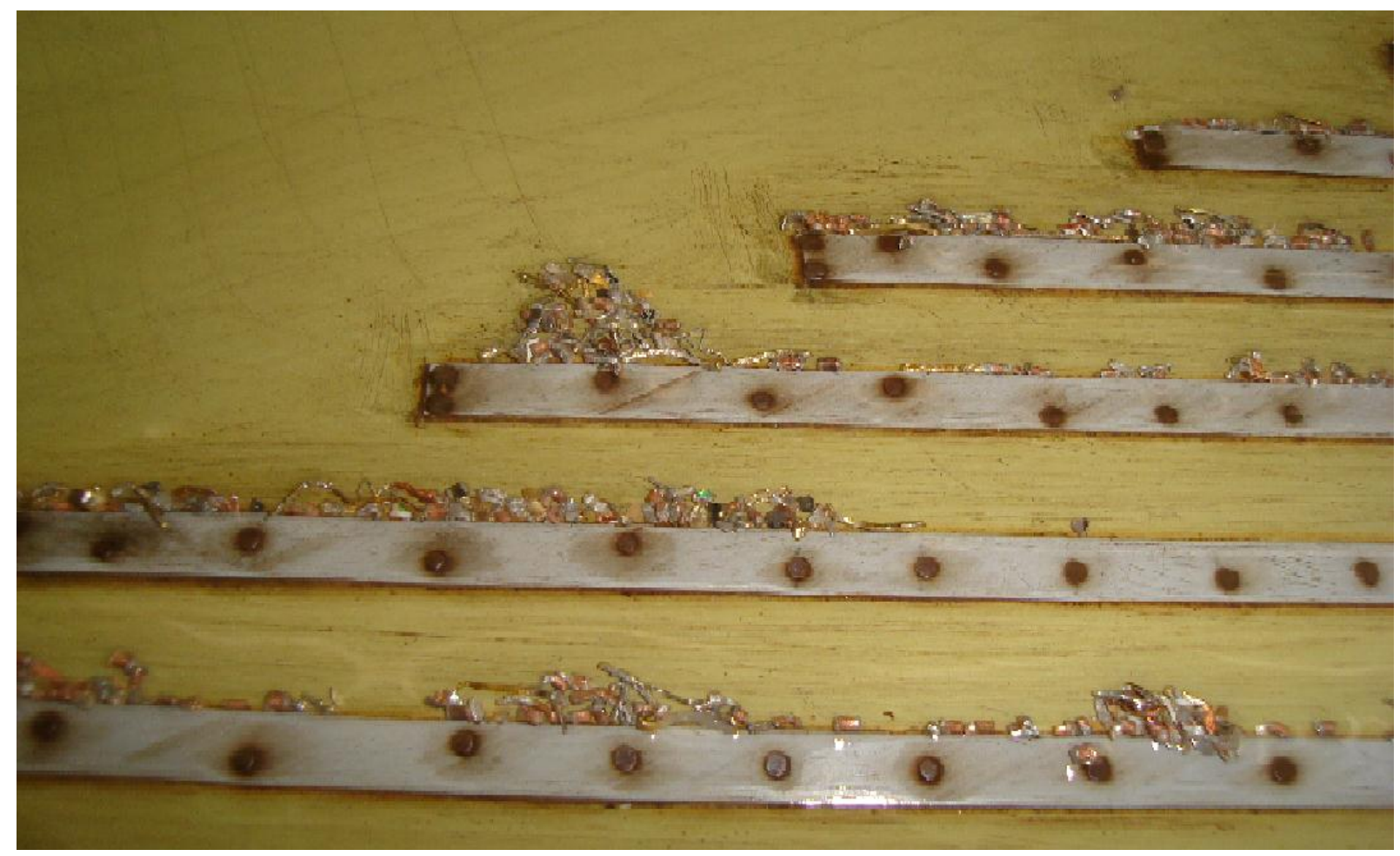

Fonte: IPT

Figura 4.2 - Material em formato lamelar nos rifles da mesa vibratória. 
As densidades dos elementos químicos identificados por Fluorescência de Raios X estão apresentadas na tabela 4.2.

Tabela 4.2 - Densidades dos elementos químicos presentes nas amostras 9,12 e 20 Mesh.

\begin{tabular}{|c|c|c|}
\hline Denominação & Elemento & Densidade $\left(\mathrm{g} / \mathrm{cm}^{3}\right)$ \\
\hline Bromo & $\mathrm{Br}$ & 3,12 \\
\hline Calcio & $\mathrm{Ca}$ & 1,55 \\
\hline Cobre & $\mathrm{Cu}$ & 8,92 \\
\hline Ferro & $\mathrm{Fe}$ & 7,87 \\
\hline Manganês & $\mathrm{Mn}$ & 7,47 \\
\hline Níquel & $\mathrm{Ni}$ & 8,90 \\
\hline Chumbo & $\mathrm{Pb}$ & 11,3 \\
\hline Enxofre & $S$ & 1,96 \\
\hline Silicio & $\mathrm{Si}$ & 2,33 \\
\hline Estanho & Sn & 7,31 \\
\hline Zinco & $\mathrm{Zn}$ & 7,14 \\
\hline
\end{tabular}

O fato dos materiais apresentarem formatos de fibras ou lamelas, ou seja, uma característica achatada em forma de laminas dificultou o deslizamento e o escoamento do material, permanecendo retidas nas canaletas (rifles).

Como resultado dessa característica lamelar, a qual pode-se notar por meio da figura 4.2, para o material retido nas peneiras de granulometrias 9, 12 e 20 Mesh, o resultado experimental no ensaio da mesa vibratória, não foi adequado para este tipo de experimento. Para as demais granulometrias, Fundo (prato), 150, 60, 42, 35 e 28 Mesh, não foram submetidas ao teste da mesa vibratória, por não apresentarem as características necessárias para esse tipo de equipamento. $O$ ideal para este tipo de equipamento é trabalhar com, partículas de morfologia granular e materiais com baixa densidade.

A partir dos resultados das análises por $\mathrm{FRX}$, determinaram-se as quantidades mássicas presentes nas frações 9, 12 e 20 Mesh, das placas de circuito impresso retidas nos coletores da mesa vibratória apresentadas na Tabela 4.3. 
Tabela 4.3 - Quantidade mássicas das frações (9, 12 e 20 Mesh) das placas de circuito impresso retidas nos coletores da mesa vibratória.

\begin{tabular}{cc}
\hline ELEMENTO QUÍMICO & QUANTIDADE $(\mathbf{m g})$ \\
\hline $\mathrm{Br}$ & 60 \\
$\mathrm{Ca}$ & 2367 \\
$\mathrm{Cu}$ & 519 \\
$\mathrm{Fe}$ & 4815 \\
$\mathrm{Mn}$ & 59 \\
$\mathrm{Ni}$ & 72 \\
$\mathrm{~Pb}$ & 150 \\
$\mathrm{~S}$ & 880 \\
$\mathrm{Si}$ & 4995 \\
$\mathrm{Sn}$ & 89 \\
$\mathrm{Zn}$ & 562 \\
\hline
\end{tabular}

A partir dos resultados da tabela 4.4, nota-se que dentre os elementos químicos de maiores densidades, tais como o Cobre, Ferro, Níquel, Chumbo, Estanho e Zinco, foram identificadas em maior quantidade mássica presente nos coletores. Tal resultado mostra que este tipo de equipamento, não foi apropriado para a operação de elementos metálicos e não metálicos, pois o $\mathrm{Ca}, \mathrm{Si}$, de menores densidades apresentaram maiores retenções nos coletores.

\subsection{Separação Magnética e Eletrostática}

O ensaio de separação física realizada no separador magnético teve como objetivo identificar a fração metálica que sofre atração. Foram realizados cinco testes, experimentais de separação de materiais metálicos e de não metálicos, utilizando 50g, da amostra granulométrica de 9 Mesh. 
Neste experimento apenas a granulometria 9 Mesh foi submetida à separação física, por apresentar características mais adequadas aos equipamentos usados neste ensaio. Objetivo deste ensaio Foi identificar o quanto das frações metálicas presentes, de acordo com as propriedades magnéticas e eletrostáticas, são atraídos pelo campo magnético do equipamento e como condutores elétricos.

Os materiais das demais granulometrias $(12,20,28,35,42,60,150$ Mesh e Fundo), não puderam ser submetidos aos testes desse ensaio de separação física, em função da limitação do equipamento em trabalhar com granulometrias finas, não sendo compatíveis com as velocidades permitidas, pelos equipamentos de separação.

Conforme tabela 4.4, são apresentados os resultados obtidos com a utilização dos vários campos magnéticos e as respectivas quantidades obtidas em cada um dos testes, para o Teste_1 utilizou-se um tambor com baixo campo magnético, para o Teste_2 utilizou-se um tambor com médio campo magnético. Para os Testes (3, 4 e 5), utilizou-se um separador magnético (Inbrás, modelo RE-ROLL 5-4-1) de tambor com campo magnético, variando-se apenas a velocidade. Para o teste 6 utilizou-se o separador eletrostático.

Tabela 4.4 - Quantidade da fração metálica com granulometria 9 Mesh, resultante do processo de separação física.

\begin{tabular}{|c|c|}
\hline Teste & $\begin{array}{c}\text { Quantidade } \\
\text { separada } \\
(\mathrm{g})\end{array}$ \\
\hline 1 & 3,0890 \\
\hline 2 & 1,9115 \\
\hline 3 & 1,8444 \\
\hline 4 & 1,5572 \\
\hline 5 & 0,3899 \\
\hline 6 & 39,1000 \\
\hline
\end{tabular}

Observa-se na tabela 4.4, o melhor resultado de separação foi no teste 1 , pois obteve-se a maior quantidade de material da fração metálica magnetizável com campo magnético baixo. 
$\mathrm{Na}$ tabela 4.5 são apresentados os parâmetros utilizados nos equipamentos de separação magnética e eletrostática.

Tabela 4.5 - Condições empregadas na separação magnética e eletrostática.

\begin{tabular}{|c|c|c|c|c|}
\hline & Campo Magnético & $\begin{array}{c}\text { Potência } \\
\text { (Gauss) }\end{array}$ & $\begin{array}{c}\text { Velocidade } \\
\text { do separador } \\
\text { magnético } \\
\text { (RPM) }\end{array}$ & $\begin{array}{c}\text { do } \\
\text { separador } \\
\text { eletrostático } \\
\text { (RPM) }\end{array}$ \\
\hline 1 & Baixo & 1.000 & - & - \\
\hline 2 & Médio & 8.000 & - & - \\
\hline 3 & Alto & 21.000 & 100 & - \\
\hline 4 & Alto & 21.000 & 80 & - \\
\hline 5 & Alto & 21.000 & 60 & - \\
\hline 6 & nulo & - & - & 130 \\
\hline
\end{tabular}

Os testes de 1 a 5 , representam a separação magnética com suas respectivas variações de potência de campo magnético e velocidade do equipamento, sendo que em cada um dos testes, o material, identificado como magnetizável em um teste, não era utilizado no teste seguinte, por isso a variação dos resultados na coluna quantidade separada da tabela 4.4 , indicando como sendo o melhor resultado o teste_1, para isto, entenda-se que o material de partida era menor ao ser utilizado no teste subsequente.

O material resultante no coletor, após os testes de 1 a 5 , foi caracterizado como material não magnetizável, sendo utilizado no Teste_6, no equipamento separador eletrostático.

Pode-se notar na Figura 3.5, apresentada no item 3.2.4. Etapa de separação física (magnética e eletrostática), que ilustra alguns fragmentos da placa espalhados, fora dos coletores, mostrando que os materiais muito finos, não são efetivos ao serem utilizados em separadores eletrostáticos.

O material classificado como não magnético, foi submetido ao separador eletrostático, referenciado na tabela 4.5 , no Teste 6 . O equipamento possui 3 coletores, Figura 3.5, apresentada no item 3.2.4. Etapa de separação física 
(magnética e eletrostática), contando-se da esquerda para a direita, ficam na seguinte disposição (3) - (2) - (1).

No coletor 3 ficou depositado o material não condutor.

No coletor 2 ficou depositado o material misto (médio condutor).

No coletor 1 ficou depositado o material condutor.

Observou-se que aproximadamente $90 \%$ do material submetido a este ensaio ficou retido no coletor (3) o qual representa o material não condutor, sendo que o material retido nesse coletor apresentou a quantidade de 39,1g.

Do material com granulometria de 9 Mesh, foram retiradas três amostras de placas de circuito impresso, identificados como Amostras A, B e C, cujas foram caracterizadas por Fluorescência de Raios X (FRX), (Tabelas 4.6).

Tabela 4.6 - Caracterização química e quantidades dos elementos químicos presentes na amostra de granulometria 9 Mesh.

\begin{tabular}{|c|c|c|c|c|c|c|c|c|}
\hline $\begin{array}{c}\text { Elemento } \\
\text { quimico }\end{array}$ & Tipo & $\begin{array}{c}\text { Amostra - A - } \\
\text { Quantidade } \\
(\%)\end{array}$ & $\begin{array}{c}\text { Amostra - B- } \\
\text { Quantidade } \\
(\%)\end{array}$ & $\begin{array}{c}\text { Amostra - C - } \\
\text { Quantidade } \\
(\%)\end{array}$ & $\begin{array}{c}\text { Somatória } \\
\text { das } \\
\text { amostras } \\
A+B+C \\
(\%) \\
\end{array}$ & $\begin{array}{c}\text { Quantidade } \\
\text { Média } \\
(\%) \\
\end{array}$ & $\begin{array}{c}\text { Somatória } \\
\text { das } \\
\text { amostras } \\
A+B+C \\
(\mathrm{mg})\end{array}$ & $\begin{array}{c}\text { Quantidade } \\
\text { Média } \\
\text { (mg) }\end{array}$ \\
\hline $\mathrm{Al}$ & Metais & 44,708 & 4,097 & 4,034 & 52,839 & 17,613 & 0,0562 & 0,009899 \\
\hline $\mathrm{Au}$ & Metais & 0 & 0,272 & 3,453 & 3,725 & 1,863 & 0,0562 & 0,001047 \\
\hline $\mathrm{Ba}$ & Metais & 0 & 16,828 & 0,444 & 17,272 & 8,636 & 0,0562 & 0,004853 \\
\hline $\mathrm{Br}$ & Não Metais & 1,007 & 1,619 & 5,249 & 7,875 & 2,625 & 0,0562 & 0,001475 \\
\hline $\mathrm{Ca}$ & Metais & 18,844 & 1,895 & 0,587 & 21,326 & 7,109 & 0,0562 & 0,003995 \\
\hline Co & Metais & 0 & 0 & 0,091 & 0,091 & 0,091 & 0,0562 & 0,000051 \\
\hline $\mathrm{Cu}$ & Metais & 1,011 & 45,71 & 44,723 & 91,444 & 30,481 & 0,0562 & 0,017131 \\
\hline $\mathrm{Fe}$ & Metais & 4,996 & 0 & 0 & 4,996 & 4,996 & 0,0562 & 0,002808 \\
\hline$K$ & Metais & 2,734 & 0 & 0,418 & 3,152 & 1,576 & 0,0562 & 0,000886 \\
\hline $\mathrm{Mn}$ & Metais & 0,416 & 0 & 0 & 0,416 & 0,416 & 0,0562 & 0,000234 \\
\hline $\mathrm{Ni}$ & Metais & 0 & 1,968 & 33,31 & 35,278 & 17,639 & 0,0562 & 0,009913 \\
\hline$S$ & Não Metais & 5,123 & 4,512 & 0 & 9,635 & 4,818 & 0,0562 & 0,002707 \\
\hline $\mathrm{Si}$ & Semimetais & 20,027 & 13,485 & 7,69 & 41,202 & 13,734 & 0,0562 & 0,007719 \\
\hline Sn & Metais & 0 & 9,559 & 0 & 9,559 & 9,559 & 0,0562 & 0,005372 \\
\hline $\mathrm{Sr}$ & Metais & 0 & 0,055 & 0 & 0,055 & 0,055 & 0,0562 & 0,000031 \\
\hline $\mathrm{Zr}$ & Metais & 1,133 & 0 & 0 & 1,133 & 1,133 & 0,0562 & 0,000637 \\
\hline
\end{tabular}


Os elementos presentes na amostra 9 Mesh, foram classificados conforme suas propriedades magnéticas, demonstrado (Tabela 4.7).

Tabela 4.7 - Classificação magnética dos elementos presentes na amostra com granulométrica de 9 Mesh.

\begin{tabular}{|c|c|c|}
\hline Elemento & Tipo & Classificaçäo magnética \\
\hline $\mathrm{Al}$ & metal & paramagnético \\
\hline $\mathrm{Au}$ & metal & diamagnético \\
\hline $\mathrm{Ba}$ & metal & paramagnético \\
\hline $\mathrm{Br}$ & não metal & paramagnético \\
\hline $\mathrm{Ca}$ & metal & paramagnético \\
\hline $\mathrm{Co}$ & metal & Ferromagnético \\
\hline $\mathrm{Gu}$ & metal & diamagnético \\
\hline $\mathrm{Fe}$ & metal & Ferromagnético \\
\hline $\mathrm{K}$ & metal & paramagnético \\
\hline $\mathrm{Mn}$ & metal & paramagnético \\
\hline $\mathrm{Ni}$ & metal & Ferromagnético \\
\hline $\mathrm{S}$ & não metal & diamagnético \\
\hline $\mathrm{Si}$ & semimetal & diamagnético \\
\hline $\mathrm{Sn}$ & metal & diamagnético \\
\hline $\mathrm{Sr}$ & metal & paramagnético \\
\hline $\mathrm{Zr}$ & metal & paramagnético \\
\hline
\end{tabular}

Observa-se na tabela 4.7 que a maioria dos elementos químicos é classificada como paramagnéticos.

Ao analisar os elementos presentes nas amostras, pode-se observar que os caracterizados como metálicos, apresentaram maior ocorrência em relação aos demais, dentre estes elementos os que apresentam maior concentração foram o Alumínio, Cobre e Níquel, sendo que os três elementos apresentam respectivamente a concentração de $17 \%, 30 \%$ e $17 \%$ em massa.

A separação foi efetiva ao comparar a quantidade do material de partida $47,8920 \mathrm{~g}$, com a quantidade de material caracterizado como magnetizável que foi de $8,7920 \mathrm{~g}$ e a quantidade de material caracterizado como eletrostático que foi de $39,1000 \mathrm{~g}$, neste montante é composto de $18 \%$ de material magnetizável e $82 \%$ de material eletrostático.

$\mathrm{Na}$ separação física utilizando a mesa vibratória as granulometrias utilizadas foram 9, 12 e 20 Mesh, os elementos de maior de maior quantidade presencial foram - Cobre e o Ferro. No processo de separação magnética e eletrostática a granulometria utilizada foi $9 \mathrm{Mesh}$, os elementos que apresentaram maior quantidade 
mássica foram o Alumínio, Cobre e Níquel. Em ambos os processos citados, o elemento Cobre, está presente e em maior quantidade.

\subsection{Separação Gravimétrica}

A separação gravimétrica foi efetuada para as granulometrias $12,20,28,35$, 42, 60, 150 Mesh e Fundo (prato), utilizando as soluções de Clorofórmio e Bromofórmio.

\subsubsection{Separação por densidade com solução de Clorofórmio}

A Tabela 4.8 apresenta os resultados obtidos dos ensaios gravimétricos utilizando o líquido denso clorofórmio com a finalidade de separar a fração pesada (metálicos) e fração leve (não metálicos) das granulometrias de 12 Mesh ao Fundo (prato).

Tabela 4.8 - Resultados dos testes gravimétricos para as granulometrias 12 mesh ao Fundo (prato).

\begin{tabular}{ccccc}
\hline $\begin{array}{c}\text { Granulometrias } \\
\text { MESH }\end{array}$ & $\begin{array}{c}\text { Medida inicial } \\
\text { (gramas) }\end{array}$ & $\begin{array}{c}\text { Fração leve } \\
\text { (gramas) }\end{array}$ & $\begin{array}{c}\text { Fração pesada } \\
\text { (gramas) }\end{array}$ & $\begin{array}{c}\text { Perdas } \\
\text { (gramas) }\end{array}$ \\
\hline 12 & 5,000 & 1,210 & 3,733 & 0,057 \\
20 & 5,000 & 0,157 & 4,829 & 0,014 \\
28 & 5,185 & 1,489 & 3,608 & 0,088 \\
35 & 5,195 & 0,420 & 4,763 & 0,012 \\
42 & 5,090 & 0,883 & 4,197 & 0,010 \\
60 & 5,180 & 0,933 & 3,919 & 0,328 \\
150 & 4,995 & 0,507 & 3,814 & 0,674 \\
Fundo (prato) & 5,010 & 0,309 & 4,602 & 0,099 \\
\hline
\end{tabular}

Dos resultados da composição química das placas de circuito impresso das frações pesadas (metálicos) e leves (não metálicos) das granulometrias entre 12 Mesh e Fundo (prato) foi efetuada uma seleção de três granulometrias, sendo; 60,150 Mesh e Fundo (prato). Estas três granulometrias foram escolhidas por serem 
as mais finas e por estarem as partículas desaglomeradas. Os resultados destas 3 granulometrias estão apresentados nas Tabelas 4.9, 4.10 e 4.11.

Tabela 4.9 - Elementos químicos presentes na amostra da granulometria 60 Mesh.

\begin{tabular}{|c|c|c|c|c|c|c|c|c|c|}
\hline $\begin{array}{c}\text { Elemento } \\
\text { quimico }\end{array}$ & $\begin{array}{l}\text { Material de } \\
\text { Partida } \\
\text { (g) }\end{array}$ & $\begin{array}{c}\text { Total do } \\
\text { Sobrenadante } \\
\text { (g) }\end{array}$ & $\begin{array}{c}\text { Sobrenadante } \\
(\%)\end{array}$ & $\begin{array}{c}\text { Quantidade do } \\
\text { Sobrenadante } \\
\text { (g) }\end{array}$ & $\begin{array}{c}\text { Total do } \\
\text { Decantado } \\
\text { (g) }\end{array}$ & $\begin{array}{c}\text { Decantado } \\
(\%)\end{array}$ & $\begin{array}{l}\text { Quantidade do } \\
\text { Decantado } \\
\text { (g) }\end{array}$ & $\begin{array}{l}\text { Somatória das } \\
\text { Quantidades } \\
\text { do } \\
\text { sobrenadante } \\
\text { e do } \\
\text { decantado } \\
\text { (g) } \\
\end{array}$ & $\begin{array}{c}\text { Elemento } \\
\text { quimico } \\
\text { Participação } \\
\text { Representativa } \\
(\%)\end{array}$ \\
\hline$A C$ & 5,1800 & 0,9330 & 0,1460 & 0,0014 & 0 & 0 & 0 & 0,0014 & 0,03 \\
\hline $\mathrm{Ag}$ & 5,1800 & 0 & 0 & 0 & 3,9190 & 0,1360 & 0,0053 & 0,0053 & 0,10 \\
\hline $\mathrm{Al}$ & 5,1800 & - & - & - & - & - & - & - & - \\
\hline $\mathrm{Au}$ & 5,1800 & - & - & - & - & - & - & - & - \\
\hline $\mathrm{Ba}$ & 5,1800 & 0 & 0 & 0 & 3,9190 & 0,6120 & 0,0240 & 0,0240 & 0,46 \\
\hline $\mathrm{Bi}$ & 5,1800 & 0 & 0 & 0 & 3,9190 & 0,1390 & 0,0054 & 0,0054 & 0,11 \\
\hline $\mathrm{Br}$ & 5,1800 & 0,9330 & 58,9040 & 0,5496 & 0 & 0 & 0 & 0,5496 & 10,61 \\
\hline $\mathrm{Ca}$ & 5,1800 & 0,9330 & 4,0500 & 0,0378 & 0 & 0 & 0 & 0,0378 & 0,73 \\
\hline $\mathrm{Cl}$ & 5,1800 & 0,9330 & 15,2170 & 0,1420 & 0 & 0 & 0 & 0,1420 & 2,74 \\
\hline Co & 5,1800 & - & . & - & - & - & - & . & - \\
\hline $\mathrm{Cr}$ & 5,1800 & 0 & 0 & 0 & 3,9190 & 0,1000 & 0,0039 & 0,0039 & 0,08 \\
\hline $\mathrm{Cu}$ & 5,1800 & 0,9330 & 0,5870 & 0,0055 & 0 & 0 & 0 & 0,0055 & 0,11 \\
\hline $\mathrm{Fe}$ & 5,1800 & 0,9330 & 5,7260 & 0,0534 & 0 & 0 & 0 & 0,0534 & 1,03 \\
\hline I & 5,1800 & 0 & 0 & 0 & 3,9190 & 0,4630 & 0,0181 & 0,0181 & 0,35 \\
\hline K & 5,1800 & - & - & - & - & - & - & - & - \\
\hline $\mathrm{Mg}$ & 5,1800 & - & - & - & - & - & . & - & . \\
\hline $\mathrm{Mn}$ & 5,1800 & 0,9330 & 0,1420 & 0,0013 & 3,9190 & 0,9240 & 0,0362 & 0,0375 & 0,72 \\
\hline $\mathrm{Nb}$ & 5,1800 & 0 & 0 & 0 & 3,9190 & 0,0480 & 0,0019 & 0,0019 & 0,04 \\
\hline $\mathrm{Ni}$ & 5,1800 & 0 & 0 & 0 & 3,9190 & 0,3330 & 0,0131 & 0,0131 & 0,25 \\
\hline P & 5,1800 & 0,9330 & 1,3230 & 0,0123 & 0 & 0 & 0 & 0,0123 & 0,24 \\
\hline $\mathrm{Pb}$ & 5,1800 & 0,9330 & 0,3930 & 0,0037 & 3,9190 & 1,2860 & 0,0504 & 0,0541 & 1,04 \\
\hline$S$ & 5,1800 & 0,9330 & 0,7350 & 0,0069 & 3,9190 & 0,8430 & 0,0330 & 0,0399 & 0,77 \\
\hline $\mathrm{Sb}$ & 5,1800 & 0,9330 & 6,5200 & 0,0608 & 3,9190 & 1,0460 & 0,0410 & 0,1018 & 1,97 \\
\hline $\mathrm{Si}$ & 5,1800 & 0,9330 & 3,2470 & 0,0303 & 0 & 0 & 0 & 0,0303 & 0,58 \\
\hline Sn & 5,1800 & - & - & - & - & - & . & - & . \\
\hline $\mathrm{Sr}$ & 5,1800 & 0 & 0 & 0 & 3,9190 & 0,1590 & 0,0062 & 0,0062 & 0,12 \\
\hline $\mathrm{Ti}$ & 5,1800 & 0,9330 & 3,1290 & 0,0292 & 0 & 0 & 0 & 0,0292 & 0,56 \\
\hline $\mathrm{Zn}$ & 5,1800 & 0,9330 & 0,2480 & 0,0023 & 0 & 0 & 0 & 0,0023 & 0,04 \\
\hline $\mathrm{Zr}$ & 5,1800 & 0 & 0 & 0 & 3,9190 & 0,1740 & 0,0068 & 0,0068 & 0,13 \\
\hline
\end{tabular}

O elemento que apresentou maior concentração, dentre o presentes, foi o $\mathrm{Br}$ com uma participação representativa na amostra, respectiva de 10,61\% em massa, sendo que para este valor poderá ocorrer uma redução no valor, em decorrencia da evaporação.

Ao analisar os valores da tabela 4.9 após a separação por densidade nota-se que $18 \%$ em massa corresponde ao material sobrenadante, $75 \%$ em massa do 
material decantado e a diferenca de 7\% em massa do material se incorporou a solução de cloroformio, ficando em suspensão na solução.

Tabela 4.10 - Elementos químicos presentes na amostra da granulometria 150 Mesh.

\begin{tabular}{|c|c|c|c|c|c|c|c|c|c|}
\hline $\begin{array}{c}\text { Elemento } \\
\text { quimico }\end{array}$ & $\begin{array}{c}\text { Material } \\
\text { de Partida } \\
\text { (g) }\end{array}$ & $\begin{array}{c}\text { Total do } \\
\text { Sobrenadante } \\
\text { (g) }\end{array}$ & $\begin{array}{c}\text { Sobrenadante } \\
(\%) \\
\end{array}$ & $\begin{array}{c}\text { Quantidade do } \\
\text { Sobrenadante } \\
\text { (g) }\end{array}$ & $\begin{array}{c}\text { Total do } \\
\text { Decantado } \\
\text { (g) }\end{array}$ & $\begin{array}{c}\text { Decantado } \\
(\%)\end{array}$ & $\begin{array}{c}\text { Quantidade do } \\
\text { Decantado } \\
\text { (g) }\end{array}$ & $\begin{array}{c}\text { Somatória das } \\
\text { Quantidade do } \\
\text { sobrenadante } \\
\text { e do } \\
\text { decantado } \\
\text { (g) }\end{array}$ & $\begin{array}{c}\text { Elemento } \\
\text { quimico } \\
\text { Participação } \\
\text { Representativa } \\
(\%)\end{array}$ \\
\hline$A C$ & 4,995 & 0,5070 & 0,1200 & 0,0006 & 0 & 0 & 0 & 0,0006 & 0,01 \\
\hline $\mathrm{Ag}$ & 4,995 & 0 & 0 & 0 & 3,8140 & 0,1260 & 0,0048 & 0,0048 & 0,10 \\
\hline $\mathrm{Al}$ & 4,995 & 0,5070 & 10,0790 & 0,0511 & 3,8140 & 15,7780 & 0,6018 & 0,6529 & 13,07 \\
\hline $\mathrm{Au}$ & 4,995 & - & - & - & - & - & - & - & - \\
\hline $\mathrm{Ba}$ & 4,995 & 0 & 0 & 0 & 3,8140 & 2,3640 & 0,0902 & 0,0902 & 1,81 \\
\hline $\mathrm{Bi}$ & 4,995 & - & - & - & - & - & - & - & - \\
\hline $\mathrm{Br}$ & 4,995 & 0,5070 & 47,6270 & 0,2415 & 3,8140 & 6,1790 & 0,2357 & 0,4771 & 9,55 \\
\hline $\mathrm{Ca}$ & 4,995 & 0,5070 & 5,3610 & 0,0272 & 3,8140 & 4,8600 & 0,1854 & 0,2125 & 4,26 \\
\hline $\mathrm{Cl}$ & 4,995 & 0,5070 & 10,8490 & 0,0550 & 0 & 0 & 0 & 0,0550 & 1,10 \\
\hline $\mathrm{C}_{0}$ & 4,995 & - & - & - & - & - & - & - & - \\
\hline $\mathrm{Cr}$ & 4,995 & 0 & 0 & 0 & 3,8140 & 0,1090 & 0,0042 & 0,0042 & 0,08 \\
\hline $\mathrm{Cu}$ & 4,995 & 0,5070 & 0,8720 & 0,0044 & 3,8140 & 9,2710 & 0,3536 & 0,3580 & 7,17 \\
\hline $\mathrm{Fe}$ & 4,995 & 0,5070 & 9,7230 & 0,0493 & 0 & 0 & 0 & 0,0493 & 0,99 \\
\hline 1 & 4,995 & - & - & - & - & - & - & - & - \\
\hline K & 4,995 & - & - & - & - & - & - & - & - \\
\hline $\mathrm{Mg}$ & 4,995 & - & - & - & - & - & - & - & - \\
\hline $\mathrm{Mn}$ & 4,995 & 0,5070 & 0,2430 & 0,0012 & 3,8140 & 1,1480 & 0,0438 & 0,0450 & 0,90 \\
\hline $\mathrm{Nb}$ & 4,995 & 0 & 0 & 0 & 3,8140 & 0,0250 & 0,0010 & 0,0010 & 0,02 \\
\hline $\mathrm{Ni}$ & 4,995 & 0 & 0 & 0 & 3,8140 & 0,2740 & 0,0105 & 0,0105 & 0,21 \\
\hline P & 4,995 & 0,5070 & 1,8290 & 0,0093 & 0 & 0 & 0 & 0,0093 & 0,19 \\
\hline $\mathrm{Pb}$ & 4,995 & 0,5070 & 0,3930 & 0,0020 & 3,8140 & 1,8650 & 0,0711 & 0,0731 & 1,46 \\
\hline$S$ & 4,995 & 0,5070 & 0,7790 & 0,0039 & 3,8140 & 0,5580 & 0,0213 & 0,0252 & 0,51 \\
\hline $\mathrm{Sb}$ & 4,995 & 0,5070 & 3,5650 & 0,0181 & 3,8140 & 0,7360 & 0,0281 & 0,0461 & 0,92 \\
\hline $\mathrm{Si}$ & 4,995 & 0,5070 & 5,8680 & 0,0298 & 0 & 0 & 0 & 0,0298 & 0,60 \\
\hline Sn & 4,995 & 0 & 0 & 0 & 3,8140 & 3,3470 & 0,1277 & 0,1277 & 2,56 \\
\hline $\mathrm{Sr}$ & 4,995 & 0 & 0 & 0 & 3,8140 & 0,1070 & 0,0041 & 0,0041 & 0,08 \\
\hline $\mathrm{Ti}$ & 4,995 & 0,5070 & 2,2780 & 0,0115 & 3,8140 & 1,0010 & 0,0382 & 0,0497 & 1,00 \\
\hline $\mathrm{Zn}$ & 4,995 & 0,5070 & 0,4130 & 0,0021 & 3,8140 & 2,2190 & 0,0846 & 0,0867 & 1,74 \\
\hline $\mathrm{Zr}$ & 4,995 & 0 & 0 & 0 & 3,8140 & 0,3020 & 0,0115 & 0,0115 & 0,23 \\
\hline
\end{tabular}

Os elementos que apresentaram maior concentração, dentre o presentes, foram o Alumínio, o Bromo, o Cobre em relação ao material de partida, com uma participação representativa na amostra, respectiva de 13,07\%, 9,55\% e 7,17\% em massa. 
Ao analisar os valores da tabela 4.10, após a separação por densidade notase que $10 \%$ corresponde ao material sobrenadante, $76 \%$ em massa do material decantado e a diferenca de $14 \%$ em massa do material se incorporou a solução de cloroformio, ficando em suspensão na solução.

Tabela 4.11 - Elementos químicos presentes na amostra da granulometria Fundo (prato).

\begin{tabular}{|c|c|c|c|c|c|c|c|c|c|}
\hline $\begin{array}{l}\text { Elemento } \\
\text { quimico }\end{array}$ & $\begin{array}{c}\text { Material } \\
\text { de Partida } \\
\text { (g) }\end{array}$ & $\begin{array}{c}\text { Total do } \\
\text { Sobrenadante } \\
\text { (g) }\end{array}$ & $\begin{array}{c}\text { Sobrenadante } \\
(\%)\end{array}$ & $\begin{array}{c}\text { Quantidade do } \\
\text { Sobrenadante } \\
\text { (g) }\end{array}$ & $\begin{array}{c}\text { Total do } \\
\text { Decantado } \\
(\mathrm{g})\end{array}$ & $\begin{array}{c}\text { Decantado } \\
(\%)\end{array}$ & $\begin{array}{l}\text { Quantidade } \\
\text { do } \\
\text { Decantado } \\
\text { (g) }\end{array}$ & $\begin{array}{l}\text { Somatória das } \\
\text { Quantidades do } \\
\text { sobrenadante e } \\
\text { do decantado } \\
\text { (g) }\end{array}$ & $\begin{array}{c}\text { Elemento } \\
\text { quimico } \\
\text { Participação } \\
\text { Representativa } \\
(\%) \\
\end{array}$ \\
\hline$A C$ & 5,010 & - & - & - & . & - & - & - & - \\
\hline $\mathrm{Ag}$ & 5,010 & 0 & 0 & 0 & 4,6020 & 0,1190 & 0,0055 & 0,0055 & 0,11 \\
\hline Al & 5,010 & 0,3090 & 20,3440 & 0,0629 & 4,6020 & 12,6695 & 0,5831 & 0,6459 & 12,89 \\
\hline $\mathrm{Au}$ & 5,010 & - & - & - & - & - & - & - & - \\
\hline $\mathrm{Ba}$ & 5,010 & 0,3090 & 2,5560 & 0,0079 & 4,6020 & 1,4685 & 0,0676 & 0,0755 & 1,51 \\
\hline $\mathrm{Bi}$ & 5,010 & - & - & - & - & - & - & - & - \\
\hline $\mathrm{Br}$ & 5,010 & 0,3090 & 35,4210 & 0,1095 & 4,6020 & 4,7280 & 0,2176 & 0,3270 & 6,53 \\
\hline $\mathrm{Ca}$ & 5,010 & 0,3090 & 8,1940 & 0,0253 & 4,6020 & 25,1740 & 1,1585 & 1,1838 & 23,63 \\
\hline $\mathrm{Cl}$ & 5,010 & 0,3090 & 6,0890 & 0,0188 & 0 & 0 & 0 & 0,0188 & 0,38 \\
\hline $\mathrm{Co}_{0}$ & 5,010 & - & - & - & - & - & - & - & - \\
\hline $\mathrm{Cr}$ & 5,010 & - & - & - & - & - & - & - & - \\
\hline $\mathrm{Cu}$ & 5,010 & 0,3090 & 1,5040 & 0,0046 & 4,6020 & 4,6105 & 0,2122 & 0,2168 & 4,33 \\
\hline $\mathrm{Fe}$ & 5,010 & 0,3090 & 8,4420 & 0,0261 & 4,6020 & 11,7365 & 0,5401 & 0,5662 & 11,30 \\
\hline 1 & 5,010 & - & - & - & - & - & - & - & - \\
\hline K & 5,010 & . & - & - & - & - & - & . & - \\
\hline $\mathrm{Mg}$ & 5,010 & 0,3090 & 0,6550 & 0,0020 & 0 & 0 & 0 & 0,0020 & 0,04 \\
\hline $\mathrm{Mn}$ & 5,010 & 0 & 0 & 0 & 4,6020 & 0,2225 & 0,0102 & 0,0102 & 0,20 \\
\hline $\mathrm{Nb}$ & 5,010 & - & - & - & - & - & - & - & - \\
\hline $\mathrm{Ni}$ & 5,010 & 0,3090 & 0,0490 & 0,0002 & 4,6020 & 0,2680 & 0,0123 & 0,0125 & 0,25 \\
\hline$P$ & 5,010 & - & - & - & - & - & - & - & . \\
\hline $\mathrm{Pb}$ & 5,010 & 0,3090 & 0,5420 & 0,0017 & 4,6020 & 1,9530 & 0,0899 & 0,0916 & 1,83 \\
\hline$S$ & 5,010 & 0,3090 & 0,7570 & 0,0023 & 4,6020 & 0,1745 & 0,0080 & 0,0104 & 0,21 \\
\hline$S b$ & 5,010 & 0,3090 & 0,2040 & 0,0006 & 4,6020 & 0,1160 & 0,0053 & 0,0060 & 0,12 \\
\hline $\mathrm{Si}$ & 5,010 & 0,3090 & 14,1000 & 0,0436 & 4,6020 & 29,7670 & 1,3699 & 1,4134 & 28,21 \\
\hline Sn & 5,010 & 0 & 0 & 0 & 4,6020 & 2,4425 & 0,1124 & 0,1124 & 2,24 \\
\hline $\mathrm{Sr}$ & 5,010 & 0,3090 & 0,0460 & 0,0001 & 4,6020 & 0,2365 & 0,0109 & 0,0110 & 0,22 \\
\hline $\mathrm{Ti}$ & 5,010 & 0 & 0 & 0 & 4,6020 & 0,6785 & 0,0312 & 0,0312 & 0,62 \\
\hline$Z n$ & 5,010 & 0,3090 & 0,2330 & 0,0007 & 4,6020 & 0,9510 & 0,0438 & 0,0445 & 0,89 \\
\hline $\mathrm{Zr}$ & 5,010 & 0,3090 & 0,0540 & 0,0002 & 4,6020 & 0,1845 & 0,0085 & 0,0087 & 0,17 \\
\hline
\end{tabular}

Os elementos que apresentaram maior concentração, dentre o presentes, foram o Alumínio, o Calcio, o Ferro e o Silicio em relação ao material de partida, com uma participação representativa na amostra, respectiva de 12,89\%, 23,63\%, 11,30\% e $28,21 \%$ em massa; 
Ao analisar os valores da tabela 4.11 após a separação por densidade nota-se que $0,05 \%$ em massa, corresponde ao material sobrenadante, $92 \%$ em massa do material decantado e a diferenca de $7,5 \%$ em massa do material se incorporou a solução de cloroformio, ficando em suspensão na solução.

\subsubsection{Separação por densidade com solução de Bromofórmio}

A Tabela 4.12 apresenta os resultados obtidos dos ensaios gravimétricos utilizando o líquido bromofórmio afim de separar a fração pesada (metálicos) e fração leve (não metálicos) das granulometrias de 12 Mesh ao Fundo (prato).

Tabela 4.12 - Resultados dos testes gravimétricos para as granulometrias 12 Mesh ao Fundo (prato).

\begin{tabular}{|c|c|c|c|c|}
\hline $\begin{array}{c}\text { Faixa em } \\
\text { MESH }\end{array}$ & $\begin{array}{c}\text { Medida } \\
\text { inicial } \\
\text { (gramas) }\end{array}$ & $\begin{array}{c}\text { Fração } \\
\text { leve } \\
\text { (gramas) }\end{array}$ & $\begin{array}{c}\text { Fração } \\
\text { pesada } \\
\text { (gramas) }\end{array}$ & $\begin{array}{c}\text { Perdas } \\
\text { (gramas) }\end{array}$ \\
\hline 12 & 5,0089 & 2,0177 & 2,9455 & 0,0457 \\
\hline 20 & 5,0042 & 1,9628 & 2,8936 & 0,1478 \\
\hline 28 & 5,0112 & 2,6049 & 2,2499 & 0,1564 \\
\hline 35 & 5,0035 & 2,6321 & 2,2181 & 0,1533 \\
\hline 42 & 5,006 & 1,9688 & 2,8245 & 0,2127 \\
\hline 60 & 5,0049 & 2,3812 & 2,343 & 0,2807 \\
\hline 150 & 5,0073 & 4,014 & 0,9861 & 0,0072 \\
\hline Fundo (prato) & 5,0066 & 4,1515 & 0,7988 & 0,0563 \\
\hline
\end{tabular}

As mesmas granulometrias 60, 150 Mesh e Fundo (prato), foram selecionadas, para esta rota por separação por densidade, utilizando a solução de bromofórmio. Os resultados obtidos por esta rota de separação estão apresentados nas tabelas $4.13,4.14$ e 4.15 . 
Tabela 4.13 - Elementos químicos presentes na amostra da granulometria 60 Mesh.

\begin{tabular}{|c|c|c|c|c|c|c|c|c|c|}
\hline $\begin{array}{l}\text { Elemento } \\
\text { quimico }\end{array}$ & $\begin{array}{c}\text { Material de } \\
\text { Partida } \\
\text { (g) }\end{array}$ & $\begin{array}{c}\text { Total do } \\
\text { Sobrenadante } \\
\text { (g) }\end{array}$ & $\begin{array}{c}\text { Sobrenadante } \\
(\%)\end{array}$ & $\begin{array}{c}\text { Quantidade do } \\
\text { Sobrenadante } \\
\text { (g) }\end{array}$ & $\begin{array}{c}\text { Total do } \\
\text { Decantado } \\
\text { (g) }\end{array}$ & $\begin{array}{c}\text { Decantado } \\
(\%)\end{array}$ & $\begin{array}{c}\text { Quantidade do } \\
\text { Decantado } \\
\text { (g) }\end{array}$ & $\begin{array}{l}\text { Somatória das } \\
\text { Quantidade do } \\
\text { sobrenadante e } \\
\text { do decantado } \\
\text { (g) }\end{array}$ & $\begin{array}{c}\text { Elemento } \\
\text { quimico } \\
\text { Participação } \\
\text { Representativa } \\
(\%) \\
\end{array}$ \\
\hline $\mathrm{Ag}$ & 50049 & 0 & 0 & 0 & 23430 & (1210 & 00028 & 00038 & 006 \\
\hline $\mathrm{Al}$ & 5,0049 & 2,3812 & 20,3440 & 0,4844 & 2,3430 & 10,3930 & 0,2435 & 0,7279 & 14,54 \\
\hline $\mathrm{Ba}$ & 5,0049 & 2,3812 & 2,5560 & 0,0609 & 2,3430 & 2,3630 & 0,0554 & 0,1162 & 2,32 \\
\hline $\mathrm{Br}$ & 5,0049 & 2,3812 & 48,7680 & 1,1613 & 2,3430 & 1,2560 & 0,0294 & 1,1907 & 23,79 \\
\hline $\mathrm{Ca}$ & 5,0049 & 2,3812 & 13,6330 & 0,3246 & 2,3430 & 1,1540 & 0,0270 & 0,3517 & 7,03 \\
\hline $\mathrm{Cu}$ & 5,0049 & 2,3812 & 0,6430 & 0,0153 & 2,3430 & 27,7850 & 0,6510 & 0,6663 & 13,31 \\
\hline $\mathrm{Fe}$ & 5,0049 & 2,3812 & 6,6340 & 0,1580 & 2,3430 & 37,9490 & 0,8891 & 1,0471 & 20,92 \\
\hline $\mathrm{Mn}$ & 5,0049 & 2,3812 & 0,2160 & 0,0051 & 2,3430 & 3,0170 & 0,0707 & 0,0758 & 1,52 \\
\hline $\mathrm{Ni}$ & 5,0049 & 0 & 0 & 0 & 2,3430 & 0,5560 & 0,0130 & 0,0130 & 0,26 \\
\hline $\mathrm{Pb}$ & 5,0049 & 2,3812 & 0,7320 & 0,0174 & 2,3430 & 2,4600 & 0,0576 & 0,0751 & 1,50 \\
\hline$S$ & 5,0049 & 2,3812 & 0,5540 & 0,0132 & 0 & 0 & 0 & 0,0132 & 0,26 \\
\hline $\mathrm{Sb}$ & 5,0049 & 2,3812 & 4,7820 & 0,1139 & 0 & 0 & 0 & 0,1139 & 2,28 \\
\hline $\mathrm{Si}$ & 5,0049 & 2,3812 & 19,2040 & 0,4573 & 2,3430 & 2,5360 & 0,0594 & 0,5167 & 10,32 \\
\hline Sn & 5,0049 & 0 & 0 & 0 & 2,3430 & 4,7290 & 0,1108 & 0,1108 & 2,21 \\
\hline $\mathrm{Sr}$ & 5,0049 & 2,3812 & 0,2420 & 0,0058 & 2,3430 & 0,0980 & 0,0023 & 0,0081 & 0,16 \\
\hline $\mathrm{Ti}$ & 5,0049 & 2,3812 & 3,9650 & 0,0944 & 2,3430 & 0,6480 & 0,0152 & 0,1096 & 2,19 \\
\hline $\mathrm{Zn}$ & 5,0049 & 2,3812 & 0,4510 & 0,0107 & 2,3430 & 4,3190 & 0,1012 & 0,1119 & 2,24 \\
\hline $\mathrm{Zr}$ & 5,0049 & 2,3812 & 0,1750 & 0,0042 & 2,3430 & 0,2310 & 0,0054 & 0,0096 & 0,19 \\
\hline
\end{tabular}

Destacam-se pela concentração os elementos químicos $\mathrm{Al}, \mathrm{Br}, \mathrm{Ca}$ e $\mathrm{Si}$, com uma participação representativa na amostra, respectiva de 14,54\%, 23,79\%, 7,03\% e $10,32 \%$ em massa.

Ao comparar os resultados dos ensaios para granulometria 60 Mesh os resultados utilizando as duas soluções de clorofórmio e bromoformio, pode-se verificar entre os elementos presentes nas duas amostras de sobrenadantes da granulometria 60 Mesh, a quantidade porcentual dos elementos $\mathrm{Al}, \mathrm{Br}$, Ca e Si é maior quando utilizado o bromoformio em relação ao clorofórmio, exceção apenas para $\mathrm{S}$ e Sb, verificou-se menor quantidade mássica presente na amostra.

Pode-se observar que ao comparar os elementos da amostra de decantados de granulometria $60 \mathrm{Mesh}$, que a quantidade porcentual de presença dos elementos é maior quando utilizado o bromoformio em relação ao clorofórmio, exceção apenas para Sr que apresentou uma redução do porcentual da quantidade mássica. 
Tabela 4.14 - Elementos químicos presentes na amostra da granulometria 150 Mesh.

\begin{tabular}{|c|c|c|c|c|c|c|c|c|c|}
\hline $\begin{array}{c}\text { Elemento } \\
\text { quimico }\end{array}$ & $\begin{array}{c}\begin{array}{c}\text { Material } \\
\text { de Partida } \\
\text { (g) }\end{array} \\
\end{array}$ & $\begin{array}{c}\text { Total do } \\
\text { Sobrenadante } \\
\text { (g) }\end{array}$ & $\begin{array}{c}\text { Sobrenadante } \\
(\%)\end{array}$ & $\begin{array}{c}\text { Quantidade do } \\
\text { Sobrenadante } \\
\text { (g) }\end{array}$ & $\begin{array}{c}\text { Total do } \\
\text { Decantado } \\
\text { (g) }\end{array}$ & $\begin{array}{c}\text { Decantado } \\
(\%)\end{array}$ & $\begin{array}{c}\text { Quantidade } \\
\text { do } \\
\text { Decantado } \\
\text { (g) }\end{array}$ & $\begin{array}{c}\text { Somatória } \\
\text { das } \\
\text { Quantidades } \\
\text { do } \\
\text { sobrenadante } \\
\text { e do } \\
\text { decantado } \\
\text { (g) } \\
\end{array}$ & $\begin{array}{c}\text { Elemento } \\
\text { quimico } \\
\text { Participação } \\
\text { Representativa } \\
(\%)\end{array}$ \\
\hline $\mathrm{Ag}$ & 5,0073 & 0 & 0 & 0 & 0,9861 & 0,5440 & 0,0054 & 0,0054 & 0,11 \\
\hline $\mathrm{Al}$ & 5,0073 & 0 & 0 & 0 & 0,9861 & 15,4100 & 0,1520 & 0,1520 & 3,03 \\
\hline $\mathrm{Ba}$ & 5,0073 & 4,0140 & 3,9060 & 0,1568 & 0,9861 & 4,6070 & 0,0454 & 0,2022 & 4,04 \\
\hline $\mathrm{Br}$ & 5,0073 & 4,0140 & 51,2550 & 2,0574 & 0,9861 & 3,4830 & 0,0343 & 2,0917 & 41,77 \\
\hline $\mathrm{Ca}$ & 5,0073 & 4,0140 & 15,4220 & 0,6190 & 0 & 0 & 0 & 0,6190 & 12,36 \\
\hline $\mathrm{Cr}$ & 5,0073 & 0 & 0 & 0 & 0,9861 & 0,1480 & 0,0015 & 0,0015 & 0,03 \\
\hline $\mathrm{Cu}$ & 5,0073 & 4,0140 & 0,5470 & 0,0220 & 0,9861 & 29,8880 & 0,2947 & 0,3167 & 6,32 \\
\hline $\mathrm{Fe}$ & 5,0073 & 4,0140 & 2,1220 & 0,0852 & 0,9861 & 23,0800 & 0,2276 & 0,3128 & 6,25 \\
\hline $\mathrm{Mn}$ & 5,0073 & 0 & 0 & 0 & 0,9861 & 0,6110 & 0,0060 & 0,0060 & 0,12 \\
\hline $\mathrm{Ni}$ & 5,0073 & 0 & 0 & 0 & 0,9861 & 1,1060 & 0,0109 & 0,0109 & 0,22 \\
\hline $\mathrm{Pb}$ & 5,0073 & 4,0140 & 0,4400 & 0,0177 & 0,9861 & 7,8240 & 0,0772 & 0,0948 & 1,89 \\
\hline$S$ & 5,0073 & 4,0140 & 0,7910 & 0,0318 & 0 & 0 & 0 & 0,0318 & 0,63 \\
\hline $\mathrm{Sb}$ & 5,0073 & 4,0140 & 0,4320 & 0,0173 & 0 & 0 & 0 & 0,0173 & 0,35 \\
\hline $\mathrm{Si}$ & 5,0073 & 4,0140 & 24,6700 & 0,9903 & 0,9861 & 1,6510 & 0,0163 & 1,0065 & 20,10 \\
\hline Sn & 5,0073 & 0 & 0 & 0 & 0,9861 & 8,3200 & 0,0820 & 0,0820 & 1,64 \\
\hline $\mathrm{Sr}$ & 5,0073 & 4,0140 & 0,2910 & 0,0117 & 0,9861 & 0,1640 & 0,0016 & 0,0133 & 0,27 \\
\hline $\mathrm{Zn}$ & 5,0073 & 4,0140 & 0,1240 & 0,0050 & 0,9861 & 2,4230 & 0,0239 & 0,0289 & 0,58 \\
\hline $\mathrm{Zr}$ & 5,0073 & 0 & 0 & 0 & 0,9861 & 0,6090 & 0,0060 & 0,0060 & 0,12 \\
\hline
\end{tabular}

Destacam-se pela concentração os elementos químicos Bromo, Cálcio, Silício, com uma participação representativa na amostra, respectiva de $41,77 \%, 12,36 \%$ e $20,10 \%$ em massa.

Pode-se notar ao comparar os elementos presentes nas duas amostras de sobrenadantes da granulometria 150 Mesh que a quantidade mássica porcentual é maior quando utilizado o bromoformio em relação ao clorofórmio, tais como $\mathrm{Br}, \mathrm{Ca}$, $\mathrm{Si}$, exceção apenas para $\mathrm{Cu}, \mathrm{Fe}$ e $\mathrm{Sb}$ que apresentaram uma redução da quantidade mássica porcentual.

Pode-se notar ao comparar os elementos decantados da granulometria 150 Mesh que a quantidade mássica porcentual é maior quando utilizado o bromoformio em relação ao clorofórmio, tais como $\mathrm{Ag}, \mathrm{Ba}, \mathrm{Cr}, \mathrm{Cu}, \mathrm{Fe}, \mathrm{Ni}, \mathrm{Pb}, \mathrm{Si}, \mathrm{Sn}, \mathrm{Sr}, \mathrm{Zn}, \mathrm{Zr}$, exceção apenas para $\mathrm{Al}, \mathrm{Br}, \mathrm{Ca}, \mathrm{Mn}, \mathrm{Nb}, \mathrm{S}, \mathrm{Sb} \mathrm{Ti}$, que apresentou uma redução da quantidade mássica porcentual. 
Tabela 4.15 - Elementos químicos presentes na amostra da granulometria Fundo (prato).

\begin{tabular}{|c|c|c|c|c|c|c|c|c|c|}
\hline $\begin{array}{l}\text { Elemento } \\
\text { quimico }\end{array}$ & $\begin{array}{l}\text { Material de } \\
\text { Partida } \\
\text { (g) }\end{array}$ & $\begin{array}{c}\text { Total do } \\
\text { Sobrenadante } \\
\text { (g) }\end{array}$ & $\begin{array}{c}\text { Sobrenadante } \\
(\%)\end{array}$ & $\begin{array}{l}\text { Quantidade do } \\
\text { Sobrenadante } \\
\text { (g) }\end{array}$ & $\begin{array}{c}\text { Total do } \\
\text { Decantado } \\
\text { (g) }\end{array}$ & $\begin{array}{c}\text { Decantado } \\
(\%)\end{array}$ & $\begin{array}{c}\text { Quantidade } \\
\text { do } \\
\text { Decantado } \\
\text { (g) }\end{array}$ & $\begin{array}{c}\begin{array}{c}\text { Somatória } \\
\text { das }\end{array} \\
\text { Quantidade } \\
\text { do } \\
\text { sobrenada } \\
\text { nte e do } \\
\text { decantado } \\
\text { (g) }\end{array}$ & $\begin{array}{c}\text { Elemento } \\
\text { quimico } \\
\text { Participação } \\
\text { Representativa } \\
(\%)\end{array}$ \\
\hline $\mathrm{Ag}$ & 5,0066 & 0 & 0 & 0 & 0,7988 & 0,4140 & 0,0033 & 0,0033 & 0,07 \\
\hline $\mathrm{Ba}$ & 5,0066 & 4,1515 & 1,4890 & 0,0618 & 0 & 0 & 0 & 0,0618 & 1,23 \\
\hline $\mathrm{Br}$ & 5,0066 & 4,1515 & 33,1840 & 1,3776 & 0,7988 & 16,8410 & 0,1345 & 1,5122 & 30,20 \\
\hline $\mathrm{Ca}$ & 5,0066 & 4,1515 & 28,3450 & 1,1767 & 0,7988 & 6,5410 & 0,0522 & 1,2290 & 24,55 \\
\hline $\mathrm{Cu}$ & 5,0066 & 4,1515 & 1,0250 & 0,0426 & 0,7988 & 13,2090 & 0,1055 & 0,1481 & 2,96 \\
\hline $\mathrm{Fe}$ & 5,0066 & 4,1515 & 4,6250 & 0,1920 & 0,7988 & 29,6730 & 0,2370 & 0,4290 & 8,57 \\
\hline $\mathrm{Mn}$ & 5,0066 & 0 & 0 & 0 & 0,7988 & 0,4560 & 0,0036 & 0,0036 & 0,07 \\
\hline $\mathrm{Ni}$ & 5,0066 & 4,1515 & 0,0500 & 0,0021 & 0,7988 & 0,7050 & 0,0056 & 0,0077 & 0,15 \\
\hline $\mathrm{Pb}$ & 5,0066 & 4,1515 & 0,6140 & 0,0255 & 0,7988 & 6,6400 & 0,0530 & 0,0785 & 1,57 \\
\hline$S$ & 5,0066 & 4,1515 & 0,3840 & 0,0159 & 0 & 0 & 0 & 0,0159 & 0,32 \\
\hline $\mathrm{Sb}$ & 5,0066 & 4,1515 & 0,3180 & 0,0132 & 0 & 0 & 0 & 0,0132 & 0,26 \\
\hline Si & 5,0066 & 4,1515 & 29,4500 & 1,2226 & 0,7988 & 9,4590 & 0,0756 & 1,2982 & 25,93 \\
\hline Sn & 5,0066 & 0 & 0 & 0 & 0,7988 & 12,9030 & 0,1031 & 0,1031 & 2,06 \\
\hline $\mathrm{Sr}$ & 5,0066 & 4,1515 & 0,3280 & 0,0136 & 0,7988 & 0,1000 & 0,0008 & 0,0144 & 0,29 \\
\hline $\mathrm{Zn}$ & 5,0066 & 4,1515 & 0,1870 & 0,0078 & 0,7988 & 2,8380 & 0,0227 & 0,0304 & 0,61 \\
\hline $\mathrm{Zr}$ & 5,0066 & 4,1515 & 0,0540 & 0,0022 & 0,7988 & 0,4980 & 0,0040 & 0,0062 & 0,12 \\
\hline
\end{tabular}

Dos elementos químicos da granulometria Fundo (prato), destacam-se pela concentração $\mathrm{Br}$, Ca e Si com uma participação representativa na amostra, respectiva de $30,20 \%, 24,55 \%$ e $25,93 \%$ em massa.

Pode-se notar ao comparar os elementos presentes nas duas amostras de sobrenadantes da granulometria Fundo (prato), que a quantidade mássica porcentual é maior quando utilizado o bromoformio em relação ao clorofórmio, tais como $\mathrm{Ca}, \mathrm{Ni}$, $\mathrm{Pb}, \mathrm{Sb}, \mathrm{Si}$, exceção apenas para $\mathrm{Ba}, \mathrm{Br}, \mathrm{Cu}, \mathrm{Fe}, \mathrm{S}, \mathrm{Sr}, \mathrm{Zn}$, que apresentaram uma redução da quantidade mássica porcentual.

Pode-se notar ao comparar os elementos decantados da granulometria Fundo (prato), que a quantidade mássica porcentual dos elementos é maior quando utilizado o bromoformio em relação ao clorofórmio, tais como $\mathrm{Ag}, \mathrm{Br}, \mathrm{Cu}, \mathrm{Fe}, \mathrm{Mn}, \mathrm{Ni}$, $\mathrm{Pb}, \mathrm{Sn}, \mathrm{Zn}, \mathrm{Zr}$, exceção apenas para $\mathrm{Ba}, \mathrm{Ca}, \mathrm{Mn}, \mathrm{S}, \mathrm{Sb} \mathrm{Si}, \mathrm{Sr}$, que apresentou uma redução da quantidade mássica porcentual. 


\subsubsection{Separação por densidade com solução de bromofórmio após remoagem.}

A Tabela 4.16 apresenta os resultados obtidos dos ensaios gravimétricos realizados para amostras de frações leves (não metálicos) com granulometrias 60,150 Mesh e Fundo (prato). Neste ensaio utilizou-se o líquido bromofórmio.

Tabela 4.16 - Resultados dos testes gravimétricos para as granulometrias 60, 150 Mesh e Fundo (prato).

\begin{tabular}{|c|c|c|c|c|}
\hline $\begin{array}{c}\text { Granulometria } \\
\text { em } \mathbf{M e s h}\end{array}$ & $\begin{array}{c}\text { Material de } \\
\text { Partida } \mathbf{( g )}\end{array}$ & $\begin{array}{c}\text { Fração } \\
\text { Leve } \mathbf{( g )}\end{array}$ & $\begin{array}{c}\text { Fração } \\
\text { Pesada (g) }\end{array}$ & $\begin{array}{c}\text { Perdas } \\
(\mathbf{g})\end{array}$ \\
\hline 60 & 2,0100 & 2,0022 & - & - \\
\hline 150 & 2,0388 & 2,0333 & - & - \\
\hline Fundo (prato) & 2,1513 & 2,0883 & - & - \\
\hline
\end{tabular}

Os resultados da composição química das placas de circuito impresso das frações leves (não metálicos) das granulometrias 60, 150 Mesh e Fundo (prato), foram submetidas à análise por fluorescência de Raios X, cujos resultados estão apresentados nas Tabelas 4.17, 4.18 e 4.19.

A Tabela 4.17 apresenta os resultados obtidos para a fração leve (não metálicos) do ensaio gravimétrico utilizando o líquido bromofórmio para a granulometria 60 Mesh.

Tabela 4.17 - Elementos químicos presentes na amostra da granulometria 60 Mesh.

\begin{tabular}{|c|c|c|c|c|c|}
\hline $\begin{array}{l}\text { Elemento } \\
\text { quimico }\end{array}$ & $\begin{array}{c}\text { Material de } \\
\text { Partida } \\
\text { posterior a } \\
\text { trituração } \\
\text { secundária } \\
\text { (g) } \\
\end{array}$ & $\begin{array}{c}\text { Total do } \\
\text { Sobrenadante } \\
\text { (g) }\end{array}$ & $\begin{array}{c}\text { Sobrenadante } \\
(\%)\end{array}$ & $\begin{array}{c}\text { Quantidade do } \\
\text { Sobrenadante } \\
\text { (g) }\end{array}$ & $\begin{array}{c}\text { Elemento } \\
\text { quimico } \\
\text { Participação } \\
\text { Representativa } \\
(\%)\end{array}$ \\
\hline $\mathrm{Ac}$ & 2,0100 & 2,0022 & 0,0650 & 0,0013 & 0,064748 \\
\hline $\mathrm{Ag}$ & 2,0100 & 2,0022 & O & O & 0 \\
\hline $\mathrm{Ba}$ & 2,0100 & 2,0022 & $\mathrm{O}$ & $\mathrm{O}$ & $\mathrm{O}$ \\
\hline $\mathrm{Br}$ & 2,0100 & 2,0022 & 36,1980 & 0,7248 & 36,057530 \\
\hline $\mathrm{Ca}$ & 2,0100 & 2,0022 & 6,2390 & 0,1249 & 6,214789 \\
\hline $\mathrm{Cr}$ & 2,0100 & 2,0022 & 0,1380 & 0,0028 & 0,137464 \\
\hline $\mathrm{Cu}$ & 2,0100 & 2,0022 & 0,2510 & 0,0050 & 0,250026 \\
\hline $\mathrm{Fe}$ & 2,0100 & 2,0022 & 3,0210 & 0,0605 & 3,009277 \\
\hline $\mathrm{K}$ & 2,0100 & 2,0022 & 0,4950 & 0,0099 & 0,493079 \\
\hline $\mathrm{Mg}$ & 2,0100 & 2,0022 & 1,2660 & 0,0253 & 1,261087 \\
\hline $\mathrm{Mn}$ & 2,0100 & 2,0022 & 0,1220 & 0,0024 & 0,121527 \\
\hline $\mathrm{Ni}$ & 2,0100 & 2,0022 & 0,0360 & 0,0007 & 0,035860 \\
\hline $\mathrm{P}$ & 2,0100 & 2,0022 & 0 & o & 0 \\
\hline $\mathrm{Pb}$ & 2,0100 & 2,0022 & 0,1250 & 0,0025 & 0,124515 \\
\hline$S$ & 2,0100 & 2,0022 & 0,8610 & 0,0172 & 0,857659 \\
\hline $\mathrm{Sb}$ & 2,0100 & 2,0022 & 1,0320 & 0,0207 & 1,027995 \\
\hline Se & 2,0100 & 2,0022 & 0,0720 & 0,0014 & 0,071721 \\
\hline Si & 2,0100 & 2,0022 & 48,2430 & 0,9659 & 48,055788 \\
\hline $\mathrm{Sr}$ & 2,0100 & 2,0022 & 0,0530 & 0,0011 & 0,052794 \\
\hline $\mathrm{Ti}$ & 2,0100 & 2,0022 & 1,5530 & 0,0311 & 1,546973 \\
\hline $\mathrm{Zn}$ & 2,0100 & 2,0022 & 0,2310 & 0,0046 & 0,230104 \\
\hline $\mathrm{Zr}$ & 2,0100 & 2,0022 & $\mathrm{O}$ & $\mathrm{O}$ & $\mathrm{O}$ \\
\hline
\end{tabular}


Ao analisar os resultados obtidos para a fração leve (não metálicos) do ensaio gravimétrico utilizando o líquido bromofórmio para a granulometria $60 \mathrm{Mesh}$, pode-se notar que :

Os elementos não metálicos presentes são o $\mathrm{Br}$, S e Se.

Os elementos de maior concentração são $\mathrm{Br}$ e $\mathrm{Si}$.

A Tabela 4.18 apresenta os resultados obtidos para a fração leve (não metálicos) do ensaio gravimétrico utilizando o líquido bromofórmio para a granulometria 150 Mesh.

Tabela 4.18 - Elementos químicos presentes na amostra da granulometria 150 Mesh.

\begin{tabular}{|c|c|c|c|c|c|}
\hline $\begin{array}{l}\text { Elemento } \\
\text { quimico }\end{array}$ & $\begin{array}{l}\text { Material de } \\
\text { Partida } \\
\text { posterior a } \\
\text { trituração } \\
\text { secundária } \\
\text { (g) }\end{array}$ & $\begin{array}{l}\text { Total do } \\
\text { Sobrenadante } \\
\text { (g) }\end{array}$ & $\begin{array}{c}\text { Sobrenadante } \\
(\%)\end{array}$ & $\begin{array}{c}\text { Quantidade do } \\
\text { Sobrenadante } \\
\text { (g) }\end{array}$ & $\begin{array}{c}\text { Elemento } \\
\text { quimico } \\
\text { Participação } \\
\text { Representativa } \\
(\%)\end{array}$ \\
\hline$A c$ & 2,0388 & 2,0333 & 0,1350 & 0,0027 & 0,134636 \\
\hline $\mathrm{Ba}$ & 2,0388 & 2,0333 & 0,9000 & 0,0183 & 0,897572 \\
\hline $\mathrm{Br}$ & 2,0388 & 2,0333 & 27,5030 & 0,5592 & 27,428806 \\
\hline $\mathrm{Ca}$ & 2,0388 & 2,0333 & 16,7260 & 0,3401 & 16,680879 \\
\hline $\mathrm{Cu}$ & 2,0388 & 2,0333 & 0,5570 & 0,0113 & 0,555497 \\
\hline $\mathrm{Fe}$ & 2,0388 & 2,0333 & 1,4570 & 0,0296 & 1,453070 \\
\hline $\mathrm{K}$ & 2,0388 & 2,0333 & 0,2440 & 0,0050 & 0,243342 \\
\hline $\mathrm{Mg}$ & 2,0388 & 2,0333 & 1,8100 & 0,0368 & 1,805117 \\
\hline $\mathrm{Ni}$ & 2,0388 & 2,0333 & 0,0290 & 0,0006 & 0,028922 \\
\hline$S$ & 2,0388 & 2,0333 & 0,6990 & 0,0142 & 0,697114 \\
\hline Si & 2,0388 & 2,0333 & 48,8890 & 0,9941 & 48,757114 \\
\hline $\mathrm{Sr}$ & 2,0388 & 2,0333 & 0,1470 & 0,0030 & 0,146603 \\
\hline $\mathrm{Ti}$ & 2,0388 & 2,0333 & 0,4150 & 0,0084 & 0,413880 \\
\hline $\mathrm{Zn}$ & 2,0388 & 2,0333 & 0,1000 & 0,0020 & 0,099730 \\
\hline $\mathrm{Zr}$ & 2,0388 & 2,0333 & 0,3900 & 0,0079 & 0,388948 \\
\hline
\end{tabular}

Ao analisar os resultados obtidos para a fração leve (não metálicos) do ensaio gravimétrico utilizando o líquido bromofórmio para a granulometria 150 Mesh, podese notar que :

Os elementos não metálicos presentes são o $\mathrm{Br}, \mathrm{S}$ e Se.

Os elementos de maior concentração são $\mathrm{Br}$ e Si. 
A Tabela 4.19 apresenta os resultados obtidos para a fração leve (não metálicos) do ensaio gravimétrico utilizando o líquido bromofórmio para a granulometria Fundo (prato).

Tabela 4.19 - Elementos químicos presentes na amostra da granulometria Fundo (prato).

\begin{tabular}{|c|c|c|c|c|c|}
\hline $\begin{array}{c}\text { Elemento } \\
\text { quimico }\end{array}$ & $\begin{array}{l}\text { Material de } \\
\text { Partida } \\
\text { posterior a } \\
\text { trituração } \\
\text { secundária } \\
\text { (g) }\end{array}$ & $\begin{array}{c}\text { Total do } \\
\text { Sobrenadante } \\
\text { (g) }\end{array}$ & $\begin{array}{c}\text { Sobrenadante } \\
(\%)\end{array}$ & $\begin{array}{c}\text { Quantidade do } \\
\text { Sobrenadante } \\
\text { (g) }\end{array}$ & $\begin{array}{c}\text { Elemento } \\
\text { quimico } \\
\text { Participação } \\
\text { Representativa } \\
(\%)\end{array}$ \\
\hline$A C$ & 2,1513 & 2,0883 & 0,0120 & 0,0003 & 0,011649 \\
\hline $\mathrm{Ba}$ & 2,1513 & 2,0883 & 1,2680 & 0,0265 & 1,230867 \\
\hline $\mathrm{Br}$ & 2,1513 & 2,0883 & 17,3350 & 0,3620 & 16,827351 \\
\hline $\mathrm{Ca}$ & 2,1513 & 2,0883 & 22,8620 & 0,4774 & 22,192495 \\
\hline $\mathrm{Cu}$ & 2,1513 & 2,0883 & 0,6810 & 0,0142 & 0,661057 \\
\hline $\mathrm{Fe}$ & 2,1513 & 2,0883 & 3,8420 & 0,0802 & 3,729488 \\
\hline K & 2,1513 & 2,0883 & 0,3080 & 0,0064 & 0,298980 \\
\hline $\mathrm{Ni}$ & 2,1513 & 2,0883 & 0,0440 & 0,0009 & 0,042711 \\
\hline$P$ & 2,1513 & 2,0883 & 2,5420 & 0,0531 & 2,467558 \\
\hline $\mathrm{Pb}$ & 2,1513 & 2,0883 & 0,2550 & 0,0053 & 0,247532 \\
\hline S & 2,1513 & 2,0883 & 0,3450 & 0,0072 & 0,334897 \\
\hline $\mathrm{Sb}$ & 2,1513 & 2,0883 & 0,1120 & 0,0023 & 0,108720 \\
\hline $\mathrm{Si}$ & 2,1513 & 2,0883 & 46,2770 & 0,9664 & 44,921796 \\
\hline $\mathrm{Sr}$ & 2,1513 & 2,0883 & 0,1680 & 0,0035 & 0,163080 \\
\hline $\mathrm{Ti}$ & 2,1513 & 2,0883 & 0,3880 & 0,0081 & 0,376638 \\
\hline $\mathrm{Zn}$ & 2,1513 & 2,0883 & 0,1350 & 0,0028 & 0,131047 \\
\hline $\mathrm{Zr}$ & 2,1513 & 2,0883 & 3,4270 & 0,0716 & 3,326642 \\
\hline
\end{tabular}

Ao analisar os resultados obtidos para a fração leve (não metálicos) do ensaio gravimétrico utilizando o líquido bromofórmio para a granulometria Fundo (prato), pode-se notar que :

Os elementos não metálicos presentes são o $\mathrm{Br}, \mathrm{P}$ e S.

Os elementos de maior concentração são $\mathrm{Br}$, $\mathrm{Ca}$ e $\mathrm{Si}$. 
Ao analisar os elementos químicos presentes no sobrenadantes, nas 3 amostras de granulometria 60,150 e Fundo (prato), foi possível identificar que:

Quanto menor a granulometria, observa-se também que ocorre redução da presença tanto do Bromo como do Enxofre.

Notou-se a presença do Fósforo, apenas, na granulometria Fundo (prato).

Notou-se a presença do Selênio, apenas, na granulometria 60 Mesh.

Realizou-se o estudo comparativo dos resultados obtidos utilizando a solução de bromofórmio do primeiro ensaio com, os resultados obtidos no segundo ensaio.

Para tal foram utilizadas apenas as frações (leve) de ambos os ensaios, das três granulometria 60, 150 Mesh e Fundo (prato).

Esta etapa de remoagem foi realizada para verificar a efetividade no processo de separação dos elementos metálicos, presentes na fração leve (sobrenadante) das amostras de 60, 150 Mesh e Fundo (prato).

A tabela 4.21 mostra o resultado da comparação química em termos mássicos dos dois ensaios experimentais (moagem e remoagem) para a granulometria 60 Mesh.

Tabela - 4.20 Elementos químicos presentes nas amostras da granulometria 60 Mesh.

\begin{tabular}{|c|c|c|c|c|c|c|}
\hline $\begin{array}{l}\text { Elemento } \\
\text { quimico }\end{array}$ & $\begin{array}{c}1^{\circ} \text { Ensaio Total } \\
\text { do } \\
\begin{array}{c}\text { Sobrenadante } \\
\text { (g) }\end{array} \\
\end{array}$ & \begin{tabular}{|c}
$1^{\circ}$ Ensaio Total \\
do \\
$\begin{array}{c}\text { Sobrenadante } \\
(\%)\end{array}$ \\
\end{tabular} & $\begin{array}{c}1^{\circ} \text { Ensaio } \\
\text { Quantidade do } \\
\text { Sobrenadante } \\
\text { (g) }\end{array}$ & $\begin{array}{c}2^{\circ} \text { Ensaio } \\
\text { Total do } \\
\text { Sobrenadante } \\
(\mathrm{g})\end{array}$ & $\begin{array}{c}2^{\circ} \text { Ensaio } \\
\text { Total do } \\
\text { Sobrenadante } \\
(\%)\end{array}$ & $\begin{array}{c}2^{\circ} \text { Ensaio } \\
\text { Quantidade do } \\
\text { Sobrenadante } \\
\text { (g) }\end{array}$ \\
\hline$A c$ & 0 & 0 & 0 & 2,0222 & 0,0650 & 0,0013 \\
\hline $\mathrm{Al}$ & 2,3812 & 20,3440 & 0,4844 & 0 & 0 & 0 \\
\hline $\mathrm{Ag}$ & 0 & 0 & 0 & 0 & 0 & 0 \\
\hline $\mathrm{Ba}$ & 2,3812 & 2,5560 & 0,0609 & 0 & 0 & 0 \\
\hline $\mathrm{Br}$ & 2,3812 & 48,7680 & 1,1613 & 2,0222 & 36,1980 & 0,7320 \\
\hline $\mathrm{Ca}$ & 2,3812 & 13,6330 & 0,3246 & 2,0222 & 6,2390 & 0,1262 \\
\hline $\mathrm{Cr}$ & 0 & 0 & 0 & 2,0222 & 0,1380 & 0,0028 \\
\hline $\mathrm{Cu}$ & 2,3812 & 0,6430 & 0,0153 & 2,0222 & 0,2510 & 0,0051 \\
\hline $\mathrm{Fe}$ & 2,3812 & 6,6340 & 0,1580 & 2,0222 & 3,0210 & 0,0611 \\
\hline $\mathrm{K}$ & 0 & 0 & 0 & 2,0222 & 0,4950 & 0,0100 \\
\hline $\mathrm{Mg}$ & 0 & 0 & 0 & 2,0222 & 1,2660 & 0,0256 \\
\hline $\mathrm{Mn}$ & 2,3812 & 0,2160 & 0,0051 & 2,0222 & 0,1220 & 0,0025 \\
\hline $\mathrm{Ni}$ & 0 & 0 & 0 & 2,0222 & 0,0360 & 0,0007 \\
\hline $\mathrm{P}$ & 0 & 0 & 0 & 0 & 0 & 0 \\
\hline $\mathrm{Pb}$ & 2,3812 & 0,7320 & 0,0174 & 2,0222 & 0,1250 & 0,0025 \\
\hline $\mathrm{S}$ & 2,3812 & 0,5540 & 0,0132 & 2,0222 & 0,8610 & 0,0174 \\
\hline $\mathrm{Sb}$ & 2,3812 & 4,7820 & 0,1139 & 2,0222 & 1,0320 & 0,0209 \\
\hline $\mathrm{Se}$ & 0 & 0 & 0 & 2,0222 & 0,0720 & 0,0015 \\
\hline Si & 2,3812 & 19,2040 & 0,4573 & 2,0222 & 48,2430 & 0,9756 \\
\hline Sn & 0 & 0 & 0 & 0 & 0 & 0 \\
\hline $\mathrm{Sr}$ & 2,3812 & 0,2420 & 0,0058 & 2,0222 & 0,0530 & 0,0011 \\
\hline $\mathrm{Ti}$ & 2,3812 & 3,9650 & 0,0944 & 2,0222 & 1,5530 & 0,0314 \\
\hline $\mathrm{Zn}$ & 2,3812 & 0,4510 & 0,0107 & 2,0222 & 0,2310 & 0,0047 \\
\hline $\mathrm{Zr}$ & 2,3812 & 0,1750 & 0,0042 & 0 & 0 & 0 \\
\hline
\end{tabular}


Entre os elementos químicos não metálicos, presentes nestas amostras, estão $\mathrm{Br}, \mathrm{S}$, Se.

O elemento químico $\mathrm{Br}$ no segundo ensaio apresentou uma redução aproximada de $12 \%$ em massa, sendo a causa provável evaporação ou dissolução na solução de moagem.

O elemento químico $S$ no segundo ensaio apresentou um aumento aproximado de $0,5 \%$ em massa, podendo ser resultado de uma desagregação.

O elemento químico Se, que não acusou presença no primeiro ensaio, agora se faz presente no segundo ensaio, podendo ser resultado de uma desagregação.

Quanto aos elementos químicos metálicos, que estavam presentes no primeiro ensaio e ausentes no segundo ensaio, são $\mathrm{Al}, \mathrm{Ba}, \mathrm{Zr}$, tendo ocorrido uma separação efetiva na remoagem.

Não houve ocorrência de elementos químicos metálicos, que estavam presentes no primeiro ensaio e apresentaram um aumento quantidade mássica no segundo ensaio.

Quanto aos elementos químicos metálicos, que estavam presentes no primeiro ensaio e apresentaram redução da quantidade mássica no segundo ensaio, são $\mathrm{Ca}, \mathrm{Cu}, \mathrm{Fe}, \mathrm{Mn}, \mathrm{Pb}, \mathrm{Sr}, \mathrm{Ti}$ e $\mathrm{Zn}$, comprova que a remoagem foi efetiva proporcionando maior separação por processo gravimétrico.

Quanto aos elementos químicos metálicos, que estavam ausentes no primeiro ensaio e que, tornaram-se presentes no segundo ensaio são $\mathrm{Cr}, \mathrm{K}, \mathrm{Mg}, \mathrm{Ni}$, tal ocorrência pode ser em função da separação. 
A tabela 4.21 mostra o resultado da comparação química em termos mássicos dos dois ensaios experimentais (moagem e remoagem) para a granulometria 150 Mesh.

Tabela - 4.21 Elementos químicos presentes nas amostras da granulometria 150 Mesh.

\begin{tabular}{|c|c|c|c|c|c|c|}
\hline $\begin{array}{l}\text { Elemento } \\
\text { quimico }\end{array}$ & \begin{tabular}{|c}
$1^{\circ}$ Ensaio Total \\
do \\
Sobrenadante \\
(g)
\end{tabular} & $\begin{array}{c}1^{\circ} \text { Ensaio Total } \\
\text { do } \\
\text { Sobrenadante } \\
(\%)\end{array}$ & $\begin{array}{c}1^{\circ} \text { Ensaio } \\
\begin{array}{c}\text { Quantidade do } \\
\text { Sobrenadante } \\
\text { (g) }\end{array} \\
\end{array}$ & $\begin{array}{c}2^{\circ} \text { Ensaio } \\
\text { Total do } \\
\text { Sobrenadante } \\
\text { (g) }\end{array}$ & $\begin{array}{c}2^{\circ} \text { Ensaio } \\
\text { Total do } \\
\text { Sobrenadante } \\
(\%)\end{array}$ & $\begin{array}{c}2^{\circ} \text { Ensaio } \\
\text { Quantidade do } \\
\text { Sobrenadante } \\
\text { (g) }\end{array}$ \\
\hline$A C$ & 0 & 0 & 0 & 2,0333 & 0,1350 & 0,0027 \\
\hline $\mathrm{Ag}$ & 0 & 0 & 0 & 0 & 0 & 0 \\
\hline $\mathrm{Al}$ & 0 & 0 & 0 & 0 & 0 & 0 \\
\hline $\mathrm{Ba}$ & 4,0140 & 3,9060 & 0,1568 & 2,0333 & 0,9000 & 0,0183 \\
\hline $\mathrm{Br}$ & 4,0140 & 51,2550 & 2,0574 & 2,0333 & 27,5030 & 0,5592 \\
\hline $\mathrm{Ca}$ & 4,0140 & 15,4220 & 0,6190 & 2,0333 & 16,7260 & 0,3401 \\
\hline $\mathrm{Cr}$ & 0 & 0 & 0 & 0 & 0 & 0 \\
\hline $\mathrm{Cu}$ & 4,0140 & 0,5470 & 0,0220 & 2,0333 & 0,5570 & 0,0113 \\
\hline $\mathrm{Fe}$ & 4,0140 & 2,1220 & 0,0852 & 2,0333 & 1,4570 & 0,0296 \\
\hline $\mathrm{K}$ & 0 & 0 & 0 & 2,0333 & 0,2440 & 0,0050 \\
\hline $\mathrm{Mg}$ & 0 & 0 & 0 & 2,0333 & 1,8100 & 0,0368 \\
\hline $\mathrm{Mn}$ & 0 & 0 & 0 & 0 & 0 & 0 \\
\hline $\mathrm{Ni}$ & 0 & 0 & 0 & 2,0333 & 0,0290 & 0,0006 \\
\hline $\mathrm{Pb}$ & 4,0140 & 0,4400 & 0,0177 & 0 & 0 & 0 \\
\hline $\mathrm{S}$ & 4,0140 & 0,7910 & 0,0318 & 2,0333 & 0,6990 & 0,0142 \\
\hline $\mathrm{Sb}$ & 4,0140 & 0,4320 & 0,0173 & 0 & 0 & 0 \\
\hline $\mathrm{Si}$ & 4,0140 & 24,6700 & 0,9903 & 2,0333 & 48,8890 & 0,9941 \\
\hline Sn & 0 & 0 & 0 & 0 & 0 & 0 \\
\hline $\mathrm{Sr}$ & 4,0140 & 0,2910 & 0,0117 & 2,0333 & 0,1470 & 0,0030 \\
\hline $\mathrm{Ti}$ & 0 & 0 & 0 & 2,0333 & 0,4150 & 0,0084 \\
\hline $\mathrm{Zn}$ & 4,0140 & 0,1240 & 0,0050 & 2,0333 & 0,1000 & 0,0020 \\
\hline $\mathrm{Zr}$ & 0 & 0 & 0 & 2,0333 & 0,3900 & 0,0079 \\
\hline
\end{tabular}

Entre os elementos químicos não metálicos, presentes nestas amostras, estão Bromo, Enxofre.

O elemento químico $\mathrm{Br}$ no segundo ensaio apresentou uma redução aproximada de $24 \%$ em massa, sendo a causa provável evaporação ou dissolução na solução de moagem.

O elemento químico $S$ no segundo ensaio apresentou aumento aproximado de $1 \%$ em massa, podendo ser resultado de uma separação. 
Quanto aos elementos químicos metálicos, que estavam presentes no primeiro ensaio e ausentes no segundo ensaio, são $\mathrm{Pb}$, e $\mathrm{Sb}$, tendo ocorrido uma provável desagregação.

Os elementos químicos metálicos, que estavam presentes no primeiro ensaio e apresentou aumento da quantidade mássica no segundo ensaio, apenas o Cu.

Quanto aos elementos químicos metálicos, que estavam presentes no primeiro ensaio e apresentaram redução de presença no segundo ensaio, são o Ba, Sr e Zn, comprova que a remoagem foi efetiva proporcionando maior desagregação.

Quanto aos elementos químicos metálicos, que estavam ausentes no primeiro ensaio e que, tornaram-se presentes no segundo ensaio são $\mathrm{K}, \mathrm{Mg}, \mathrm{Ni}, \mathrm{Ti}, \mathrm{Zr}$, tal ocorrência pode ser em função da desagregação pela remoagem.

A tabela 4.22 mostra o resultado da comparação química em termos mássicos dos dois ensaios experimentais (moagem e remoagem) para a granulometria Fundo (prato).

Tabela - 4.22 Elementos químicos presentes nas amostras da granulometria Fundo (prato).

\begin{tabular}{|c|c|c|c|c|c|c|}
\hline $\begin{array}{l}\text { Elemento } \\
\text { quimico }\end{array}$ & $\begin{array}{c}1^{\circ} \text { Ensaio Total } \\
\text { do } \\
\text { Sobrenadante } \\
\text { (g) }\end{array}$ & $\begin{array}{c}1^{\circ} \text { Ensaio Total } \\
\text { do } \\
\text { Sobrenadante } \\
(\%)\end{array}$ & $\begin{array}{c}1^{\circ} \text { Ensaio } \\
\text { Quantidade do } \\
\text { Sobrenadante } \\
\text { (g) }\end{array}$ & $\begin{array}{c}2^{\circ} \text { Ensaio } \\
\text { Total do } \\
\text { Sobrenadante } \\
\text { (g) }\end{array}$ & $\begin{array}{c}2^{\circ} \text { Ensaio } \\
\text { Total do } \\
\text { Sobrenadante } \\
(\%)\end{array}$ & $\begin{array}{c}2^{\circ} \text { Ensaio } \\
\text { Quantidade do } \\
\text { Sobrenadante } \\
\text { (g) }\end{array}$ \\
\hline$A C$ & 0 & 0 & 0 & 2,0883 & 0,0120 & 0,0003 \\
\hline $\mathrm{Ag}$ & 0 & 0 & 0 & 0 & 0 & 0 \\
\hline $\mathrm{Ba}$ & 4,1515 & 1,4890 & 0,0618 & 2,0883 & 1,2680 & 0,0265 \\
\hline $\mathrm{Br}$ & 4,1515 & 33,1840 & 1,3776 & 2,0883 & 17,3350 & 0,3620 \\
\hline $\mathrm{Ca}$ & 4,1515 & 28,3450 & 1,1767 & 2,0883 & 22,8620 & 0,4774 \\
\hline $\mathrm{Cu}$ & 4,1515 & 1,0250 & 0,0426 & 2,0883 & 0,6810 & 0,0142 \\
\hline $\mathrm{Fe}$ & 4,1515 & 4,6250 & 0,1920 & 2,0883 & 3,8420 & 0,0802 \\
\hline K & 0 & 0 & 0 & 2,0883 & 0,3080 & 0,0064 \\
\hline $\mathrm{Mn}$ & 0 & 0 & 0 & 0 & 0 & 0 \\
\hline $\mathrm{Ni}$ & 4,1515 & 0,0500 & 0,0021 & 2,0883 & 0,0440 & 0,0009 \\
\hline $\mathrm{P}$ & 0 & 0 & 0 & 2,0883 & 2,5420 & 0,0531 \\
\hline $\mathrm{Pb}$ & 4,1515 & 0,6140 & 0,0255 & 2,0883 & 0,2550 & 0,0053 \\
\hline $\mathrm{S}$ & 4,1515 & 0,3840 & 0,0159 & 2,0883 & 0,3450 & 0,0072 \\
\hline $\mathrm{Sb}$ & 4,1515 & 0,3180 & 0,0132 & 2,0883 & 0,1120 & 0,0023 \\
\hline $\mathrm{Si}$ & 4,1515 & 29,4500 & 1,2226 & 2,0883 & 46,2770 & 0,9664 \\
\hline Sn & 0 & 0 & 0 & 0 & 0 & 0 \\
\hline $\mathrm{Sr}$ & 4,1515 & 0,3280 & 0,0136 & 2,0883 & 0,1680 & 0,0035 \\
\hline $\mathrm{Ti}$ & 0 & 0 & 0 & 2,0883 & 0,3880 & 0,0081 \\
\hline $\mathrm{Zn}$ & 4,1515 & 0,1870 & 0,0078 & 2,0883 & 0,1350 & 0,0028 \\
\hline $\mathrm{Zr}$ & 4,1515 & 0,0540 & 0,0022 & 2,0883 & 3,4270 & 0,0716 \\
\hline
\end{tabular}


Entre os elementos químicos não metálicos, presentes nestas amostras, estão $\mathrm{Br}, \mathrm{P}$ e S.

O elemento químico $\mathrm{Br}$ no segundo ensaio apresentou uma redução aproximada de $16 \%$ em massa , sendo a causa provável evaporação ou dissolução na solução de moagem.

O elemento químico $S$ no segundo ensaio apresentou uma aumento aproximado de $1 \%$ em massa, podendo ser resultado de uma desagregação.

Os elementos químicos $\mathrm{Ac}, \mathrm{K}, \mathrm{P}, \mathrm{Ti}$, que não acusaram presença no primeiro ensaio, agora se fazem presentes no segundo ensaio, podendo ser resultado de uma desagregação.

Quanto ao elemento químico, $\mathrm{Ti}$, metais, presente no primeiro ensaio e ausente no segundo ensaio, tal fato pode ser decorrente de uma provável desagregação.

Houve apenas uma ocorrência para o elemento químico, Zr, s, que estava presente no primeiro ensaio e apresentou um aumento da quantidade mássica no segundo ensaio.

Quanto aos elementos químicos metálicos, que estavam presentes no primeiro ensaio e apresentaram redução de presença no segundo ensaio, são $\mathrm{Ba}$, $\mathrm{Ca}, \mathrm{Cu}, \mathrm{Fe}, \mathrm{Ni}, \mathrm{Pb}, \mathrm{S}, \mathrm{Sb}, \mathrm{Sr}$ e $\mathrm{Zn}$, comprova que a remoagem foi efetiva proporcionando maior desagregação.

Quanto aos elementos químicos metálicos, que estavam ausentes no primeiro ensaio e que, tornaram-se presentes no segundo ensaio são $\mathrm{K}, \mathrm{P}, \mathrm{Ti}$, tal ocorrência pode ser em função da desagregação pela remoagem.

Ao comparar os resultados obtidos nos ensaios primeiro e segundo, para as três faixas granulométricas, observa-se que para alguns elementos químicos uma variação bastante acentuada, seja na redução ou no aumento a da quantidade mássica, desta forma pode-se afirmar que a remoagem se mostrou efetiva ao melhorar o processo de separação do material, houve um melhor rendimento no processo de separação aumentando a eficácia da separação. 


\subsection{Caracterização de polímeros por meio da Espectrometria de Infravermelho}

Neste ensaio, fez-se estudo para caracterizar os polímeros presentes na amostra, de placas de circuito impresso, referente à fração leve (não metálicos) das granulometrias 60, 150 Mesh e Fundo (prato), por meio da utilização da espectrometria de infravermelho.

Para caracterizar a presença de polímeros nesta amostra, recorreu-se a análise de FT-IR que fornece evidências sobre a presença de vários grupos orgânicos e inorgânicos, de acordo com a análise dos picos de absorção gerados pelas energias de vibração das respectivas moléculas/grupos presentes na amostra, para tal utilizou-se um esquema de orientação conforme Figura 4.3.

Neste ensaio os resultados obtidos são apresentados, para a granulometria 60 Mesh, por meio do gráfico (figura 4.4) e da tabela 4.23, para a granulometria 150 Mesh, por meio do gráfico (figura 4.5) e da tabela 4.24 e para a granulometria Fundo (prato), por meio do gráfico (figura 4.6) e da tabela 4.25 e para a resina epóxi, por meio do gráfico (figura 4.7) e da tabela 4.26.

O gráfico (figura 4.8) apresenta a comparação dos espectros da resina epóxi e da granulometria 60 Mesh.

O gráfico (figura 4.9) apresenta a comparação dos espectros da resina epóxi e da granulometria 150 mesh.

O gráfico (figura 4.10) apresenta a comparação dos espectros da resina epóxi e da granulometria Fundo (prato).

As amostras foram analisadas em número de ondas na faixa de leitura de 4000 a $400 \mathrm{~cm}^{-1}$.

Para analise e interpretação dos espectros de FT-IR utilizou-se os valores apresentados no esquema da figura 4.3. 


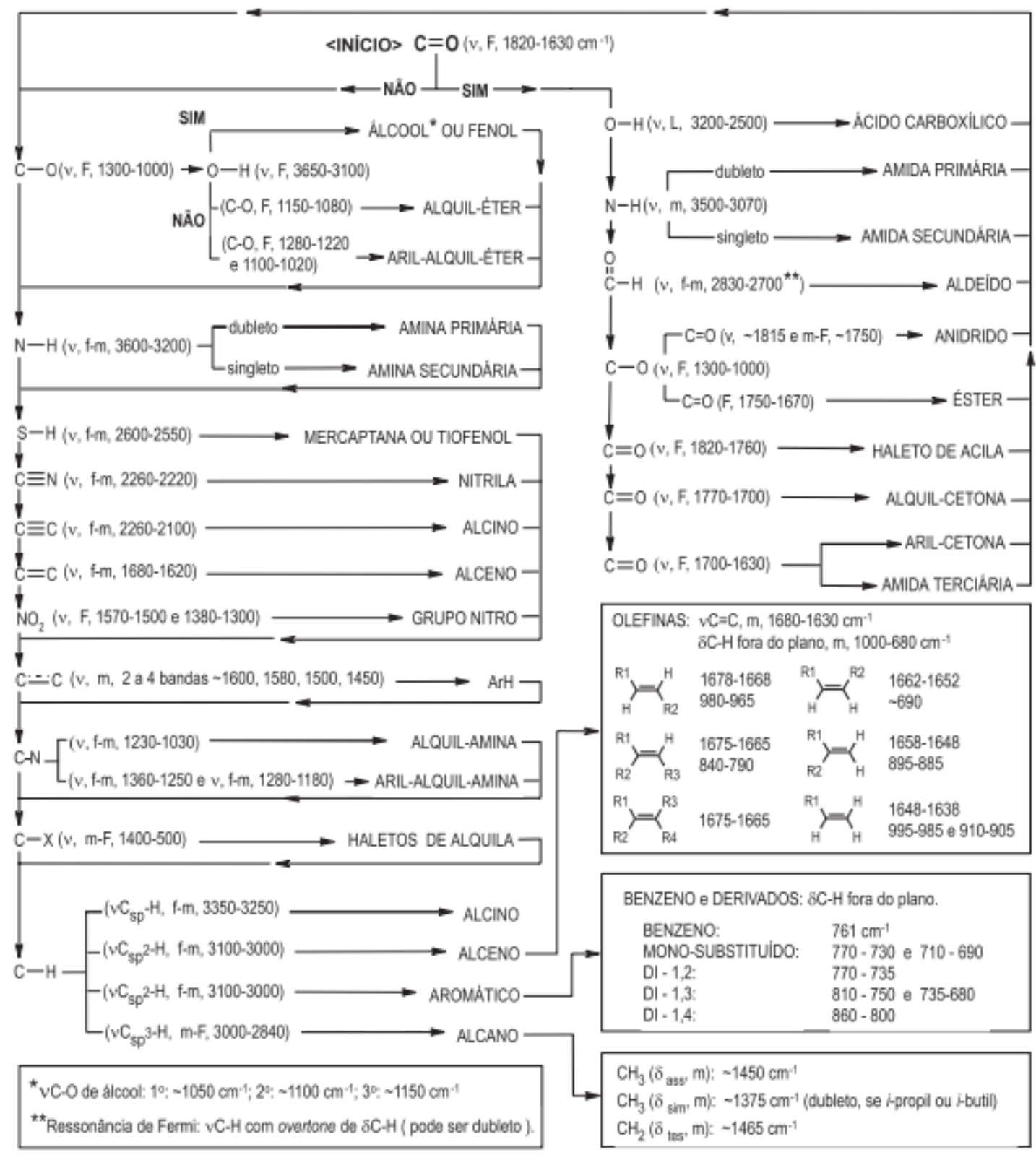

$\mathrm{v}=$ estiramento; $\delta=$ deformaçäo; ass = assimétrica; sim = simétriaca; tes = tesoura; $\mathrm{F}=$ forte; $\mathrm{m}=$ media; $\mathrm{f}=$ fraca; $\mathrm{L}=$ larga; $\mathrm{v}=\mathrm{variavel}$.

Figura 4.3 - Esquema para interpretação de espectros de substâncias orgânicas na região do infravermelho.(LOPES,2003).

O material sobrenadante, fração leve (não metálico) da granulométrica 60 Mesh, foi submetido a análise por Infravermelho e o resultado obtido neste ensaio é apresentado pelo espectro FT-IR na Figura 4.4. 


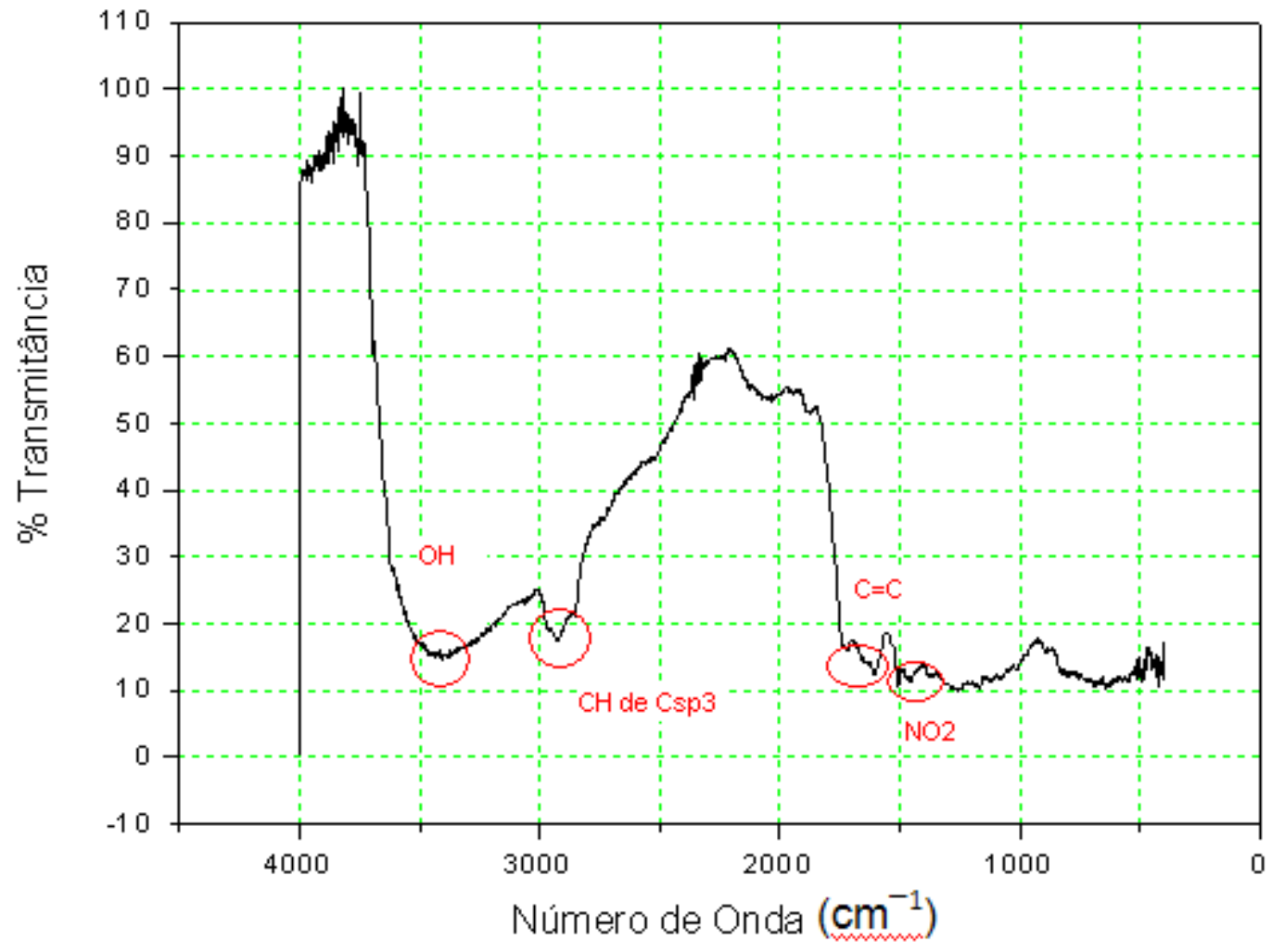

Figura 4.4 - Espectro de FT-IR do material sobrenadante para a granulometria 60 Mesh.

No espectro do material, amostra extraída do sobrenadante da granulometria 60 Mesh, é possível identificar a banda característica atribuída às vibrações de estiramento das ligações $\mathrm{O}-\mathrm{H}$.

A banda referente às vibrações de estiramento das ligações $\mathrm{O}-\mathrm{H}$ aparece, normalmente, entre os 3650 e os $33100 \mathrm{~cm}^{-1}$ conforme Figura 4.4 .

$\mathrm{Na}$ banda identificada neste espectro encontra-se por volta dos $3409 \mathrm{~cm}^{-1}$, o que indica que estes grupos fazem parte de uma ligação de hidrogênio, encontrandose desviada para comprimentos de onda menores.

$\mathrm{Na}$ banda $2917 \mathrm{~cm}^{-1}$, identificam-se características das vibrações de estiramento das ligações $\mathrm{C}-\mathrm{H}$ alifáticas. 
$\mathrm{Na}$ banda $1606 \mathrm{~cm}^{-1}$, identificam-se características das vibrações de estiramento das ligações $\mathrm{C}=\mathrm{C}$, grupo aromáticos.

$\mathrm{Na}$ banda $1510 \mathrm{~cm}^{-1}$, identificam-se características das vibrações de estiramento das ligações $\mathrm{NO}_{2}$, grupo nitro.

São apresentadas as principais bandas de absorção da luz infravermelha dos comprimentos de onda, no espectro do sobrenadante 60 mesh, por meio da tabela 4.23.

Tabela 4.23 - Bandas referenciadas na granulometria 60 mesh.

\begin{tabular}{cc}
\hline Banda $\left(\mathbf{c m}^{-\mathbf{1}}\right)$ & Atribuição \\
\hline 3409 & Estiramento da ligação O-H \\
2917 & Estiramento da ligação C-H \\
1606 & Estiramento da ligação C=C \\
1510 & Estiramento da ligação $\mathrm{NO}_{2}$ \\
\hline
\end{tabular}

O material sobrenadante, fração leve (não metálico) da granulometria 150 Mesh, foi submetido a análise por Infravermelho e o resultado obtido neste ensaio é apresentado pelo espectro FT-IR na Figura 4.5. 


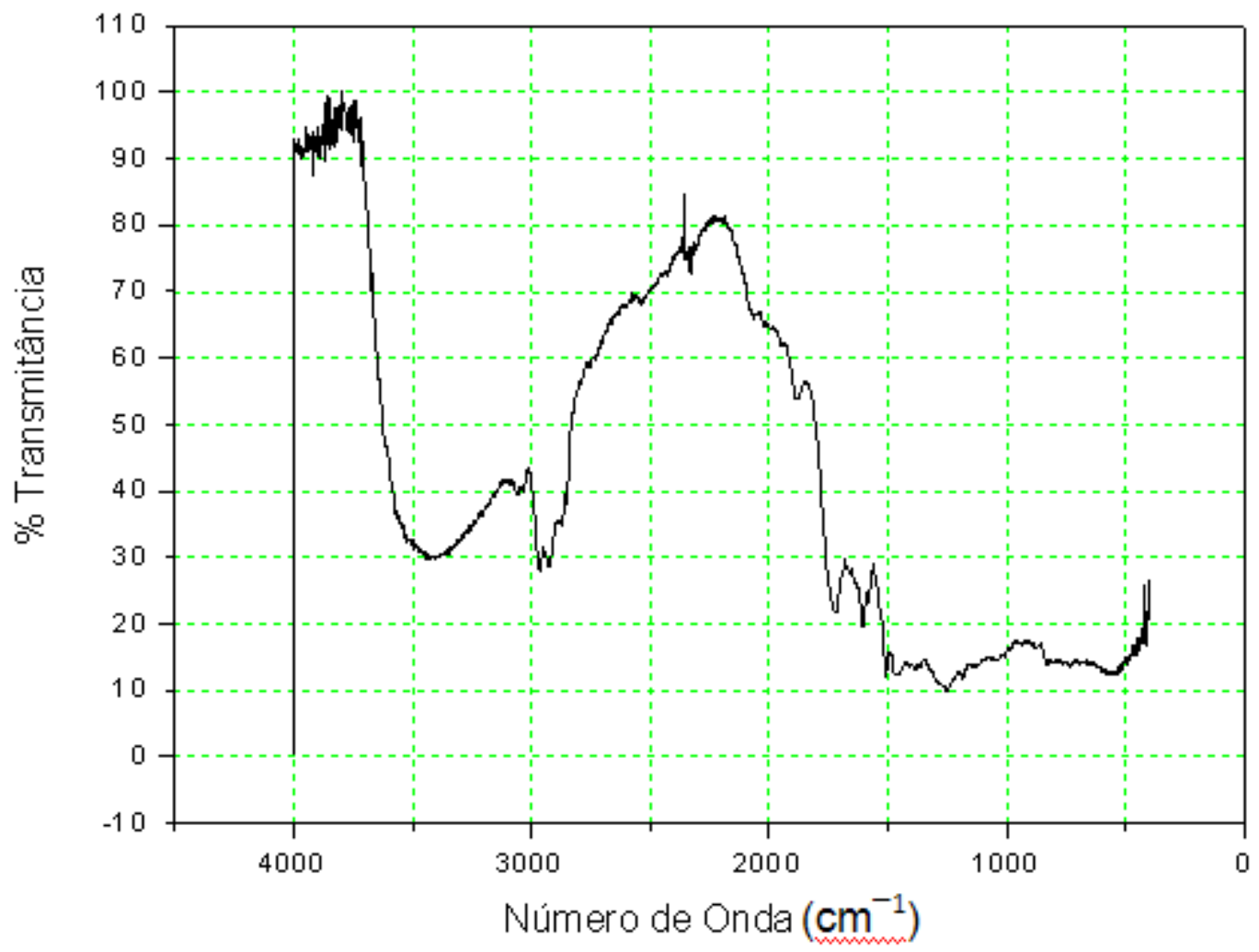

Figura 4.5 - Espectro de FT-IR do material sobrenadante para a granulometria 150 Mesh.

$\mathrm{Na}$ banda $3399 \mathrm{~cm}^{-1}$, identificam-se características das vibrações de estiramento das ligações $\mathrm{O}-\mathrm{H}$, grupo hidroxilas.

$\mathrm{Na}$ banda $2966 \mathrm{~cm}^{-1}$, identificam-se características das vibrações de estiramento das ligações Csp3, grupo alcinos.

$\mathrm{Na}$ banda $2929 \mathrm{~cm}^{-1}$, identificam-se características das vibrações de estiramento das ligações Csp3, grupo alcinos.

$\mathrm{Na}$ banda $2171 \mathrm{~cm}^{-1}$, identificam-se características das vibrações de estiramento das ligações $C_{-}=C$, grupo carboxila.

$\mathrm{Na}$ banda $1608 \mathrm{~cm}^{-1}$, identificam-se características das vibrações de estiramento das ligações C-C, grupo alcanos. 
$\mathrm{Na}$ banda $1255 \mathrm{~cm}^{-1}$, identificam-se características das vibrações de estiramento das ligações C-O, grupo ésteres.

São apresentadas as principais bandas de absorção da luz infravermelha dos comprimentos de onda, no espectro do sobrenadante 150 Mesh, por meio da tabela 4.24 .

Tabela 4.24 - Bandas referenciadas na granulometria 150 mesh.

\begin{tabular}{cc}
\hline Banda $\left(\mathbf{c m}^{-\mathbf{1}}\right)$ & Atribuição \\
\hline 3399 & Estiramento da ligação O-H \\
2966 & Estiramento da ligação Csp3 \\
2929 & Estiramento da ligação Csp3 \\
2171 & Estiramento da ligação C_=C \\
1608 & Estiramento da ligação C=C \\
1255 & Estiramento da ligação C-O \\
\hline
\end{tabular}

O material sobrenadante, fração leve (não metálico) da granulometria granulométrica Fundo (prato), foi submetido a análise por Infravermelho e o resultado obtido neste ensaio é apresentado pelo espectro FT-IR na Figura 4.6. 


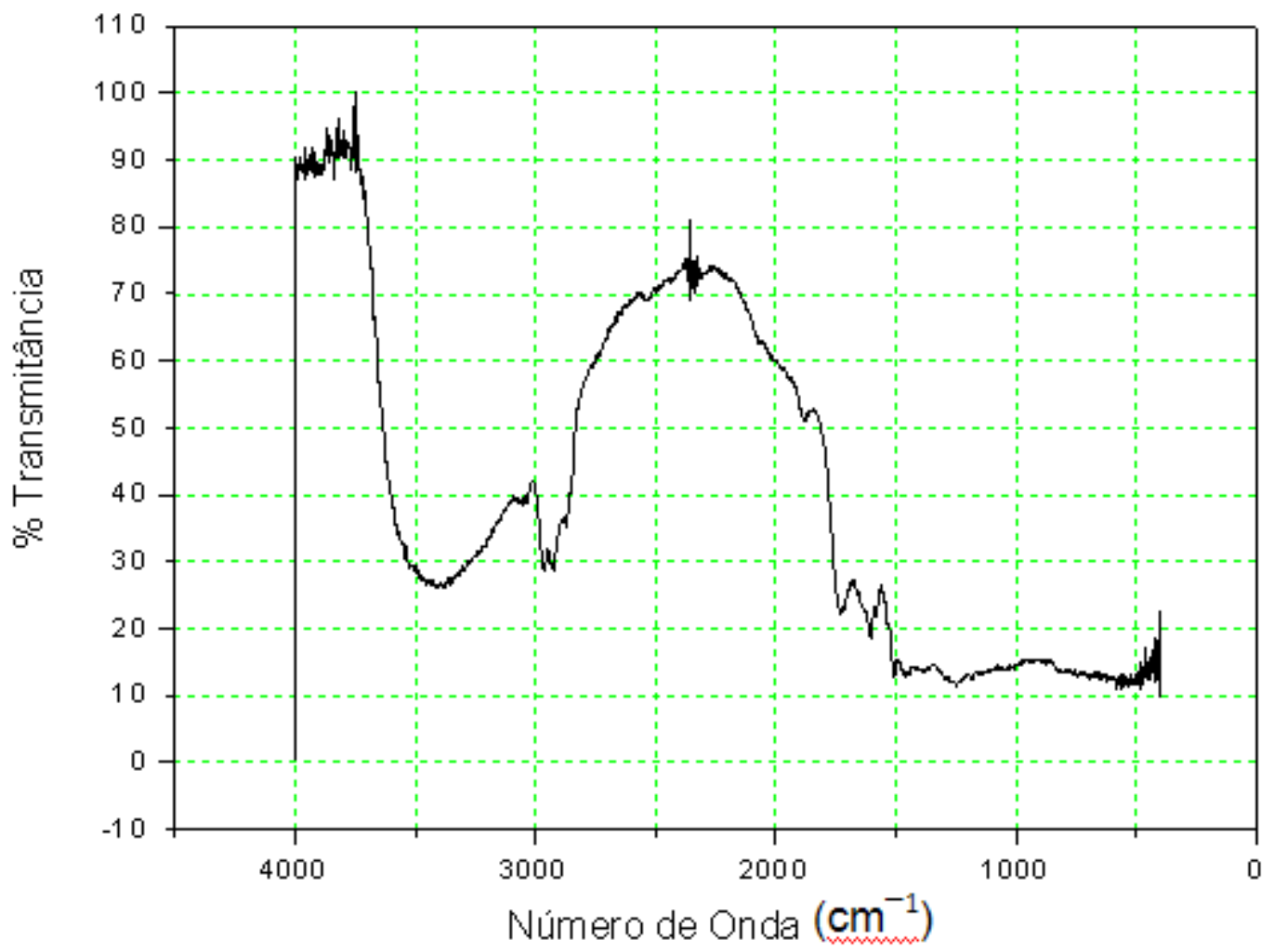

Figura 4.6 - Espectro de FT-IR do material sobrenadante para a granulometria Fundo (prato).

$\mathrm{Na}$ banda $3417 \mathrm{~cm}^{-1}$, identificam-se características das vibrações de estiramento das ligações $\mathrm{O}-\mathrm{H}$, grupo hidroxilas.

$\mathrm{Na}$ banda $2929 \mathrm{~cm}^{-1}$, identificam-se características das vibrações de estiramento das ligações Csp3, grupo alcinos.

$\mathrm{Na}$ banda $1727 \mathrm{~cm}^{-1}$, identificam-se características das vibrações de estiramento das ligações $\mathrm{C}=\mathrm{O}$, grupo ésteres.

$\mathrm{Na}$ banda $1606 \mathrm{~cm}^{-1}$, identificam-se características das vibrações de estiramento das ligações $\mathrm{C}=\mathrm{C}$, grupo aromáticos.

$\mathrm{Na}$ banda $1249 \mathrm{~cm}^{-1}$, identificam-se características das vibrações de estiramento das ligações C-O, grupo ésteres. 
São apresentadas as principais bandas de absorção da luz infravermelha dos comprimentos de onda, no espectro do sobrenadante da granulometria Fundo (prato), por meio da tabela 4.25 .

Tabela 4.25 - Bandas referenciadas na granulometria Fundo (prato).

\begin{tabular}{cc}
\hline Banda $\left(\mathbf{c m}^{-\mathbf{1}}\right)$ & Atribuição \\
\hline 3417 & Estiramento da ligação O-H \\
2929 & Estiramento da ligação Csp3 \\
1727 & Estiramento da ligação C=O \\
1606 & Estiramento da ligação C=C \\
1249 & Estiramento da ligação C-O \\
\hline
\end{tabular}

O material resina epóxi, foi submetido a análise por Infravermelho e o resultado obtido para neste ensaio é apresentado na Figuras 4.7. 


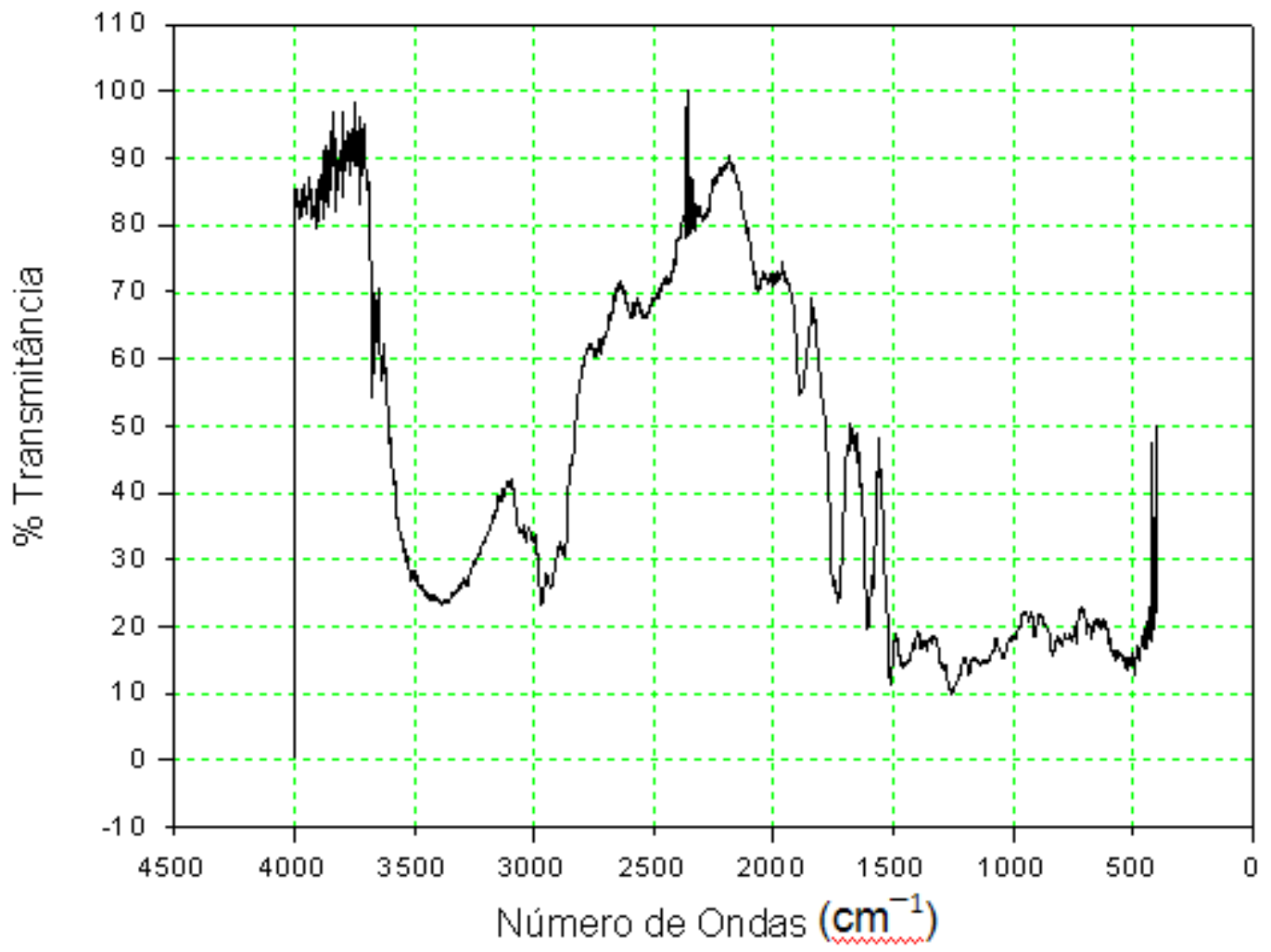

Figura 4.7 - Espectro de FT-IR da resina epóxi.

São apresentadas as principais bandas de absorção da luz infravermelha dos comprimentos de onda, no espectro da resina epóxi, por meio da tabela 4.26.

Tabela 4.26 - Bandas referenciadas no espectro da resina epóxi.

\begin{tabular}{|cc|}
\hline Banda $\left(\mathbf{c m}^{-\mathbf{1}} \mathbf{)}\right.$ & Atribuição \\
\hline 3372 & Estiramento da ligação O-H \\
\hline $3371,2967,2933,2875$ & Estiramento da ligação C-H de alifáticos \\
\hline 1889 & Estiramento da ligação C=O \\
\hline $1735,1608,1513$ & Estiramento da ligação C=C de anéis aromáticos \\
\hline 1457 & Deformação angular assimétrica do grupo CH3 \\
\hline 1363 & Deformação simétrica do grupo CH3 \\
\hline 1257,1186 & Deformação assimétrica da ligação Ar-O-R \\
\hline 1041 & Deformação simétrica da ligação Ar-O-R \\
\hline 912 & Ligações C-C contraem enquanto ambas as ligações C-O estiram em anéis epoxidicos \\
\hline 835 & Deformação de anéis aromáticos fora do plano \\
\hline 738 & Estiramento de anéis arômaticos monosubstituidos \\
\hline
\end{tabular}

Comparação dos dois espectros obtidos por espectroscopia no infravermelho, em relação à resina epóxi e o material sobrenadante da granulometria $60 \mathrm{Mesh}$, apresentada por meio da figura 4.8 . 


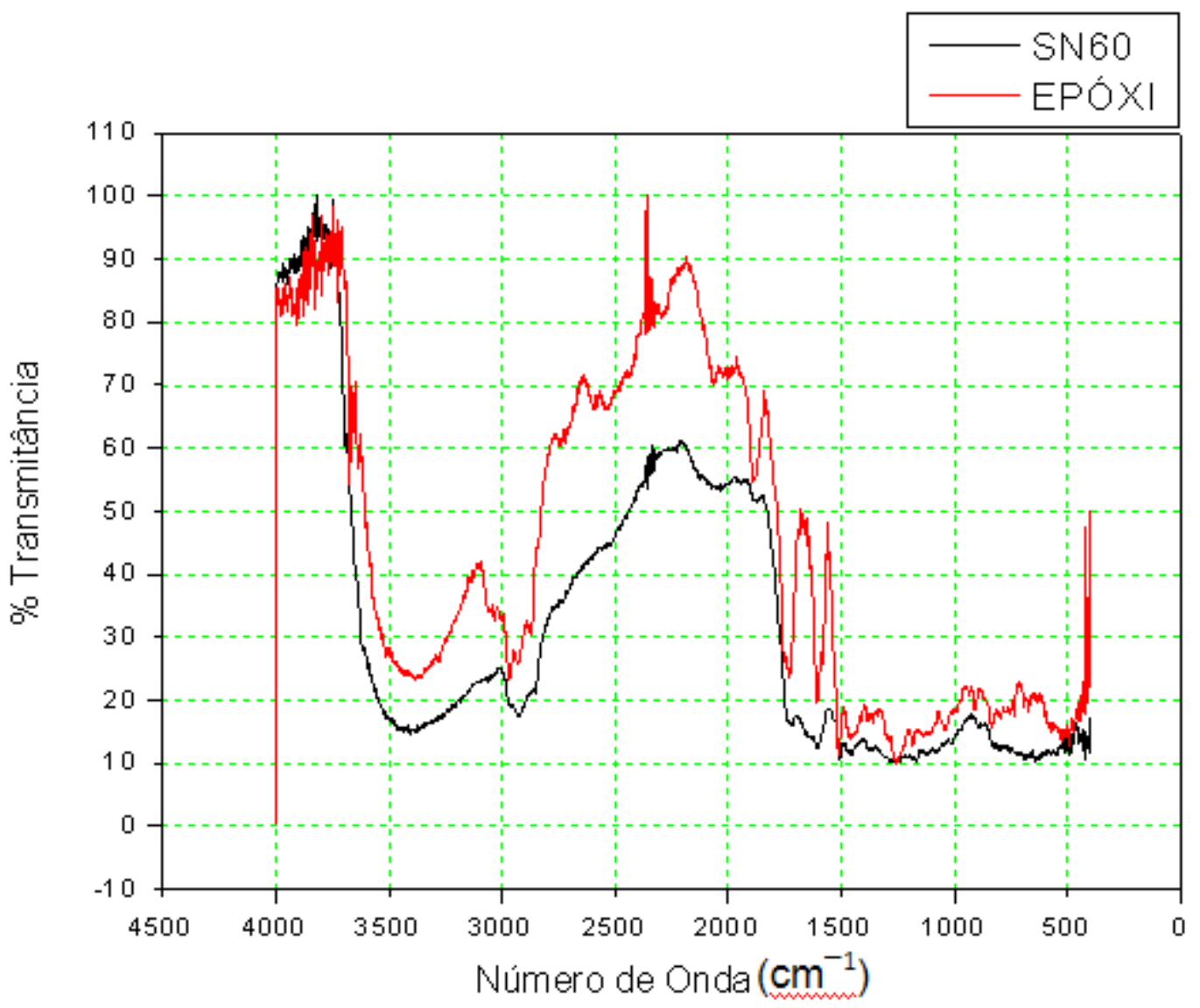

Figura 4.8 - Espectro de FTIR da resina epóxi e do material sobrenadante para a granulometria 60 Mesh.

Ao analisar o espectro de infravermelho do material, amostra extraída do sobrenadante da granulometria 60 Mesh e compará-lo ao espectro da resina epóxi, observa-se bandas semelhantes, esta combinação de bandas indica a presença dessas ligações e revela as respectivas freqüências de vibração, caracterizando que na estrutura química de ambos os espectros, existem ligações Glicosídicas, Grupos acetil e Grupos hidróxilo.

Comparação dos dois espectros obtidos por espectroscopia no infravermelho, em relação a resina epóxi e o material sobrenadante da granulometria 150 Mesh, apresentada por meio da figura 4.9 . 


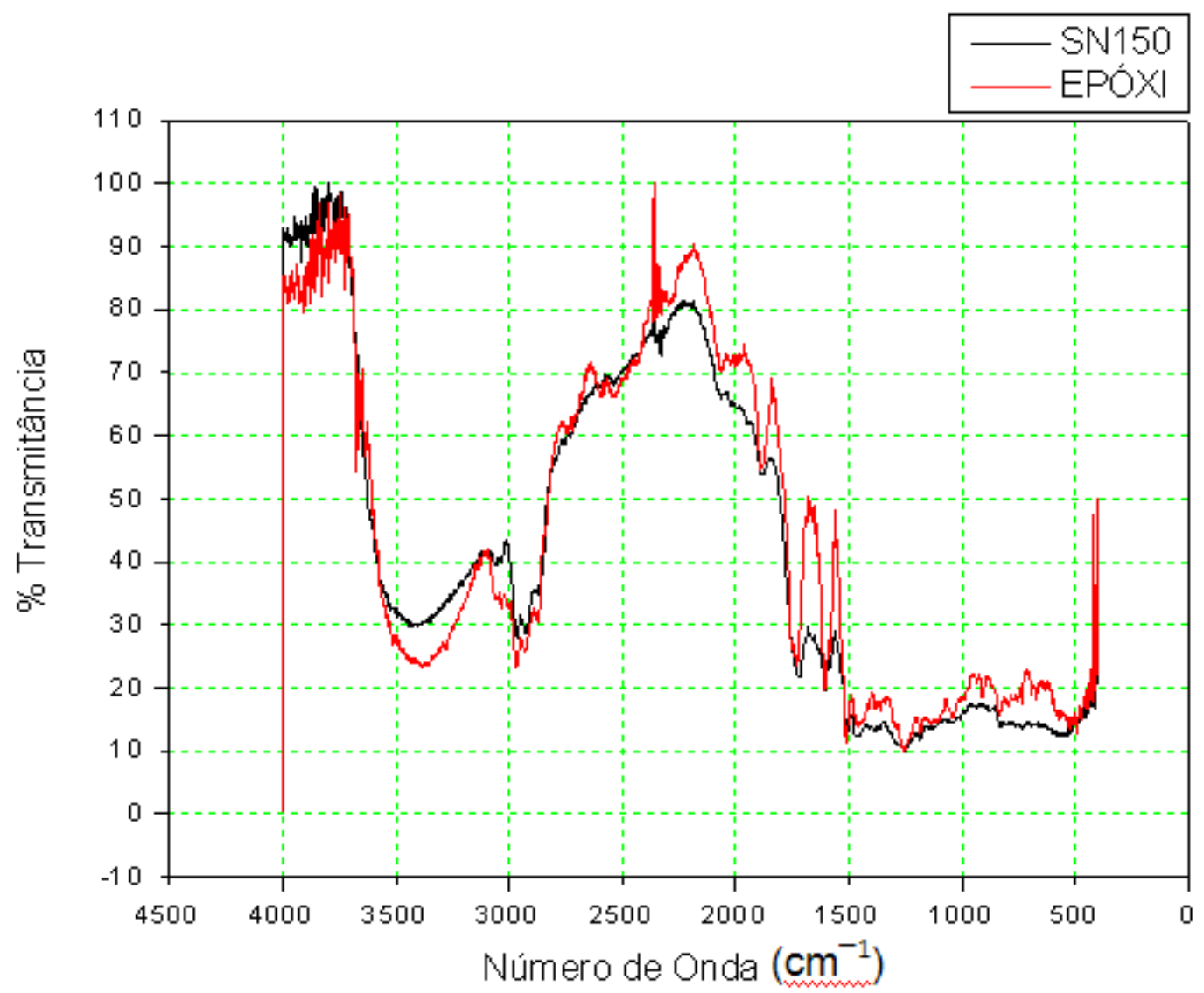

Figura 4.9 - Espectro de FTIR da resina epóxi e do material sobrenadante para a granulometria 150 Mesh.

Ao analisar o espectro de infravermelho do material, amostra extraída do sobrenadante da granulometria 150 Mesh e compará-lo ao espectro da resina epóxi, observa-se bandas semelhantes, esta combinação de bandas indica a presença dessas ligações e revela as respectivas freqüências de vibração, caracterizando que na estrutura química de ambos os espectros, existem ligações Glicosídicas, Grupos acetil e Grupos hidróxilo. 
Comparação dos dois espectros obtidos por espectroscopia no infravermelho, em relação a resina epóxi e o material sobrenadante da granulometria Fundo (prato), apresentada por meio da figura 4.10.

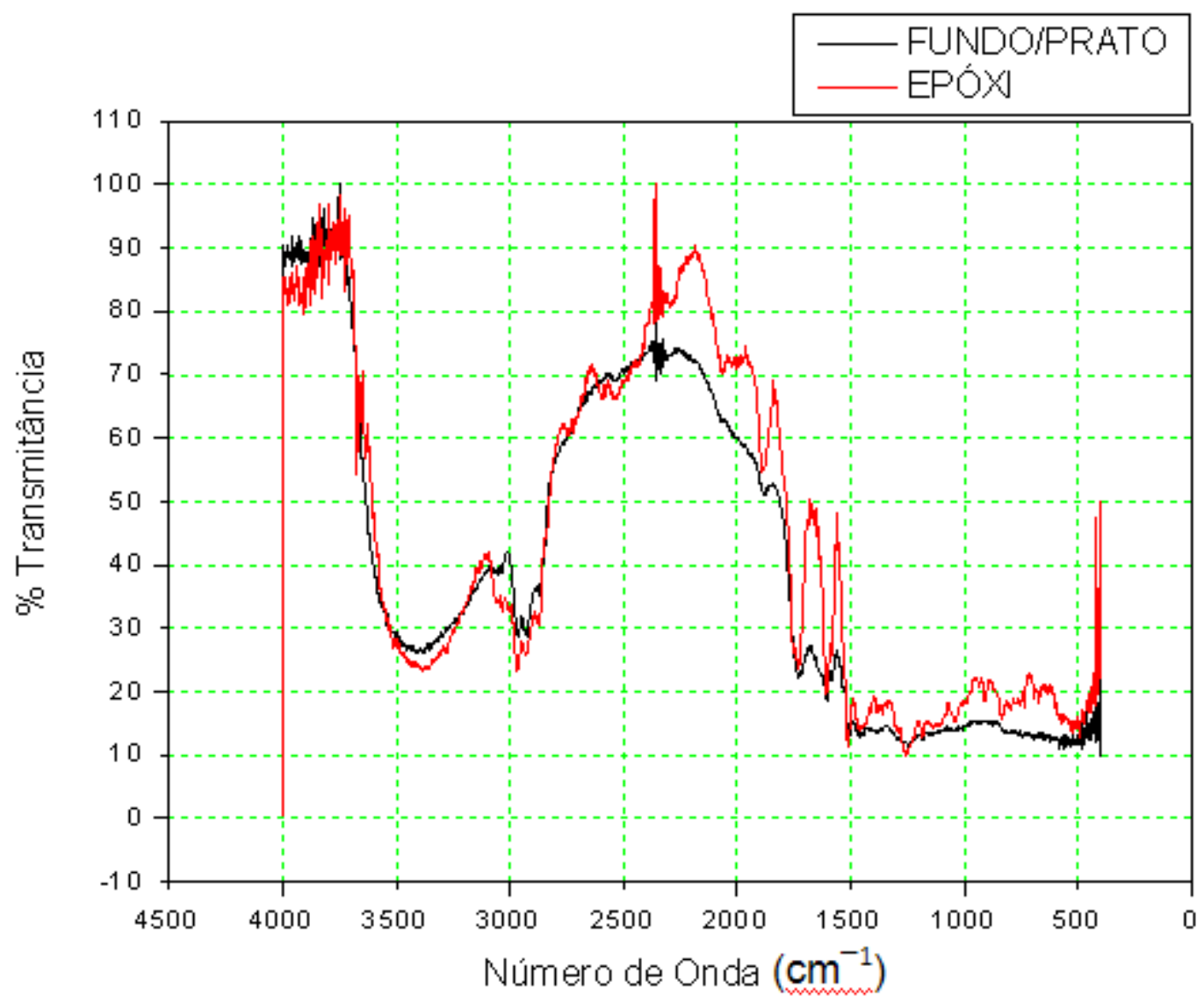

Figura 4.10 - Espectro de FTIR da resina epóxi e do material sobrenadante da granulometria Fundo (prato).

Ao analisar o espectro de infravermelho do material, amostra extraída do sobrenadante da granulometria Fundo (prato) e compará-lo ao espectro da resina epóxi, observa-se bandas semelhantes, esta combinação de bandas indica a presença dessas ligações e revela as respectivas freqüências de vibração, caracterizando que na estrutura química de ambos os espectros, existem ligações Glicosídicas, Grupos acetil e Grupos hidroxilo. 


\section{CONCLUSÕES}

Pode-se estabelecer as seguintes conclusões:

O moinho de martelo é adequado para a moagem do material das placas motherboard em diferentes granulometrias.

Verificou-se que o processo de separação de materiais metálicos e não metálicos, não é tão simples. O processo de separação física utilizando os separadores magnéticos e eletrostático não foi efetivo, pois, não permitiu a operação com partículas menores à granulometria 9 Mesh, devido à pulverização e descarte destas partículas no meio ambiente. Com a granulometria 9 Mesh, a presença da fração não metálica presente na amostra metálica é significativa, consequentemente perdendo a efetividade do processo de separação entre ambas as frações.

O processo de separação química por diferença de densidades utilizando o clorofórmio, permitiu a separação em sobrenadante (fração leve) os não metálicos e decantado (fração pesada), mas com a eficiência parcial. Verificou-se a presença de $\mathrm{Zn}, \mathrm{Ti}, \mathrm{Sb}, \mathrm{Pb}, \mathrm{Mn}, \mathrm{Fe}, \mathrm{Cu}, \mathrm{Ca}$, embora seja menores quantidades.

O processo de separação por diferença de densidades utilizando o Bromofórmio, permitiu a separação em sobrenadante (fração leve) os não metálicos e decantado (fração pesada) os metálicos, com maior eficiência, comparando com os resultados da separação por densidade utilizando a solução de clorofórmio.

Verificou-se a presença dos materiais metálicos em quantidades muito menores na fração leve (sobrenadante).

Ao comparar os resultados obtidos da fração leve (sobrenadante) do primeiro ensaio com os resultados obtidos do segundo ensaio, pode-se notar que o segundo ensaio apresentou resultados bastante positivos, pois apresentou uma redução das quantidades mássicas dos elementos químicos metálicos e houve um aumento das quantidades mássicas dos elementos químicos do tipo não metálicos presentes na fração leve (sobrenadante). Portanto foi possível fazer uma separação mais efetiva, 
dos materiais metálicos e não metálicos, isto se deve a uma maior desagregação do material, com a utilização do moinho de bolas (remoagem).

Espectroscopia no Infravermelho permitiu identificar a presença e a composição química de amostras poliméricas, ao analisar os espectros obtidos como resultados das três granulometrias 60; 150 Mesh e Fundo (prato), verificando grande incidência das bandas em relação à resina epóxi. 


\section{REFERÊNCIAS BIBLIOGRÁFICAS}

AGARWAL R., Computer Myths: The Story of Scrap, December 2005, (also published in "Southern Initiatives, Journal for Sustainable Development, Vol I, Issue III, 2005), p.2.

ANDRADE, R., BIZZO, W.A., Caracterização de placas de circuito impresso de computadores como resíduo sólido, Universidade Estadual de Campinas Unicamp, 2002, p.34.

ANDRADE, R., ANDRADE, V.F, BIZZO, W.A., Caracterização de placas de circuito impresso de computadores para reciclagem e recuperação energética, Universidade Estadual de Campinas - Unicamp, 2010, p.2.

ASSEMBLEIA LEGISLATIVA DO ESTADO DE SÃO PAULO - (ALESP, 2009), Departamento de Documentação e Informação, LEI № 13.576, DE 6 DE JULHO DE 2009, normas e procedimentos para a reciclagem, gerenciamento e destinação final de lixo tecnológico, Disponível em: <http://www.al.sp.gov.br>, Acesso em 28 maio 2012.

ASSEMBLEIA LEGISLATIVA DO ESTADO DO PARANÁ - (ALEP, 1999), Departamento de Documentação e Informação, LEI № 12.493, DE 22 DE JANEIRO DE 1999, Lei de resíduos sólidos, Disponível em: < http://www.cidadao.pr.gov.br>, Acesso em 28 maio 2012.

ASSOCIAÇÃO BRASILEIRA DA INDÚSTRIA ELÉTRICA E ELETRÔNICA - ABINEE. Comportamento da indústria eletroeletrônica em 2009 e previsões para 2010, 2009. Disponível em: <http://www.abinee.org.br/noticias/com2008.htm>. Acesso em 28 maio 2012.

ASSOCIAÇÃO BRASILEIRA DA INDÚSTRIA ELÉTRICA E ELETRÔNICA - ABINEE. Indicadores da industria elétrica e eletrônica, 2011. Disponível em: $<$ http://www.abinee.org.br/abinee/decon/decon15.htm>. Acesso em: 28 de maio 2012.

ASSOCIAÇÃO BRASILEIRA DA INDÚSTRIA ELÉTRICA E ELETRÔNICA - ABINEE. Indicadores da industria elétrica e eletrônica, 2013. Disponível em: 
$<\mathrm{http} / / /$ www.abinee.org.br/abinee/decon/decon15.htm>. Acesso em: 28 de março 2013.

ASSOCIAÇÃO BRASILEIRA DAS EMPRESAS DE LIMPEZA PÚBLICA E RESÍDUOS ESPECIAIS - ABRELPE, SILVA, C.R.V.F., Programa ABRELPE de Logística Reversa de Resíduos de Equipamentos EletroEletrônicos - REEE, 2010.

ASSOCIAÇÃO BRASILEIRA DE NORMAS TÉCNICAS. Resíduos Sólidos Classificação, Rio de Janeiro: ABNT, 2004 (ABNT NBR 10004:2004).

Basel Convention - (BASEL, 2009), Documento de Orientación para Mejorar la Preparación de los Informes Nacionales de las Partes en el Convenio de Basilea, Comité encargado de administrar el mecanismo para promover la aplicación y el cumplimiento del Convenio de Basilea, Setiembre de 2009, Disponível em: <http://www.basel.int>. Acesso em: 28 de maio 2012.

BIZZO, A.W. Ecopress, Jornal Express. 2007. Disponível em:

<http://www.ecopress.org.br/noticias+com+baixa+repercussao/equipamentos+velhos +representam+problema+novo+no+brasil>. Acesso em 5 abr. 2012.

BIZZO, A.W. (2007 a), Gestão de Resíduos e Gestão Ambiental da Indústria Eletro-eletrônica, abinee tec 2007, p.14. Disponível em: <http:// http://www.tec.abinee.org.br/2007/arquivos/s702.pdf >. Acesso em 28 de março 2013.

BONTURIM, E. Estudo das propriedades do óxido BSCF para aplicação como cátodo em células a combustível de óxido sólido de temperatura intermediária (ITSOFC). 2012. Dissertação (Mestrado) - Instituto de Pesquisas Energéticas e Nucleares, São Paulo.

BRYDSON, J.A., Plastics Materials (Seventh Edition), Copyright (c) 1999 Elsevier Ltd. All rights reserved ISBN: 978-0-7506-4132-6, cap. 26 - Epoxide Resins, 1999, p. 744-777.

DEAN, J.A. LANGE'S HANDBOOK OF CHEMISTRY, McGraw-Hill, 1999, Section 3. Inorganic Compounds, Table 3.2 Physical Constants of Inorganic Compounds, p. $3.13-3.60$. 
DIRECTIVA 2002/95/CE DO PARLAMENTO EUROPEU E DO CONSELHO, de 27 de Janeiro de 2003, relativa à restrição do uso de determinadas substâncias perigosas em equipamentos eléctricos e eletcrônicos (ROHS), (Jornal Oficial ํㅡ L 37 de $13 / 2 / 2003$, p. 19)

DIRECTIVA 2002/96/CE DO PARLAMENTO EUROPEU E DO CONSELHO, de 27 de Janeiro de 2003, relativa aos resíduos de equipamentos eléctricos e electrônicos (WEEE), (Jornal Oficial oㅡ L 37 de 13/2/2003, p. 24)

DYCKHOFF H.,LACKES R.,REESE J., Supply Chain Management and Reverse Logistics, ed. Springer, 2004, p. 163.

ESPINOZA, O., VILLAR, L., POSTIGO, T., VILLAVERDE, H., Diagnóstico del Manejo de los Residuos Electrónicos en el Perú, IPES - Promoción del Desarrollo Sostenible, Instituto Federal Suizo de Prueba de Materiales y Tecnologías (EMPA), 2008, p. 1-17-57-62.

EUGSTER, M., HONGJUN, F., E-Waste Assessment in P.R. China - A Case Study in Beijing, EMPA- Materials Science \& Technology, St.Gallen, Switzerland and Beijing, China, 2004, p. 6-11.

FINLAY, A., E-waste challenges in developing countries: South Africa case study, Association for Progressive Communications, 2005, p.17.

GONZÁLEZ, M. G., CABANELAS, J. C., BASELGA, J., Applications of FTIR on Epoxy Resins Identification, Monitoring the Curing Process, Phase Separation and Water Uptake, University Carlos III of Madrid, Spain, 2012, p.267.

GREENPEACE (2010). GUIDE TO GREENER ELECTRONICS, 8 $\mathbf{a}$ edition, Disponível em http://www.greenpeace.org/international/Global/international/publications/toxics/2010/ version16/Ranking\%20tables\%200ct\%202010-All\%20companies.pdf>. Acesso em 28 de março 2013. 
GUARNIERI, P., Nível de Formalização na Logística de Suprimentos da Indústria Automotiva - Análise do Caso das Montadoras, 2006, Dissertação, Universidade Tecnológica Federal do Paraná, p. 21-37-122.

GUARNIERI, P., Logística Reversa: em busca do equilíbrio econômico e ambiental, ed. Clube dos autores, 2011, p.56,62.

HOGAN, D.J., Dinâmica populacional e mudança ambiental: cenários para o desenvolvimento brasileiro- Campinas: Núcleo de Estudos de PopulaçãoNepo/Unicamp, ISBN 978-85-88258-09-9 , 2007,p. 19-21.

HILTY, L. M., Electronic waste - an emerging risk?, Technology and Society Laboratory, Empa, Swiss Federal Laboratories for Materials Testing and Research, St. Gallen, Switzerland, p. 431-435, 2005.

HISCHIER, R., WAGER, P., GAUGLHOFER, J., Does WEEE Recycling Make Sense From An Environmental perspective? - The Environmental impacts of the Swiss takeback and recycling systems for waste electrical and electronic equipment (WEEE), Environment Impact Assessment Review, St.Gallen, Switzerland, p. 535, 2005.

JAIN, P., CHOUDHARY, V., VARMA, I.K, Effect of structure on thermal behaviour of epoxy resins, Original Research Article, European Polymer Journal, Vol. 39, Issue 1, January 2003, p. 181-187.

KHETRIWAL D., Kraeuchi, P., Schwanninger, M., (2005), A comparison of electronic waste recyclingn in Switzerland and in India. Environmental Impact Assessment Review, 2005, p. $492-504$.

KUEHR R., WILLIIAMS E., Computers and the environment: understanding and managing their impacts, p. 29, 220, Springer, 2003. Disponível em:< http://books.google.com.br/books?id=t0Wgl5w1clsC\&pg=PR7\&lpg=PR7\&dq=Dr.+Kue hr\&source=bl\&ots=dlRJseMOkh\&sig=zuyFpxE8a4dylcr_lcpb4kYi3Pg\&hl=pt-

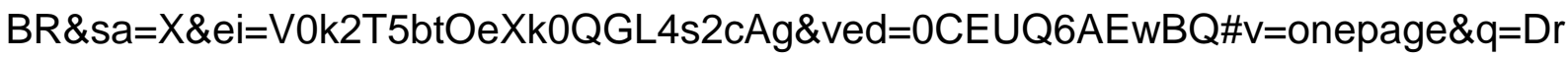
\%20Kuehr\&f=false $>$. Acesso em: 28 de março 2013.

LAU, K.,T., LUA, M., LIAOB,K., Improved mechanical properties of coiled carbon nanotubes reinforced epoxy nanocomposites, Department of Mechanical 
Engineering, The Hong Kong Polytechnic University, Hung Hom, Kowloon, Hong Kong, China School of Mechanical and Production Engineering, Nanyang Technological University, Singapore 639798, Singapore, Disponível em: <http://dx.doi.org/10.1016/j.compositesa.2005.09.019>, Acesso em 5 mai. 2013.

LOPES, W.A., FASCIO, M. , Esquema para interpretação de espectros de substâncias orgânicas na região do infravermelho, Instituto de Química, Universidade Federal da Bahia, Campus Universitário de Ondina, 40170-290 Salvador - BA, 2004, Disponível em: <http://www.scielo.br/scielo.php?pid=S010040422004000400025\&script=sci_arttext>. Acesso em 5 mai. 2013.

LUZ, A. B. da, COSTA, L. S. N. e POSSA, M. V. ALMEIDA, S.L.M. de, Tratamento de Minérios. CETEM/CNPq. P. 155,174, 187-200, 332-258, 1995.

MINISTÉRIO DO DESENVOLVIMENTO, INDÚSTRIA E COMÉRCIO EXTERIOR (MDIC, 2011), Grupo de Trabalho Temático - GTT Eletroeletrônicos, BRASIL. Disponível em: $<$ http://www.mdic.gov.br/sitio/interna/interna.php?area=2\&menu=3307>. Acesso em: 28 de maio 2012.

MINISTÉRIO DO MEIO AMBIENTE, Conselho Nacional de Meio Ambiente - (MMA, 2010), Indicadores de Geração de Resíduos Sólidos nas Capitais, BRASIL. Disponível em: <http://www.mma.gov.br/estruturas/219/_arquivos/texto_residuos_solidos_urbanos_2 010_219.pdf>. Acesso em: 28 de maio 2012.

MINISTÉRIO DA SAÚDE - (SAUDE, 2011), PORTARIA No- 2.914, DE 12 DE DEZEMBRO DE 2011, Dispõe sobre os procedimentos de controle e de vigilância da qualidade da água para consumo humano e seu padrão de potabilidade, BRASIL, DIARIO OFICIAL DA UNIÃO, № 239, 14/12/2011, p.39, Disponível em: $<$ http://www.in.gov.br/visualiza/index.jsp?data=14/12/2011\&jornal=1\&pagina=39\&total Arquivos=192>. Acesso em: 28 de maio 2012. 
MILLER, G., VP of Technology, Macquarie Equipment Finance, Strategic Advisory - Desktop Refresh Cycles: The view from post-2009; JULY 2010, P3. Disponível em: <http://www.rts.com/docs/Strategic\%20Advisory\%20-

\%20Desktop\%20Refresh\%20Cycles.pdf > Acesso em: 28 de março 2013.

MORAES, V.T., Recuperação de metais a partir do processamento mecânico e hidrometalurgico de placas de circuito impressos de celulares obsoletos, 2011, Tese (Doutorado) - Universidade de São Paulo.

NEWLANDS D.,HOOPER M.J, The global business handbook: the eight dimensions of international management, ed. MPG Books Ltd., 2009, p. 159.

NNOROM, I. C., OSIBANJO, O., Overview of electronic waste (e-waste) management practices and legislations, and their poor applications in the developing countries, Resoucers, Conservation and Recycling, v. 52, p. 843-858, 2008.

ORGANISATION FOR ECONOMIC AND DEVELOPMENT - (OECD, 2010), Critical Metals and Mobile Devices - A Sustainable Materials Management Case Study, OECD GLOBAL FORUM ON ENVIRONMENT Focusing on SUSTAINABLE MATERIALS MANAGEMENT, p. 35, 2010.

OTT, D., Gestión de Residuos Electrónicos en Colombia - Diagnóstico de Computadores y Teléfonos Celulares, Centro Nacional de Producción Más Limpia, Instituto Federal Suizo de la Prueba e Investigación de Materiales y Tecnologías, p. 45, 2008.

PALLONE, S., Resíduo eletrônico: redução, reutilização, reciclagem e recuperação. Revista Eletrônica de Jornalismo Científico, 2008. Disponivel em: http://www.comciencia.br/comciencia/?section=8\&edicao=32\&id=379. Acesso em: 28 de março 2013.

Política Nacional de Resíduos Sólidos. Disponível em: <http://www.planalto.gov.br/ccivil_03/_Ato2007-2010/2010/Lei/L12305.htm> Acesso em: 20 Ago. 2011 
RON, A., PENEV, K., Disassembly and recycling of electronic consumer products: an overview, Manufacturing Technology Group, Faculty of Industrial Engineering and Management Science, Eindhoven University of Technology, The Netherlands, v.15, № 6, p. 363-374, 1995.

Salinas, A.C., Material informático y contaminación medioambiental, 2008, p.3., revisión 2.5 - 15/4/2008. Disponível em:

<http://www.xtec.cat/ acastan/textos/Contaminacion\%20y\%20material\%20informatic o.pdf>. Acesso em: 28 de março 2013.

SECRETARIA DO MEIO AMBIENTE - (SMA, 2011), Resolução SMA no 38/2011, Nota de Esclarecimento $\mathrm{n}^{\circ}$ 2, SÃO PAULO, 2011, p.731-736, Disponível em: <http://www.ambiente.sp.gov.br/wp/residuossolidos/>. Acesso em: 28 de maio 2012.

SILAEX QUÍMICA LTDA. - "Ficha técnica". Disponível em: < http://www.silaex.com.br/epoxi.htm>. Acesso em 5 mai. 2013.

STOCK, J.R., Development and implementation of reverse logistics programs, Oak Brook, IL: Council of Logistics Management, 1998.

TOWNSEND, T.G., JANG, Y., KOL, J.H., PEARSON, B., SPALVINS, E., WADANAMBIL, L., Assessment of True Impacts of E-Waste Disposal in Florida, Annual Report, University System of Florida, p. 8, 2003.

UFPA (2013). Espectroscopia na região infravermelho, capitulo 8, Solomons, T.W. Graham; Fryhle, c.b. quimica organica I, 8ํ ED, Rio de Janeiro,LTC, 2005,p.136,137, Disponível em <http://www2.ufpa.br/quimdist/livro_novo/quimica_organica_teorica/cap\%208\%20\%209.pdf >. Acesso em 28 de março 2013.

UNEP - United Nations Environment Programme - Sustainable Innovation and Technology Transfer Industrial Sector Studies - Recycling From E-Waste to Resources, p. 58-65, jul 2009. 
VEHLOW, J., BERGFRLDT, B., JAY, K., SEIFERT, H., WANKE, T., Thermal treatment of electrical and electronic waste plastics, Waste Management \& Research, V.18, p. 1-133-137, 2000.

VIANNA, Daniela. Resíduos hi-tech: uma bomba-relógio ambiental. Equipamentos velhos representam problema novo no Brasil. Portal do Instituto Carbono Brasil, 15/5/2007. Disponível em:< http://www.institutocarbonobrasil.org.br/noticias6/noticia=175157 >. Acesso em: 28 de março 2013.

WIDMER, R., LOMBARD, R., A report of the Swiss global e-waste programme Knowledge Partnerships in e-Waste Recycling - e-Waste Assessment in South Africa, EMPA- Materials Science \& Technology, St.Gallen, Switzerland, p. 22/41-24/41, 2005.

WIDMER, R., HEIDI O.K., DEEPALI, S.K.,MAX S., HEINZ,B., Global perspectives on ewaste, Environment Impact Assessment Review, St.Gallen, Switzerland, p. 436-458, 2005.

ZHANG, S. FORSSBERG, E. Intelligent liberation and classification of electronic scrap. Powder Technology. V. 105, p. 295-301, 1999.

ZUMBUEHL D., Mass Flow Assessment (MFA) and Assessment of Recycling Strategies for Cathode Ray Tubes (CRTS) for the Cape Metropolitan Area (CMA), South Africa, ETH-Empa, p. 10-12, 2006. 


\section{PUBLICAÇÕES}

Artigos completos publicados em anais e congressos

1. O. L. F. Junior; R. A. Vargas; M. Andreoli; J. R. Martinelli; E. S. M. Seo; LIXO ELETRÔNICO: DESENVOLVIMENTO DE PROCESSO DE RECICLAGEM E CARACTERIZACCÃO QUÍMICA DE PLACA DE CIRCUITO

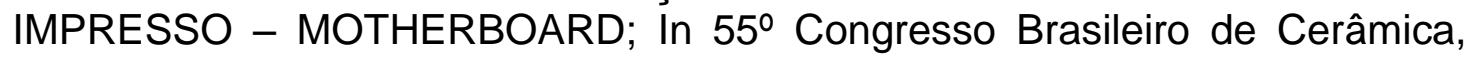
2011, Porto de Galinhas. Anais do 55ํㅡㄹ Congresso Brasileiro de Cerâmica ABCeram,2011. 